University of Louisville

ThinkIR: The University of Louisville's Institutional Repository

Electronic Theses and Dissertations

$12-2003$

\title{
James Wilson : progressive constitutionalist.
}

Bradley Jay Caffee 1972-

University of Louisville

Follow this and additional works at: https://ir.library.louisville.edu/etd

\section{Recommended Citation}

Caffee, Bradley Jay 1972-, "James Wilson : progressive constitutionalist." (2003). Electronic Theses and Dissertations. Paper 194.

https://doi.org/10.18297/etd/194

This Master's Thesis is brought to you for free and open access by ThinkIR: The University of Louisville's Institutional Repository. It has been accepted for inclusion in Electronic Theses and Dissertations by an authorized administrator of ThinkIR: The University of Louisville's Institutional Repository. This title appears here courtesy of the author, who has retained all other copyrights. For more information, please contact thinkir@louisville.edu. 
JAMES WILSON: PROGRESSIVE CONSTITUTIONALIST

By

Bradley Jay Caffee

B.A., Indiana University South East, 2001

\begin{abstract}
A Master's Thesis
Submitted to the Faculty of the Graduate School of the University of Louisville in Partial Fulfillment of the Requirements for a Degree of
\end{abstract}

Master of Arts in History

Department of History University of Louisville

Louisville, Kentucky

December, 2003 
Copyright 2003 by Bradley Jay Caffee

All rights reserved 


\title{
JAMES WILSON: PROGRESSIVE CONSTITUTIONALIST
}

\author{
By \\ Bradley Jay Caffee \\ A Master's Thesis Approved on
}

October 29, 2003

By the following Master's Thesis Committee:

Thesis Director 


\section{DEDICATION}

Without the sacrifices of my dear mother

Norna B. Caffee and beloved wife Robin Deckard-Caffee the completion of this thesis would not have been possible.

I dedicate this work to them. 


\section{ACKNOWLEDGMENTS}

There are numerous persons, without whose encouragement, comfort and aid I would have never finished this master's thesis. Listing all of them would take more pages than ought to be used. I must acknowledge my debt to Dr. Glenn Crothers who set me on the path of studying history, seemingly long ago, as an undergraduate at Indiana University South-East. And I would like to thank Dr. Wayne Lee for his challenging insights throughout my graduate studies at the University of Louisville. I am also grateful to Dr. Paul Weber for serving as the political scientist on my thesis committee. Above all, however, I must thank Dr. Thomas Mackey who put forth a tireless energy in keeping me on course. It may be added that I was never disappointed by following his good judgment. 


\section{ABSTRACT \\ JAMES WILSON: PROGRESSIVE CONSTITUTIONALIST \\ Bradley Jay Caffee}

December, 2003

This essay is a biography and ideological interpretation of James Wilson. Wilson was an important member of the Revolutionary generation whom historians and political theorists too often overlook. Moving from the rise of historical interest in Wilson and reasons why Wilson deserves study, this essay tells the story of Wilson's ideological development from the opposition Whig struggles of the 1760 s until his law lectures in 1790 and 1791 . Originally willing to accept Lockean ideas of contractualism in the British constitution he, like many Americans, rejected such contractualism during the Revolution in favor of an un-transferrable popular sovereignty that could only convey instrumental powers. The American constitutions were instruments of the People, not contracts. The purpose of this essay is to demonstrate that Wilson's understanding of popular sovereignty, instrumentalism and, ultimately, the 1787 federal Constitution, was couched in a progressive vision of civil society. For Wilson, such concepts were not clever manipulations used to establish power and conservatism in government, but rather, appreciable discoveries drawn from the American experience. 
TABLE OF CONTENTS

PAGE

ACKNOWLEDGMENTS iv

ABSTRACT

CHAPTER

I. WILSON AT THE BEGINNING OF THE TWENTY-FIRST CENTURY .................1

II. FROM OPPOSITION WHIG TO REVOLUTIONARY …........................................

III. WILSON: EVOLVING DEMOCRAT OR CONSPIRATORIAL ELITIST?.............61

IV. WILSON THE CONTINENTALIST AND THE ARTICLES …………..................79

V. WILSON AT THE 1787 CONSTITUTIONAL CONVENTION ............................94

VI. WILSON AND THE TWO NEW CONSTITUTIONS ….....................................126

VII. THE PROGRESSIVE CONSTITUTIONAL DOCTRINE ...................................142

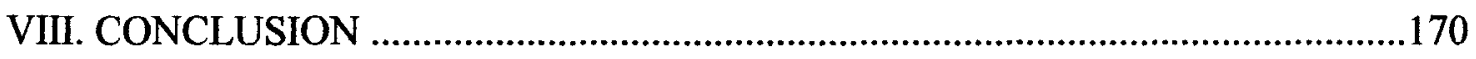

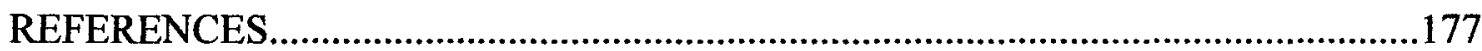

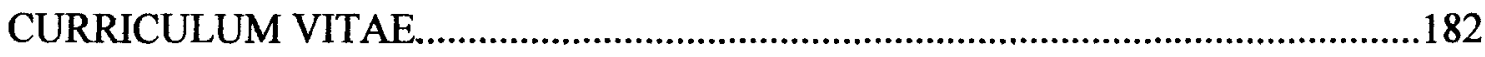




\section{CHAPTER I}

\section{WILSON AT THE BEGINNING OF THE TWENTY-FIRST CENTURY}

A progressive State is necessary to the Happiness and Perfection of Man. Whatever attainments may be already possessed, attainments still higher ought to be pursued. It is our Duty, therefore, to press forward, and to make increasing Advances in every Thing that can support, improve, refine and embellish Society. $\quad \sim$ James Wilson, 1788

In 1998, the historians Anthony Molho and Gordon S. Wood sounded a pessimistic chord concerning both the state of early American studies and the place of the United States in the contemporary world. Molho and Wood thought that American selfperception and historic interest were concurrently experiencing a diminution, arguing that the lack of interest in early American history among students had a direct connection to a more general disillusionment about the American destiny. They linked the American sense of importance to a sense of exceptionalism arguing that American exceptionalism was on the wane. ${ }^{1}$ But Molho's and Wood’s analysis can be questioned. Historian Daniel T. Rodgers, though in agreement with Molho and Wood, admitted that uniqueness is distinct from exceptionalism. Every nation on Earth can claim some uniqueness, but exceptionalism is a belief in a culturally inherent immunity to the more general currents of history. ${ }^{2}$ It is questionable if exceptionalism was ever that important to the American psyche, given that uniqueness of any sort may be sufficient to suggest a global mission,

\footnotetext{
${ }^{1}$ Anthony Molho and Gordon S. Wood, "Introduction” in Imagined Histories: American Historians Interpret the Past, ed. Anthony Molho and Gordon S. Wood (Princeton: Princeton University Press, 1998), 3-16.

${ }^{2}$ Daniel T. Rodgers, “Exceptionalism” in Imagined Histories ed. Molho and Wood, 21-22.
} 
all immunities to history aside.

Nonetheless, Molho and Wood's implication may be right that Americans are coming to question exactly what their mission in history is, just as they are coming to reassess the role of the United States in the community of nations. Though interest in early American history was declining in the late 1990s the decline may have been more due to the siren's call of the dot-com boom than a growing pessimism in the American destiny. ${ }^{3}$ In any case, given that America faces a possible reconfiguration in its own vision, it is imperative that Americans understand who they are, and what previous generations hoped they would be. Therefore, the study of history, particularly the American Revolution, is perhaps more important than ever and it is unfortunate that many potential students have lost interest.

This essay focuses on the life and intellect of one, key participant in the American Revolution, James Wilson. Interest in Wilson has steadily increased over the last forty years because a greater focus on ideology among historians of early America has made his ideologically astute orations and law lectures more valued.

A Scottish immigrant, Wilson quickly climbed the social ladder of colonial Pennsylvania and proved to be a dedicated opposition Whig both before and after the American decision to embrace independence. Broadly acknowledged in his own day to be one of the best educated and most insightful lawyers in the fledgling United States, James Wilson played a central role in the 1787 federal convention. He spoke more in the convention than any other single delegate after Rufus King, and his influence in the convention was second only to James Madison’s. ${ }^{4}$ Wilson brilliantly defended the

\footnotetext{
3 Molho and Wood, “Introduction” in Imagined Histories, ed. Molho and Wood, 16.

${ }^{4}$ Robert Green McCloskey, “Introduction” in The Works of James Wilson, Vol. I, James Wilson, ed.
} 
proposed Constitution in Pennsylvania's ratifying convention, constructing arguments that would inform Federalists in later ratifying contests. He remained an ardent Federalist for the remaining decade of his life and President George Washington appointed him to the Supreme Court, where he became one of its founding members. ${ }^{5}$

Wilson accepted the idea of un-transferable popular sovereignty as it arose from the Revolution, remaining perpetually loyal to broad and equitable representation of the People in government. What is demonstrated in Wilson's thought on the Constitution and its relationship to the people is a philosophy of sovereignty that was uniquely American, at least in application, and was neither Lockean or Hobbsean in origin. To make such a claim is not to say that Wilson, or any of the other Founders and their Revolution were impervious to the currents of history -- they were not examples of American exceptionalism themselves. Heavily influenced by previous European thought and history, they grasped at various threads of thought, winding them together into a new and unique synthesis. ${ }^{6}$ But the Founders were not always in perfect agreement, and Wilson certainly varied in his thought from the majority of his colleagues on certain points while agreeing on others.

Wilson, in both the Pennsylvania ratification convention and his later law lectures at the University of Pennsylvania, rejected the idea of the Constitution as a contract. For Wilson, the Constitution, a document that he played a central role in framing, was

Robert Green McCloskey (Cambridge: The Belknap Press of Harvard University Press, 1967), 1-6.

${ }^{5}$ Ibid., 28-29.

${ }^{6}$ A central assumption of the influential neo-Whig interpretation of the American revolutionary generation is that they were heavily influenced by European political thought, both common-place and radical. It was certainly Jean-Marc Pascal's focus when dealing with James Wilson. See Bernard Bailyn, Ideological Origins of the American Revolution (Cambridge: The Belknap Press of Harvard University Press, 1967); Jack P. Greene, The Intellectual Heritage of the Constitutional Era: The Delegates' Library (Philadelphia: The Library Company of Philadelphia, 1986; Gordon S. Wood, The Creation of the American Republic, 1776-1787 (Chapel Hill: The University of North Carolina Press, 1969); Jean-Marc Pascal, The Political 
essentially an instrument of the "people at large" rather than a contract between them and a set of governors. ${ }^{7}$ Its purpose was not only to secure liberty for Americans but to lay the foundation of future civil and moral progress. ${ }^{8}$ This essay argues that Wilson's adherence to the sovereignty of the people and the legal instrumentality in constitutionalism was intimately connected to a belief in a human right to perpetual, selfinitiated progress and the duty of government to facilitate that progress. In short, Wilson was an eighteenth century progressive.

The significance of James Wilson may seem a strange claim to some because he has by no means received the same attention as several others such as Thomas Jefferson, George Washington, James Madison and Alexander Hamilton, to name but a few. Yet, any in-depth reading of Madison's Notes on the Debates in the Federal Convention, should convince the reader rather quickly of Wilson's importance, as well as his devout faith in popular government. ${ }^{9}$ Similarly, reading Wilson's law lectures, as unfinished as they are, suggests why Wilson's colleagues held his legal understanding in such high esteem. ${ }^{10}$ Nonetheless, only two standard biographies, each in a single volume, have been written on Wilson. The first by historian Andrew Bennett in 1928 was a sparse account of events in Wilson's life. ${ }^{11}$ The second, far better and more involved work of scholarship was written by Charles Page Smith and published in 1956. Smith’s monograph filled out the details of Wilson's life very well, but paid scant attention to the

Ideas of James Wilson, 1742-1798 (New York: Garland Publishing, Inc., 1991).

\footnotetext{
${ }^{7}$ George M. Dennison, “The 'Revolution Principle': Ideology and Constitutionalism in the Thought of James Wilson” The Review of Politics Vol. 39 (1977), 174-179; Pascal, Political Ideas, 29-44.

${ }^{8}$ Mark David Hall, The Political and Legal Philosophy of James Wilson, 1742-1798 (Columbia: University of Missouri Press, 1997), 179-186; Pascal, Political Ideas, 263-268 and 332-334.

${ }^{9}$ See James Madison, Notes of the Debates in the Federal Convention of 1787 (New York: W.W. Norton \& Company, 1966).

${ }^{10}$ See Wilson, Works, Volumes I and II, ed. McCloskey.
} 
details of Wilson's thought. ${ }^{12}$ However, Wilson's law lectures, with some of his core orations included, have been published four times. ${ }^{13}$

Part of the reason that Wilson has not received the same attention as other Founders may be that he died in ignominy. He had vastly over-invested in pyramid schemes in western lands. Even before the bottom fell out of the market in the late 1790s, Wilson was financially in over his head, having to take out loans just to keep afloat. $^{14}$ It was probably his financial difficulties that caused Washington to appoint him as an Associate Justice of the Supreme Court, rather than Chief Justice. The fact that he was not appointed Chief Justice surprised many. When the pyramid schemes in western lands collapsed, Wilson was ruined. As the historian Charles Page Smith expressed the situation, Wilson could barely clothe his family when he fled to North Carolina to escape his creditors. The Associate Justice was eventually jailed there but was bailed out by his son, Bird Wilson, only to die an untimely death in a hotel room, without a cent to his name. $^{15}$

Another reason that Wilson has not received as much attention as he deserves is that Wilson experienced no achievements that normally draw amateur historians and therefore the more general book-buying public. Wilson was not a President, a pithy inventor, a fiery polemicist, a doomed foil for Thomas Jefferson, or a transformative jurist in the American tradition of law -- though the later was not from a lack of attempt

\footnotetext{
${ }^{11}$ Hall, Political and Legal Philosophy, 3.

12 Hall, Political and Legal Philosophy, 3; See Charles Page Smith, James Wilson: Founding Father, 17421798 (Chapel Hill: University of North Carolina Press, 1956).

${ }^{13}$ These editions include one published by James Wilson's son, Bird Wilson in 1804. Also see James Wilson Selected Political Essays of James Wilson, ed. Randolph G. Adams (New York: Alfred A. Knopf, 1930); James Wilson The Works of James Wilson, Volumes I and II, ed. James DeWitt Andrews (Chicago: Callaghan and Company, 1896); Wilson, Works, Volumes I and II, ed. McCloskey.

${ }^{14}$ Smith, James Wilson, 304-306, 369-375.
} 
on Wilson’s part. For example, Wilson's influence was central in the Supreme Court's 1798 ruling in Chisholm vs. Georgia. ${ }^{16}$ The state of Georgia claimed that the citizen of another state could not sue it because it was a sovereign. The Court, led by Wilson, rejected Georgia’s argument maintaining that the states were not sovereign, rather the people of the United States were sovereign. The people had established the federal government to exist over the state governments through ratification. And the federal judiciary was, by design, established to resolve interstate disputes between parties. Therefore, Georgia could be sued in a federal court. The nationalistic and judicial implications of the ruling were far reaching and probably would have secured Wilson's place in juridical history as a pivotal Supreme Court justice. But the states reacted by ratifying the Eleventh Amendment prohibiting litigation by citizens against states within which they did not reside, blotting out the effect of the entire ruling. The day had been stolen from Wilson, and the foundation was laid instead for John Marshall with his unique approach to federalism. ${ }^{17}$

Historian Robert Green McCloskey has pointed out yet another reason that Wilson has been often overlooked. Wilson was awful as a correspondent; he would only write occasionally. Friends often complained that he let too much time pass before writing. As a result, very little Wilson correspondence has survived, particularly when compared to that of contemporaries like Madison or Jefferson. It is notoriously difficult,

\footnotetext{
${ }^{15}$ Ibid., 380-388.

${ }^{16}$ Chisolm vs. Georgia, 2 U.S (2 Dallas), 419-479 (1793).

17 Hall, Political and Legal Philosophy, 169-173; McCloskey, "Introduction” in Works, Vol. I, Wilson, 31; Pascal, Political Ideas, 276-279; Chisolm vs. Georgia, 2 U.S (2 Dallas), 419-479 (1793). For the approach of John Marshall see William E. Nelson, Marbury vs. Madison: The Origin and Legacy of Judicial Review (Lawrence: University Press of Kansas, 2000), 54-83.
} 
therefore, for historians to comprehend the personal Wilson. ${ }^{18}$

Nonetheless, some scholarship on Wilson has appeared and the literature has slowly accumulated, building up more quickly over the last forty years. Numerous articles and specialized monographs have focused on Wilson's nationalistic, legal and political thought. And historical opinions on Wilson, even the briefest, have generally been far from unkind. Even Charles A. Beard, the godfather of materialist interpretation in early American history, was compelled to note Wilson’s ideological integrity.

Beard's 1913 An Economic Interpretation of the Constitution of the United States was a reaction to better than one hundred years of Whig interpretation that was more patriotic than scholarly. Beard also reacted against the highly formalistic "Institutional" and "Imperialist” schools. The "Institutionalist” historians focused on the evolution of governmental institutions, while a sub-set of the "Institutionalists" developed, known as the "Imperialists," who saw the Revolution as an episode in the larger, trans-Atlantic British institution of Empire. Beard wanted to use new historical approaches pioneered in Europe that emphasized deterministic, material factors in the making of history. ${ }^{19}$

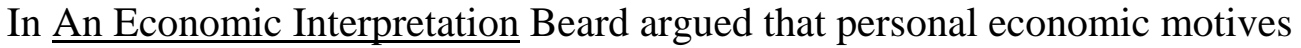
directed the Founders. The Constitution resulted from a need for economic security by the elites leaders of the Revolution, a security threatened by popular government in the states. Tension in the convention resulted from competing economic interests, with the holders of public securities on one side and holders of western lands on the other. Taking this position necessarily meant arguing or assuming that the Founders, for the most part,

\footnotetext{
${ }^{18}$ McCloskey, "Introduction” in Works, Vol. I, Wilson, 7.

${ }^{19}$ Forest McDonald, “A New Introduction” in An Economic Interpretation of the Constitution of the United States, Charles A. Beard (New York: The Free Press, 1986), ix-xii; John Phillip Reid, Constitutional History of the American Revolution Abridged Edition, (Madison: University of Wisconsin Press, 1995), x-
} 
did not mean what they said about cultural principles and political ideas such as liberty and popular sovereignty.

Yet when coming to Wilson, Beard said that he "was among the philosophers of the period who had seriously pondered on politics. He took a democratic view on several matters.” After citing some examples of Wilson's support for popular government, Beard added "He...opposed...property qualifications of voters.” This last point should have been a worrisome point for Beard, and yet he passed it by without qualification. Beard tried to make Wilson fit into his deterministic thesis by pointing to Wilson's support for a strong judiciary, reasoning that Wilson thought a strong judiciary sufficient to check the “democratic legislatures” of the states. ${ }^{20}$ Though Beard's interpretation of Wilson does not hold up to close analysis, as will become apparent in the later portion of this essay, what is interesting about it is that Beard was willing to take Wilson at his word -something he was not willing to do for many of the other Founders.

Equally interesting is what evidence Beard failed to use, particularly in regard to Wilson. James Wilson maintained a consistent ideological position throughout the constitutional convention that was both nationalistic and democratic, but he was also involved with an incident at the convention that would have supported Beard's general view of the Founders quite well. When small-state delegate Daniel Carroll of Massachusetts suggested that a clause be struck out, protecting the western lands of larger states from division and use without their consent, Wilson, a holder of western lands, reacted passionately. Wilson countered that a political society should not be "torn asunder without its own consent.” Luther Martin then implied that Wilson was guilty of

xi.

${ }^{20}$ Beard, An Economic Interpretation, 215-216. 
hypocrisy, saying that "he wished Mr. Wilson had thought a little sooner of the value of political bodies." Wilson had, before this exchange, forcefully rejected the claims of the small states that they required protection from the larger states through the perpetuation of equal representation. ${ }^{21}$ Though no reason exists to accept Martin's accusation as accurate, the episode would have served Beard well. Yet, in Beard's discussion of Wilson, it is never mentioned. One wonders if the omission involved a failure of research or an uncharacteristic respect for Wilson that made Beard hold back.

In any case, even if Beard had discussed the previous episode, his over all argument would have still been weak. What is amazing about the Beardian argument is not how easily it was pulled apart by revisionists in the 1950s and 60s, but how long it retained ascendancy. Beard's argument held sway over historical thinking about the federal constitution for most of the first half of the twentieth century. And it gave preeminence to materialistic interpretations of the whole Revolutionary era. One explanation put forward by historian Forrest McDonald for the fall of the Beardian thesis is that following World War II the number of historians began to increase and that, by the 1950s, primary records, and even secondary works, had become vastly more accessible to the body of historians. These changes, combined with the weakness of Beard's chief work made revision likely in the 1960s. ${ }^{22}$ The implication of McDonald's explanation then is that Beard's argument had been protected by fifty years of too few historians with too little access to primary sources.

During the same period that Beard's interpretation gained acceptance

\footnotetext{
${ }^{21}$ Calvin C. Jillson and Cecil L. Eubanks "The Political Structure of Constitution Making: The Federal Convention of 1787” American Journal of Political Science, 28 (August, 1984): 452-453; Madison, Federal Convention, 555-557.

${ }^{22}$ McDonald, “A New Introduction” in An Economic Interpretation, Beard, xxiii-xxvi.
} 
Progressivism became a force in American politics, and some historians interested in supporting the Progressive movement took an interest in Wilson. Such historians were particularly interested in Wilson's support for a powerful nationalistic government as well as his devotion to democratic principles. ${ }^{23}$ The legal historian Randolph C. Adams is an excellent example of this type of Wilson scholarship. He focused on Wilson's democratic and nationalistic thought, but more important for Adams was what Wilson had to say about international law. Adams, a supporter of a more proactive body of international law, showed how Wilson thought international law was possible without a superior governing body to administer it. Indeed, Adams implied, echoing Wilson, a strong and democratic international law would be a natural outgrowth of the fundamental principles of American politics. ${ }^{24}$

Another distinctive group of historians showed interest in Wilson during the first half of the twentieth century. Religious scholars took interest in Wilson's theology and epistemology and how the Founder connected that thought to his political understanding. Several articles and two monographs were produced by this group. ${ }^{25}$ Perhaps the most important historian in this group, for later Wilson scholars, was the historian Arnaud B. Leavelle. Leavelle introduced the idea that Wilson was heavily influenced by Scottish Common Sense thought. Leavelle outlined the link between common sense philosophy, as perpetuated by Thomas Reid, and Wilson's acceptance of concepts such as popular

\footnotetext{
${ }^{23}$ Hall, Political and Legal Philosophy, 2-3.

${ }^{24}$ Randolph C. Adams, “The Legal Theories of James Wilson” in University of Pennsylvania Law Review and American Law Register, 68 (June, 1920): 337-355.

${ }^{25}$ Hall, Political and Legal Philosophy, 3. Hall cited two monographs from the group: William F. Obering, The Philosophy of Law of James Wilson (Washington D.C.: Catholic University of America, 1938) and May G. O’Donnell, James Wilson and the Natural Law Basis of Positive Law (New York: Fordham University Press, 1937).
} 
consent, nationalism and judicial review. ${ }^{26}$ Late twentieth-century scholars still accepted that common sense had an influence on Wilson though they argued who in the tradition had the most influence. The historian Jean-Marc Pascal argued convincingly that Francis Hutchison had been a far greater influence on Wilson than Thomas Reid. ${ }^{27}$ Fifteen years later, Mark David Hall argued that though Hutchison’s influence was dominant, Reid's thinking was also important to Wilson. ${ }^{28}$ The common sense influence on Wilson's thought will be discussed in greater detail in Chapters 2 and 7.

When Leavelle wrote, economic and social historians with deterministic assumptions still dominated in academic histories of the Revolution, but that was about to change. In 1956, the historian Edmund S. Morgan spoke at a meeting of the Mississippi Valley Historical Association, calling for a general re-assessment of the Revolution. Morgan pointed out that interpretations of the Revolution throughout the first half of the twentieth century had generally called into question the sincerity of the Founding generation, and had pointedly attacked the older Whig interpretation. But these later revisions had serious holes from his point of view, giving numerous examples within the context of each school of interpretation. ${ }^{29}$ Particularly interesting to him was how many historians had argued that a conflict existed between human rights and property in the Revolution. To the contrary, Morgan pointed out that in the eighteenth century, "liberty and property rights were one and inseparable.” He went on to discuss how broadly land

\footnotetext{
${ }^{26}$ Arnaud B. Leavelle, “James Wilson and the Relation of the Scottish Metaphysics to American Political Thought” in Political Science Quarterly, 57 (September, 1942): 394-410.

${ }^{27}$ Pascal, Political Ideas, 59-92.

${ }^{28}$ Hall, Political and Legal Philosophy, 68-89.

${ }^{29}$ Edmund S. Morgan, “The American Revolution: Revisions in Need of Revising” in The American Revolution : Two Centuries of Interpretation ed. Edmund S. Morgan, (Englewood Cliffs: Prentice-Hall Inc., 1965), 166-179. Morgan refers to a school of social interpretation and a school of economic interpretation that this author has combined under the label "materialist." He also mentions other schools of
} 
was distributed in eighteenth-century Massachusetts, and accused his colleagues of using nineteenth and twentieth century paradigms to judge a very different eighteenth-century America. He ended declaring that "the Whig interpretation of the American Revolution may not be as dead as some historians would have us believe.”30

Even as Morgan called for a new interpretation, some historians were providing the first important answer to it. The first revisionism to effectively challenge the Beardians and other materialists (not all materialists held to Beard’s specific arguments) was the "liberal interpretation." This school, that tended to focus on the importance of John Locke, did not topple the predominance of the materialists but it played an important role. The liberal revisionists dared to take the Founders at their word and tried to make connections between the Revolution and the liberal tradition developing in England. These historians saw the Revolution as essentially conservative -- Lockean ideas became broadly accepted in British America because the colonies already lived in a very Lockean political reality within their respective colonies. When the Revolution became necessary, the colonists used Lockean, liberal principles to justify and guide their activity. $^{31}$ The colonists launched the independence movement, and fought its appended war attempting to preserve a liberal status quo, rather than produce a revolution in politics and society. Another important element of the liberal revision was that it offered an essentially ideological model. Contrary to the materialist school, which assumed that human history was primarily a reaction to material stimuli acting on individuals and groups, liberal revisionists emphasized the power of political culture to restrain or compel

thought that are less relevant to this essay and so have been omitted from the discussion.

${ }^{30}$ Morgan, “Revisions in Need of Revising,” 177.

${ }^{31}$ Daniel T. Rodgers, "Republicanism: the Career of a Concept” in The Journal of American History, 79 (June, 1992): 12-13. 
historic activity. $^{32}$

However, as historian Daniel T. Rodgers argued, the liberal re-interpretation had a central weakness in that it could not explain the revolutionary generation's anxieties or their internal conflict. Materialist historians were too happy to point out that if the revolutionary generation had been consistently dedicated to, and overwhelmingly motivated by the same rationalistic, Lockean political doctrine, then the internal strife that they had documented would not have occurred. The liberal revisionists had a difficult time explaining away the revolutionary generation’s in-fighting -- particularly when dealing with the eventual divide between Federalists and Republicans. ${ }^{33}$

It was within this environment that the historian Bernard Bailyn first published The Ideological Origins of the American Revolution. The implications of Bailyn's arguments have served as lightning rods for re-interpretation of the Revolutionary Era over the next thirty years. Looking at hundreds of pamphlets from the Revolutionary Era, Bailyn came to the conclusion that the Revolutionary and Founding generation had been heavily influenced by the anti-authoritarian literature of the Glorious Revolution and the opposition Whigs that followed. No single monolithic doctrine existed, but numerous political and social assumptions did, that together, created a distinct political culture for eighteenth century British Americans. It was an opposition Whig political culture, exported from England that informed the colonists, first in opposition to Parliament, and then in open rebellion against Parliament and the King.

Bailyn's interpretation was similar to the early attempt of the liberal revisionists in numerous ways. He saw the initial motivations of the Revolutionaries as essentially

\footnotetext{
32 Jillson and Eubanks, "The Political Structure of Constitution Making," 436-437.

33 Rodgers, “Career of a Concept," 14.
} 
ideological and conservative, and Bailyn operated on the presumption that, for the most part, the men who wrote the pamphlets that he studied meant what they were saying. The colonists did what they believed they had to do to protect their liberty, which was threatened by an aggressive and overreaching British Parliament. But the role of Locke was minimized in The Ideological Origins as was the importance of contract theory, and concepts of natural rights. Civil property rights as a guarantee of liberty, representation as a guarantee of property rights, and an abiding belief in, and anxious fear of the corruption of power, took central importance. ${ }^{34}$

Bailyn additionally argued that Whig principles radically transformed in the battle for American independence and the political experimentation that accompanied it. The Whig heritage was diverse, and as Americans tried to make sense of that heritage in their new situation, ideological fissures developed. ${ }^{35}$

It was on this foundation that what eventually became known as the republican consensus was built. Following The Ideological Origins, students of Bailyn began to publish influential books that supported, while extending and diversifying, Bailyn's original view. Like Bailyn, Gordon S. Wood argued in The Creation of the American Republic, 1776-1787 that opposition Whig thought had dominated the political culture of the Revolutionaries and that the struggle for independence forced transformations in that thought. Wood, however, gave additional emphasis to the importance of virtue, equality and antique models of civil society, pointing out the importance of republican Rome as an ideal vision. And he, perhaps inspired by the historian Cecelia M. Kenyon, ${ }^{36}$ gave

\footnotetext{
${ }^{34}$ See Bailyn, Ideological Origins.

${ }^{35}$ Bailyn, Ideological Origins, 272-319.

${ }^{36}$ See Cecelia M. Kenyon, "Republicanism and Radicalism in the American Revolution: An Old Fashioned Interpretation” William and Mary Quarterly, 3rd Series, 19 (April, 1962): 153-182. Kenyon was operating
} 
these convergent threads of political thought a name -- republicanism.

Republicanism was the chief driving and restraining force of the Revolution, and yet was itself transformed by the Revolution. But the greatest transformation that that ideology had undergone in the Revolutionary Era, came about with the creation and ratification of the federal Constitution of 1787. The men who desired the new Constitution had grown fearful that excessive democracy had grown up in the states, according to Wood, and sought a new, more aristocratic federal structure as a check to state democratization. Necessarily, Wood had to emphasize the ideological differences between “republicanism” and “democracy.” Implicitly, of course, Wood’s analysis was somewhat neo-Beardian, having to assume that, when coming to the Constitution, the revolutionaries had ceased saying what they meant, and viewing the chief struggle over the Constitution as a struggle between pro-democratic state and anti-democratic nationalistic forces. ${ }^{37}$ James Wilson offers a counter-point to this part of Wood's argument as will be seen in Chapter 5. In any case, the republican model embodied in the Constitution differed from classical republicanism in many of its political assumptions, according to Wood, and unintentionally laid the foundation for the future liberalization of society. $^{38}$

Three years after Wood published The Creation of the American Republic,

within the Lockean-centered liberal school of the period. Long before Bailyn's focus on Whig ideology, Kenyon used the term "republicanism" to describe the attitude of the Revolutionaries toward government following Independence in which they embraced pure republican forms of government. She thought that the Revolution began as a conservative reaction based on Lockean principles, but it developed into a radical movement based on the same principles afterward. It is an interesting foreshadowing of very similar arguments within the later republican interpretation.

${ }^{37}$ Wood, American Republic, 513-516.

${ }^{38}$ Ibid., 606-615. Also see Gordon S. Wood, The Radicalism of the American Revolution (New York: Vintage Books, 1991). In this later monograph, Wood focuses on the socio-political developments of the Revolution rather than the institutional and constitutional changes. Nonetheless, it may be considered an appendage to his earlier work. In Radicalism, Wood expands and develops his argument that an 
Pauline Maier published another influential book, From Resistance to Revolution. Maier focused on British American opposition to Parliament from 1765 to 1776. She argued that republican ideology was indeed important to the development of the colonial opposition, going into deeper detail about the opposition movement, and the civil unrest that it often produced, than had either Bailyn or Wood. ${ }^{39}$ Though Maier did not offer a discussion of the Constitutional Convention, her brief comments suggested a more optimistic view than Wood. She viewed the Constitution as a logical culmination of constitutional and political experimentation that began with the decision to embrace independence. $^{40}$

Another important tome was added to the republican interpretation with the publication in 1975 of The Machiavellian Moment by J.G.A. Pocock. Pocock argued that “country opposition” ideology guided the American Revolution, and had its cultural roots in the Renaissance political thought of the Florentine commune. It was an anti-corruption philosophy centered around concepts of civic virtue and a fear of societal decay. Florentine thought had been adopted by opposition Whigs in England who in turn inspired the thinking of the American Founders. The Revolution could be explained in terms of court versus country as could the eventual polarization of the Founders into Federalists and Republicans. Unlike Bailyn and his students, however, Pocock was not interested in how the experience of the Revolutionaries transformed Whig political assumptions, but was instead fascinated with continuity. Pocock focused on how opposition Whig thought (that he called "country ideology") was not fundamentally

unintended consequence of the Revolutionary era was the liberalization and commercialization of society.

${ }^{39}$ See Pauline Maier, From Resistance to Revolution: Colonial Radicals and the Development of American Opposition to Britain, 1765-1776 (New York: W.W. Norton \& Company, 1991).

${ }^{40}$ Ibid., 271-272. 
changed by the Revolution and even, he believed, still resided at the core of American civic religion well into the twentieth century. Pocock also drew a strict division between Whig thought and liberalism, wholly rejecting the importance of John Locke in any aspect of the Revolution. For Pocock, liberalism was a pointed antagonist of the Whig tradition. A circle quickly formed around Pocock in St. Louis that included historians such as Lance Banning and Andrew McCoy. ${ }^{41}$

According to the historian Daniel T. Rodgers, a rivalry developed between the St. Louis circle and Bailyn's old students, over the postwar history of republicanism in America. Nonetheless, a kind of consensus did eventually form between these groups, as the St. Louis scholars recognized that Pocock’s “country ideology” was Wood’s "republicanism" and they quickly picked up the term "republicanism” in their own works. $^{42}$

Fortunately, disagreements between historians of republicanism were not the weakness for that school of interpretation that it would have been for others. All of these historical interpretations had always recognized that republicanism was not a monolithic doctrine, but a political worldview that drew upon numerous strands of thought. The real disagreement for these historians (and the men they studied) was on which strands of thought had the most importance and how. The influence of the republican, ideological model(s) of the Revolution expanded throughout the 1970s, winning over first social and then numerous legal historians in the late 1970s and early 1980s. ${ }^{43}$

It was in the 1980s that the republican consensus gained an ascendancy

\footnotetext{
41 J.G.A. Pocock, Machiavellian Moment: Florentine Political Thought and the Atlantic Republican Tradition (Princeton: Princeton University Press, 1975), 423-505; Rodgers, “Career of a Concept,” 15-21.

${ }^{42}$ Rodgers, “Career of a Concept," 15-21.

${ }^{43}$ Ibid., 21-28.
} 
comparable to the one that the Beardians had enjoyed in the early twentieth century. The Beardian interpretation had been left shattered in the dust, and interpretations of the Revolution that tried to explain it in purely materialistic ways became eclipsed. The shift in historiography did not mean that economic or class related conflict became irrelevant to historians, because they did not. But economic causes and class tensions were more often placed within an ideological context, or at least the concurrent importance of ideology became almost universally recognized. Economic causes and conflicts became a current within the broader ideological views of what the Revolution was about. ${ }^{44}$

The republican consensus was not without its detractors, but even its most consistent antagonists like the historian Joyce Appleby did not proffer neo-Beardian or materialist alternatives, but rather has argued for ideological alternatives. More recently, in the mid-1990s, the legal historian John Phillip Reid argued that political historians within the republican consensus tradition had underplayed constitutionalism while emphasizing factional political thought. According to Reid, constitutional thought played a key role in the fissures that developed between Britain and British America in the 1760s and 70s, and ultimately led to the Revolution. Yet, even Reid professed no desire to supplant the republican consensus, rather he saw his work as a corrective to an oversight within the broader tradition, that had ignored legal thought as its own force. ${ }^{45}$

A pejorative term, "neo-Whig” had been sometimes used for these contemporary ideological interpretations, implying that they simplistically accepted the words of the

\footnotetext{
${ }^{44}$ Ibid., 28-29.

45 Joyce Appleby, "Republicanism in Old and New Contexts” in The William and Mary Quarterly Third Series, 43 (January, 1986): 20-34; Lance Banning, "Jeffersonian Ideology Revisited: Liberal and Classical Ideas in the New American Republic” The William and Mary Quarterly Third Series, 43 (January, 1986): 3-19; Issac Kramnick "Republican Revisionism Revisited” The American Historical Review 87 (June, 1982), 629-664; J.G.A. Pocock, "Between Gog and Magog: The Republican Thesis and the Ideologia
} 
Revolutionary generation as truth. Yet, as of 1987, the legal historian Stephen A. Conrad used the term neo-Whig in a purely descriptive sense, applying it to a general school of thought, with which he clearly identified. ${ }^{46}$ The neo-Whigs, if indeed that is what they were, had come far.

The general ascendancy of ideological interpretations of the Revolution, in the later half of the twentieth century, has had an effect on the popularity of Wilson among scholars. Indeed, the peaked interest in Wilson over the last forty years can be partially attributed to the neo-Whig atmosphere in history. ${ }^{47}$

For all of the political and institutional experimentation of the Revolutionary era, and the anticipated improvements in society that those changes would instigate, the Revolutionary generation never produced a Locke or a Machiavelli. No one but John Adams tried to produce a representative treatise of fundamental political theory for his

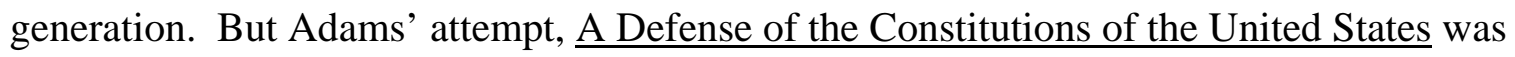
a failure among the generation that it proposed to represent. The treatise held old, even reactionary thinking by the time it was penned in 1787 , enough so that contemporaries gave $\underline{\text { A Defense a cold reception. }}{ }^{48}$ Thomas Jefferson used it to factional ends, blasting the treatise as the product of a monarchist mind. ${ }^{49}$

Other than Adams, James Wilson came the closest to penning a treatise for his generation. And Wilson's philosophy, though in some ways eccentric, was perhaps more

Americana” Journal of the History of Ideas 48 (April-June, 1987), 325-346; Reid, Constitutional History, Abridged Edition, ix-xvi.

${ }^{46}$ Stephen A. Conrad, “James Wilson’s ‘Assimilation of the Common-Law Mind'” Northwestern University Law Review, 84 (1989): 187-188.

${ }^{47}$ Ibid., 186-187.

${ }^{48}$ Wood, American Republic, 567-592.

49 Thomas Jefferson, “The Autobiography of Thomas Jefferson" in The Life and Selected Writings of Thomas Jefferson ed. Adrienne Koch \& William Peden (New York: Random House, Inc., 1972), 127. 
representative of his generation's thought following the establishment of the 1787 federal Constitution than was Adams'. Wilson, in his law lectures given at the University of Pennsylvania in 1790, brought together the various threads of radical American political thought, both "republican” and "liberal.” He forcefully rationalized these political views, interconnecting them with a philosophy about humanity and its society that was both metaphysical and practical. Historians can never know what would have been produced if he had not been interrupted by his mounting financial difficulties, but even in their unedited and half completed condition, Wilson`s law lectures are an impressive testimony to his conceptual abilities.

Another reason that Wilson's popularity has grown may be the fact that Wilson's highly democratic and progress-centered vision of the United States government coincidentally matched what the United States government has become in the twentieth and twenty-first centuries, better than the visions of any of the other Founders. Wilson envisioned a nationalistic and democratic federal government, replete with a powerful judiciary. ${ }^{50}$

Since the late sixties a flurry of articles on Wilson have been produced, and five monographs focusing on Wilson's thought have been published. Historian Mary T. Delahanty's monograph on Wilson was the first of these in 1969. In The Integralist Philosophy of James Wilson, Delahanty focused on Wilson's ability to unite apparently contradictory threads of thought, particularly “Aristotelian” civic humanism and Christian morality. Like Aristotle, Delahanty pointed out, Wilson emphasized the importance of civil society in achieving the good life and a secular moral code that

\footnotetext{
${ }^{50}$ Hall, Political and Legal Philosophy, 196-199; McCloskey, "Introduction” in Works, Vol. I, Wilson, 45-
} 48. 
perpetuated civil society. Wilson integrated these Aristotelian ideas with traditional Christian moral precepts. Delahanty marked the similarities in argument between Wilson and Aristotle on the one hand, and certain religious thinkers on the other. But, ultimately, Delahanty is not convincing, because the very premise of her work is plagued by oversimplification. Certainly parallels can be found between Wilson's thought and thinkers such as Aristotle or the early church fathers, but this parallel does not suggest an immediate, formative influence per se. What Delahanty's work really demonstrates is the dual influence of both Aristotle, Christian decretists and protestant writers on the whole canon of Western thought, a tradition of thought that Wilson drew from as a Westerner. In his law lectures Wilson occasionally quoted Aristotle and religious theorists but he used Enlightenment philosophes, English opposition writers and British jurists even more. Therefore, calling Wilson an “Aristotelian,” as Delahanty does, is deceptive. Nonetheless, the idea that Wilson is important as an integralist thinker has not gone away. ${ }^{51}$

Even before Delahanty, Robert Green McCloskey had noted Wilson's ability to "synthesize" various threads of thought. For McCloskey, the tenuous forces that Wilson integrated were concerns for property rights versus localism and a desire for a stable, commercial society versus populism in government. Ever since, the issue of Wilson's integration and synthesis of such "contradictory" thoughts has been an underlying theme of most histories on the Founder. Though that theme has been consistently more of the McCloskey mold than the Delahanty mold. ${ }^{52}$

\footnotetext{
${ }^{51}$ See Mary T. Delahanty, The Integralist Philosophy of James Wilson (New York: Pageant Press, Inc., 1969) and James Wilson "Lectures on Law" in Works, Vol. I and II Wilson, ed. McCloskey.

${ }^{52}$ Stephen A. Conrad, "Polite Foundation: Citizenship and Common Sense in James Wilson's Republican Theory” The Supreme Court Review (1985): 360-361; McCloskey, “Introduction” in Works, Wilson, 24-
} 
The legal historian Stephen A. Conrad latched onto Wilson’s tendency toward intellectual integration in his article "Polite Foundation: Citizenship and Common Sense in James Wilson's Republican Theory.” Conrad described a Wilson, conscientious of the conflict between liberal thought and republican thought, determined to find a unifying thread to bind the two contradictory philosophies together. Wilson found a solution, according to Conrad, in an optimistic vision of polite citizenship, by which, individuals would rationally consent to evident social need, and society would allow room for individual sensitivities and industry. ${ }^{53}$

The problem with Conrad's hypothesis is that no evidence exists for it in the primary sources. Wilson never acknowledged the existence of two monolithic political philosophies, pulling apart his generation. Wilson never worried in his writings over the contradictory attractions of "liberalism" and "republicanism” or "democracy" and "commercialism." 54 And, though a man very willing to brag on the apparent achievements of his generation, Wilson never noted a conciliation between any such "contradictory" political philosophies as being part of those achievements. The fact that Wilson did not see the contradictions between what contemporary historians might deem as "liberalism" and "republicanism" is highly suggestive. As the most concise and indepth political and legal philosopher of that generation, Wilson would have perceived the intellectual conflicts if anyone was to see them.

Historian Lance Banning, in answering the criticism of historians Isaac Kramnick and Joyce Appleby, has been compelled to blur the lines between "liberalism" and "republicanism" that republican historians of the Pocockian school have traditionally

25.

53 Conrad, “Polite Foundation,” 382-385. 
drawn so darkly. Banning admitted that,

Logically it may be inconsistent to be simultaneously liberal and classical. Historically, it was not. Eighteenth-century opposition thought was always a complex blend of liberal and classical ideas. So was the thought of America's Revolutionary generation. ${ }^{55}$

The overarching argument of Banning’s article is that the inherent differences between republican civic philosophy and liberal humanism were never realized by the Founders because their English intellectual heritage had been mercifully ambiguous.

A problem exists with Banning’s supposition when approaching Wilson, however. Wilson was far from ambiguous in his political philosophy, and drew definitive connections to "liberal" ideas such as the human compulsion, even right, to progress and the need for civic virtue among the nation's citizenry. Wilson's work suggests that Banning is not going far enough. In fact, "liberalism” and "republicanism” may not have even been logical contradictions, as the Founders utilized them. Though radical, the Revolutionary generation was not extremist -- except for their willingness to act militantly, when scruples necessitated such action. For example, no evidence exists that they ever envisioned the personal sacrifice involved in civic virtue to be all consuming within times of peace. Civic virtue was never trumpeted to extremes, any more than was profiteering individualism. Indeed, a contributive factor in the success of the American Revolution is that the Revolutionary generation understood practicality as a virtue and did not fall into the trap of dogmatic extremism that defined so many failed revolutions in history. These points move far beyond the goals of this essay but Wilson's intellectual discourses are suggestive on these points. Hopefully, that suggestiveness will be

\footnotetext{
${ }^{54}$ Conrad, “Polite Foundation,” 382-385; McCloskey, “Introduction” in Works, Wilson, 24-25.

55 Banning, "Jeffersonian Ideology Revisited,” 12. Also see Appleby, "Republicanism in Old and New Contexts,” 20-34; Kramnick, "Republican Revisionism Revisited,” 629-664; Pocock, "Between Gog and
} 
apparent in this essay.

The next Wilson monograph to be published, after Delahanty’s, was Geoffrey Seed's James Wilson. Seed concerned himself with Wilson’s political thought, focusing on its democratic nature and ideological consistency. The biography lacked depth on the whole, but gave a thorough analysis of Wilson's activity in the federal convention of 1787. ${ }^{56}$ Most important in Seed's work is his treatment of Wilson's support for common law. On the surface, Wilson's support for strong common law seemed to contradict his devotion to popular sovereignty and legal instrumentality. But as Seed demonstrated, on deeper analysis, the contradiction did not exist for Wilson. For Wilson the common law was simply the product of the popular sovereignty of past generations. Present generations continued to exercise their sovereignty over it through the rare exercise of legislation, but more importantly through sitting as jurors. In regard to the last point, Seed reminded the reader that in Wilson's time juries found for points of law as well as fact, and therefore had a potentially transformative power over points of law. And this legal process Wilson wholeheartedly supported as necessary in a free society. ${ }^{57}$

One of the better works on Wilson’s thought was Jean-Marc Pascal’s 1991 book, The Political Ideas of James Wilson, 1742-1798. Pascal placed Wilson within the republican tradition, connecting his thought with Enlightenment thinkers in continental Europe, as well as opposition Whigs in Britain. Another historian, George M. Dennison, had argued fourteen years earlier that Wilson propounded a "revolution principle." The revolution principle was grounded in an instrumental view of law, and ultimately

\footnotetext{
Magog,” 325-346.

56 See Geoffrey Seed, James Wilson (Millwood: KTO Press, 1978).

57 Conrad, “James Wilsons “Assimilation of the Common-Law Mind”,” 198-200; Seed, Wilson, 103-104, 151-153.
} 
constitutionalism. Government and law were simply instruments of the people that could be changed whenever the people felt it to be necessary. For Wilson, this principle had been properly embodied in the amendment process of the Constitution of 1787 -- a process that would allow for peaceful and popular "revolution" in the system. Pascal concurred with Dennison on this point, comparing Wilson's legal instrumentalism and popular sovereignty to Jean Jacques Rousseau's, and drawing a strong contrast between Wilson's constitutional philosophy and Lockean contractualism. ${ }^{58}$ Wilson’s ideas about popular sovereignty and constitutional instrumentality will play a crucial role in this essay, and will be discussed in greater detail in later chapters.

Historian Mark David Hall has brought together the various studies on Wilson’s thought while correcting what he thinks to be certain imbalanced views of Wilson's philosophy. Nothing particularly unique can be found in Hall’s Wilson monograph, so that the value of his work is as a historiographical synthesis and minor corrective. ${ }^{59}$ Perhaps most important was Hall's discussion of Wilson's federalism, which rescues Wilson's view from mere metaphor or the misguided interpretation that Wilson was promoting divided sovereignty. Wilson thought that sovereignty resided in a single source -- the people at large. When Wilson spoke of the people distributing power as they wished between the federal and state governments he was not speaking of sovereign power, but day to day instrumental powers. ${ }^{60}$ Though Hall agreed with the legal historian Stephen A. Conrad that Wilson hoped the federal nature of American government would help to cultivate good citizens, Hall would not relegate Wilson's “federalism” to a metaphorical status, symbolizing the general concept of constitutional republicanism.

\footnotetext{
58 Dennison, “The “Revolution Principle”," 172-176; Pascal, Political Ideas, 28-47.

59 Hall, Political and Legal Philosophy.
} 
Hall recognized the more practical role of the states in Wilson's thinking, as additional countervalence in government (versus the federal government) to guard against official corruption. ${ }^{61}$

The latest monograph to be published on James Wilson focuses on four of the Founders, including Wilson. James H. Read's Power vs. Liberty: Madison, Hamilton, Wilson and Jefferson compares the thought of these men concerning the relationship of liberty to political power. Jefferson provides the ideological backdrop to the others because, according to Read, Jefferson, unlike the other men, continued to see political power as an inherent bane to liberty. Hamilton is Jefferson's polar opposite, who assumed that the entire idea of power contradicting liberty was either archaic or universally incorrect. Madison and Wilson hold the middle ground in Read's interpretation. These two acknowledged that power could destroy liberty, but that power was also necessary to sustain it. ${ }^{62}$ Necessarily, Read discusses topics related to power and liberty, including sovereignty and rights. The work does not disclose anything new about Wilson, but it is valuable as a comparative study.

In the present thesis the view of Wilson as consistently democratic and nationalistic, as provided in the previous described works, will be embraced. As Pascal and Dennison assert, Wilson did not think of the Constitution of 1787 as a contract, and Wilson's instrumental approach to the Constitution was heavily influenced by his concurrent dedication to contemporary popular sovereignty. These arguments bear

\footnotetext{
${ }^{60}$ Hall, Political and Legal Philosophy, 160-173.

${ }^{61}$ Stephen A. Conrad, “Metaphor and Imagination in James Wilson’s Theory of Federal Union” Law and Social Inquiry: Journal of the American Bar Association, 13 (1988): 1-70; Hall, Political and Legal Philosophy, 154-160; Ralph Rossum, “James Wilson and the 'Pyramid of Government”' The Political Science Reviewer, 6 (1976): 140-141; Seed, Wilson, 76-77.

62 James H. Read, Power vs. Liberty: Madison, Hamilton, Wilson and Jefferson (Charlottsville: University
} 
restatement and have an important place in the overall thesis of this essay. However, an additional intellectual element existed, directing Wilson’s instrumental approach to constitutional government. The purpose of government and law, according to Wilson, was not only to protect the good order of society, but was to facilitate its civil progress. Contractualism of any sort would have been too rigid to sustain such a progressive vision.

In a contract, the people would only have a right to actively change government if the government committed a breach of contract. For Wilson, not only was it unacceptable to think that sovereignty had been transferred to the government under contract, it was also unacceptable that instrumental powers be conferred contractually. The people had to be empowered to change their government whenever they found it advantageous for their progress.

For the purposes of the present argument the terms progressivism or progressive is meant to indicate a general philosophical sensibility contradistinguished by conservatism. The word "progressive” specifically has been chosen because it generally implies a willingness to affect rapid change and because it was Wilson's word of choice in presenting his own philosophical position. (Progressive will not mean anything necessarily reflecting the very particularistic political platforms of the early twentiethcentury Progressive movements.)

Conservatism is an ancient world-view demanding that slow or non-extant change is always preferable to rapid change -- rapidity always doing more harm than good. So governmental activity to affect rapid change should be avoided and revolutionary changes in private society should be resisted. The progressive sensibility, on the other hand, considers rapid change as capable of being overall productive, and even preferable 
in many instances. Government, or other forces in society, may legitimately and hopefully exert positive force to begin or exacerbate proper advances in society with all due haste. It will be shown that Wilson's thought was, at center, progressive. In Wilson's usage "progress” referred to a pro-active advancement of either a material, sociopolitical or moral nature. But Wilson's thought interwove these categories of progress -- understanding them to exist in a symbiosis. And the nexus of every truly progressive movement was to be found in the will of the People at large; advancement was derived from the liberal activities of the People and their instruments.

Two general formats were available to choose from for discussing Wilson's life and thought. The first, and perhaps most popular in intellectual biographies, was used by Seed and Hall in their monographs on Wilson. The first sections of the monographs were general biographies of Wilson and his career. Each chapter afterward involved some aspect of Wilson's philosophy. Both Seed and Hall used this style very effectively, but it is not without its dangers. The thought of the subject might be represented, incorrectly, as independent of the larger historical changes surrounding him. And, connected to this, the subject's philosophy might appear unchanging, which is rarely the case. For example, when reading either Seed's or Hall's work, the reader gets the impression that Wilson's thought concerning popular sovereignty was unchanging, but that was not the case. Though it is not the central goal of this work, it will be shown that Wilson initially embraced a contractual theory of government, at least loosely. It was sometime between the controversy over independence and the federal convention of 1787 that Wilson rejected contractualism, adopting an instrumental view of constitutionalism.

The second possible format is well represented in historian Eric Foner's 
intellectual biography of Thomas Paine. ${ }^{63}$ This style describes the thinking of the subject while chronologically describing the events in their lives. It is a style that can best reflect the changes in a subject's thinking, and emphasize what led them to their new conclusions. It is this later stylistic format that will be employed to tell James Wilson's story and describe his thought. At times it may seem as if Wilson's story has given way to the larger stories of the Revolution in Pennsylvania or general American constitutional development. At others, the story will appear repetitive. If so, it is only because Wilson's thinking cannot be truly appreciated if separated from its historical context. At times it will be expedient to dwell on certain tangential issues, the relevance of which will become apparent later in the text.

The next chapter of this essay examines Wilson's first years in America. After a brief discussion of Wilson's life in Scotland and immigration to British America in 1765, the narrative progresses up to 1777 when Wilson's first Congressional career came to an abrupt end due to factional travails. It was in this time frame that Wilson adopted radical Whig principles. Chapter 2 also demonstrates Wilson's early acceptance of contractual principles of government, at least in relationship to the British monarch. Though the precise experiences that convinced him to embrace instrumentality in the law cannot be known, some informed speculation will be proffered.

In Chapter 3 Wilson's continued dedication to American revolutionary principles is demonstrated, while explaining the reasons for popular suspicion against him. At first being misunderstood as an aristocrat, Wilson was able to re-obtain a seat in Congress. And by 1786 Wilson's second Congressional career became secure from the factional strife between Constitutionalists and Republicans in Pennsylvania.

${ }^{63}$ Eric Foner, Tom Paine and Revolutionary America (New York: Oxford University Press, 1977). 
Building worries over the health of the American states under the Articles of Confederation is central in Chapter 4. Wilson proved to be a continental nationalist supportive of stronger central government. Yet, unlike many others who came to support stronger central government by 1787 , Wilson was not goaded by a fear of socio-political dissolution in the United States. Wilson saw the United States as a single political society long before the constitutional convention of 1787 . As a result, Wilson did not value the new constitution as a conservative instrument, but an instrument reflecting progressive realities.

Chapters 5 and 6 examines Wilson's career as a constitution maker and his understanding of popular sovereignty and legal instrumentalism within the context of those constitutions. His dedication to popular sovereignty and centralized government dictated that he champion continental and democratic institutions. The depth of Wilson's sincerity becomes apparent in Chapter 5 when looking at his activities in the federal convention of 1787 . This work will not attempt to re-interpret the whole of the constitutional convention, that would be a goal too great for this essay. For a more general and in-depth interpretation of the constitutional convention, this author suggests the work of historian Jack N. Rackove. ${ }^{64}$ However, the activity of Wilson in the convention will be extensively explored. James Madison's Notes On The Debates Of The Federal Convention is the key primary source for Wilson's activity, and indeed, on the activity of the federal convention in general.

Wilson's continued dedication to popular government is demonstrated in Chapter 6. His partisanship during the ratification controversy, and his leadership in framing the

\footnotetext{
${ }^{64}$ See Jack N. Rackove, Original Meanings: Politics and Ideas in the Making of the Constitution (New York: Alfred A. Knopf, 1996).
} 
Pennsylvania state constitution of 1790 will be the focus.

Chapter 7 focuses on Wilson's progressivism and his law lectures given at the University of Pennsylvania toward the end of his career. In his lectures Wilson brought rhetorical clarity to his philosophy and vision for an American future. Wilson makes clear the constitutional connection between popular sovereignty and civil progress, and how they were to be understood within the American system that he helped mold.

Chapter 8 concludes with a restatement of the thesis. And the present author's precise understanding of Wilson's importance will be clarified.

\section{CHAPTER II}

\section{FROM OPPOSITION WHIG TO REVOLUTIONARY}

Wilson's dedication to the American colonial cause stretched back to at least the 1765 Stamp Act controversy. Always a staunch Whig, Wilson would, over time, prove to be one of the most convinced populists and nationalists of the revolutionary generation. In the first years of Wilson's life in America, the Scottish immigrant achieved prominence as a lawyer and dedicated Whig, was branded an aristocrat by his enemies, and became an experienced and well-liked member of Congress. ${ }^{65}$

\footnotetext{
65 "Populist" for the purpose of this work, means someone who supports comparatively broad community participation in government. Populist is distinct from "democrat" which implies support for majority rule.
} 
Born in Fife, Scotland, in 1742, James Wilson was the son of conservative Presbyterians. William and Alison Lansdale Wilson, his father and mother, were dedicated to retaining the old strict covenant in the face of a rising trend of liberalism and centralization in the Scottish Church. James Wilson had been marked by his parents for an ecclesiastical career from an early age. His family sent him and his three younger brothers to a grammar school near their home in Caskardy, and it was there that Wilson was first introduced to Latin writers such as Cicero and Sallust. At the age of fourteen Wilson won a bursar's scholarship from the University of St. Andrews only a few miles from Caskardy, and matriculated to the University in 1757 to study for the ministry. ${ }^{66}$ In the College of Saint Salvator at St Andrews the young and impressionable Wilson submersed by his teachers in the philosophy of the Enlightenment. Historian Charles Page Smith argued in his biography of James Wilson, Wilson's thinking was lured away from the strict Calvinism of his parents to the "softer...doctrines of the Enlightenment.” James Hutchison, Thomas Reid, Hugo Grotius, David Hume, and other Enlightenment thinkers were doubtlessly made available to Wilson in his philosophy classes. These theorists would later prove prominent in Wilson's thinking. ${ }^{67}$ Wilson’s academic career at St Andrews abruptly ended, however, when his father died. Being the eldest son in a family that had no other males in their majority, his father's death forced Wilson to attend to the economic well being of his mother, brothers and sisters. He left school to support his family and he secured a job tutoring young

\footnotetext{
While a democrat is certainly a populist, a populist is not necessarily a democrat -- broader community participation need not necessarily mean bare majority rule. Wilson certainly makes comments that are suggestive of democratic sentiments, but not until his participation at the constitutional convention. Before the Convention, however, Wilson did make statements supporting broader representation for the community.

${ }^{66}$ Smith, Wilson, 8-15.
} 
boys. During his short career as a tutor Wilson made up his mind that he would never become a minister. In addition, he found teaching relatively unrewarding. He wanted more than the life of a countryside grammarian. Wilson was finally freed from the bondage of low-paying pedagogy in 1765 when one of his sisters married and some of his brothers having become older, became economically viable and supported their mother without James' help. He traveled to Edinburgh to study bookkeeping and accounting. ${ }^{68}$ Though he found Edinburgh sufferable, Wilson's attention was gradually turning to British America. Before Wilson had come to Edinburgh his cousin and friend Robert Annan had achieved the Presbyterian ministry and relocated to southern Pennsylvania. Other relatives had made their way across the Atlantic as well and sent back positive descriptions of their new homes. Finally, becoming determined to make the crossing himself, he had only to overcome the protestations of his mother and obtain the money to make the crossing. Once he convinced his mother, Wilson's relatives in Fife raised money for his voyage. ${ }^{69}$

Arriving in New York in the fall of 1765, Wilson continued on to Philadelphia. Bearing a letter of introduction to Reverend William Smith, the trustee of the College of Philadelphia, Wilson secured a position as a Latin tutor. The College proved kind to James Wilson and he must have impressed the faculty. Just one year later, in 1766, he received an honorary masters degree from the College along side Joseph Reed. ${ }^{70}$

Yet, Wilson was again feeling restless. In the land of lawyers that was colonial America it became evident to Wilson that the most prominent men in Pennsylvania were

${ }^{67}$ Smith, Wilson, 17.

68 Ibid., 17-18.

69 Ibid., 19-20.

70 Ibid., 23. 
lawyers. The respect, wealth and power that many lawyers held must have been attractive to Wilson, who was beyond doubt an ambitious young man. So, later in the same year that he received his master's degree from the College of Philadelphia, Wilson left the College and apprenticed himself under John Dickinson to study law.

In order to pay Dickinson's fee, Wilson bought a small farm on credit from his cousin Robert Annan. Wilson then sold the farm to Dickinson for money to pay Dickinson's fee and have money to live on throughout the apprenticeship. ${ }^{71}$ It is ironic that this introduction to land speculation as a source of wealth allowed Wilson to enter the world of law. Just as most of Wilson's later accomplishments involved law and the philosophy of law, he was financially troubled and then ruined in later life by incredibly reckless land speculations. That financial failure stagnated his judicial career, tarnished his reputation and eclipsed his significance. ${ }^{72}$

Wilson's study of the law under Dickinson ranged from procedural matters of contract and torts to the 1701 constitution of colonial Pennsylvania and the history of the colony's governors. Wilson was also immersed deeply into legal theory. Looking for evidence of what Wilson studied in his meticulous study notes, Wilson's biographer Charles Page Smith found a broad treatment of legal theory. Hume, Montesquieu, Ferguson, Blackstone, Hooker, Bacon, Bolingbroke, Locke and Sidney all share influence on Wilson's notes according to Smith. Wilson also wrote down general categories of law. Probably suggested to him by Dickinson, these categories of law were Natural, Revealed, “General Customs, Maxims, Particular Customs, (and) Statutes.”73 Twenty-four years later Wilson would again put great importance in such a categorization

\footnotetext{
71 Ibid., 24.

72 Hall, Political and Legal Philosophy, 31-34.
} 
of the law in structuring his law lectures at the College of Philadelphia. The particular categories had, however, changed. By 1790, Wilson had decided to organize law in a way closer to Richard Hooker's: law eternal, law celestial, laws of matter, laws of natural man and oracular law. ${ }^{74}$

Dickinson's influence aside, the colonial world in which Wilson lived was transforming his thinking. When he landed in New York angry mutterings continued to abound over the Sugar Act of the previous year. And opposition politics reached a fevered pitch throughout the colonies over news of the Stamp Act by the time Wilson received his M.A. from the College of Philadelphia. ${ }^{75}$ Though Pennsylvania’s conservative, Quaker dominated Assembly failed to send delegates to the Stamp Act Congress, radical politics was alive and well in Philadelphia. Joseph Galloway’s conservatives had won the day in the Assembly by only one vote, but through the use of committees, Philadelphians organized to resist Parliament. They convinced the city’s appointed stamp agent, John Hughs, not to exercise his duties and the city’s merchants formed a boycott against imported British goods. ${ }^{76}$

Wilson’s newfound mentor, John Dickinson, was drawn into Philadelphia’s radical committee politics by the mid-1760s. ${ }^{77}$ It was shortly after Wilson finished his tutelage that Dickinson penned his famous “Farmer's Letters” to defend the cause of Whig resistance in colonial America. The public success of the "Farmer's Letters" in 1767 inspired Wilson to pen his own opposition piece, Considerations on the Nature and

73 Smith, Wilson, 24-26.

74 Pascal, Political Ideas, 76-80.

75 Smith, Wilson, 26.

76 Richard Alan Ryerson, The Revolution is Now Begun: The Radical Committees of Philadelphia, 17651776 (Philadelphia: University of Pennsylvania Press, 1978), 26-33.

77 Ibid., 26-33. 
Extent of the Legislative Authority of the British Parliament, later in the same year. Yet, Considerations on...Parliament would not be published until $1774{ }^{78}$

Wilson had finished his apprenticeship under Dickinson by February of 1767, approximately half a year after he had begun. Soon after, Wilson was practicing in the Court of Common Pleas in Philadelphia and was, by summer, working his way out into the western circuit. Shortly after Wilson moved his practice to Reading, on the borders of the Pennsylvanian frontier, he submitted his Considerations on...Parliament to Dr. Francis Alison for an opinion. Alison was an older professor of Metaphysics and Logic and vice-provost of the College of Philadelphia. Billy White, through whom Wilson sent his work, criticized Wilson that it should have gone instead to Dr. John Ewing, professor of Natural Law. The reason why Wilson did not prefer to send Considerations on...Parliament to Ewing is unknown. ${ }^{79}$ He may have developed a closer relationship to Alison while at the College. And Wilson was probably sure of his work's natural law foundations, but was still concerned whether or not he had reasoned well from those foundations.

Wilson's choice in the matter may seem of small consequence but it is in fact very telling of the young Wilson's thinking on epistemology and law. An older Wilson, delivering law lectures at the College of Philadelphia, elucidated on these issues, demonstrating a deep grounding in Scottish common sense thought. He asserted that Thomas Hutchinson had been right when he said that morality was the perception of God's law or natural law (Wilson never made a distinction between the two.) In addition, Wilson thought that all human beings had this moral perception. But what could actually

\footnotetext{
78 Hall, Political and Legal Philosophy, 12.

79 Smith, Wilson, 36.
} 
be perceived were fundamental moral precepts (an example for an older Wilson would probably be sovereignty.) But taking those fundamental precepts and applying them to specific situations in the ever-changing world required reasoning. And, unlike moral perception, reasoning was not an equally distributed faculty. Though reason was necessary for human beings to apply their moral understanding to the day to day world, poor or corrupted reasoning was the root of corruption and evil in the everyday world. Poor reasoning could corrupt the application of morality or even cloud moral perception itself. Indeed, later on, corruption would be how Wilson explained not only evil in the world but immorality among the uncivilized -- their power to reason had not been cultivated and refined. ${ }^{80}$

Though Wilson did not write on epistemological issues until he was an older man, he had probably come early to his concept of moral perception, reason, and their relationship to law. He had been exposed to these concepts originally as a boy at St. Andrews. And his immersion in law under Dickinson probably inspired Wilson to an early effort to fit together Scottish common sense thought and law as it existed in the trans-Atlantic British world. In looking for criticism, it was consistent for Wilson to seek out advice on his reasoning, but not the fundamental precepts upon which he based his argument. To believe Wilson's own claims in the Advertisement at the front of Considerations on...Parliament when he finally published the pamphlet, the conclusions he reached had surprised even him. ${ }^{81}$

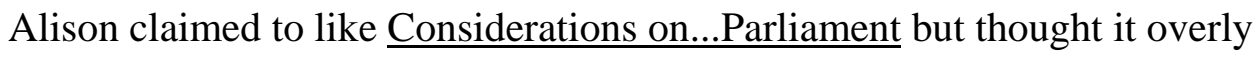

\footnotetext{
80 James Wilson, “Lectures on Law” in Works, Vol. I, ed. McCloskey, 132-146; Hall, Political and Legal Philosophy, 74-78.

81 James Wilson, "Considerations on the Nature and Extent of the Legislative Authority of the British Parliament” in Works, Vol. 2, ed. McCloskey, 721.
} 
radical. ${ }^{82}$ He warned Wilson against publishing it because conservatives still controlled politics in Philadelphia. The response to Dickinson’s “Letters” had by no means been entirely positive in the city. ${ }^{83}$ When the non-importation agreement between Philadelphia merchants fell apart from factional in-fighting, Wilson conceded to Alison's opinion. Wilson would later cite the failure of the non-importation agreement as the central reason for not publishing in $1767 .^{84}$

When Considerations on...Parliament was published, many in the radical movement were already coming to the same conclusions that Wilson had in his pamphlet. By 1774, it held no surprises. ${ }^{85}$ But within the context of 1767, Wilson’s reasoning had been far ahead of its time.

Dickinson, in his "Letters" had argued that Parliament could legislate for British America in cases of external regulation in the interest of promoting the wealth of the whole empire. They could not regulate the internal affairs of the colonies and especially could not do so to raise revenue. Otherwise, the colonists would be denied their core English right to be taxed only by their own representatives. Wilson's argument was not dissimilar but went much further than Dickinson's and denied Parliament the right to regulate for the colonies in any case whatsoever. ${ }^{86}$

First, Wilson moved through examples of how Parliament could be as corrupt and threatening to liberty as the King. According to Wilson, Parliaments could be kept virtuous only through frequent elections, among other checks on power. The British

82 Hall, Political and Legal Philosophy, 12.

83 Smith, Wilson, 36-37.

${ }^{84}$ Wilson, "Considerations on...Parliament” in Works, Vol. 2, ed. McCloskey, 721.

85 Smith, Wilson, 36.

86 Don Cook, The Long Fuse: How England Lost the Colonies, 1760-1785 (New York: The Atlantic Monthly Press, 1995), 125-126; Hall, Political and Legal Philosophy, 12-13. 
constitution guaranteed the election of parliamentary representatives by free, propertied Britons. Parliament had an authority to legislate because "the commons" had given their consent to it in the understanding that their liberties would be protected. That trust could be extended because Parliament's "interests, and that of their families, friends, and posterity, cannot be different from the interests of the rest of the nation.” Popular representation in the legislative process was not only a right of all propertied British subjects but a constitutional check on the power of Parliament. Legislative power could not be constitutional if it was not established and maintained by consent. Wilson ignored the idea of parliamentary sovereignty and assumed that parliamentary power was purely delegatory. He did not yet use the words "sovereignty of the people" or "popular sovereignty,” but Wilson was implicitly arguing that the supreme power had been derived from the people, and had been vested in the British constitution, not British Parliament. ${ }^{87}$

Using these principles, firmly rooted in British constitutional thought as colonists understood it, Wilson cited cases in law that supported British America's Whig opposition. Central in Wilson's examples was Lord Coke's judgment that the Irish could not be taxed because they had no representatives in Parliament. Wilson concluded that "The American colonies are not bound by the acts of the British Parliament, because they are not represented in it.” Wilson made no distinctions between internal and external regulations. ${ }^{88}$

Yet like most British Americans -- even British American radicals until 1775 -Wilson was still willing to pay deference to the authority of the monarchy, and the idea that contractual obligations between the King and his subjects existed. The obligation of

87 Wilson, “Considerations on...Parliament” in Works, Vol. 2, ed. McCloskey, 724-731.

88 Ibid., 732-738. 
dependence that the colonies owed to Great Britain only existed through the person of the King. Citing Francis Bacon for legal support, Wilson argued that "the only dependency which they (the colonists)...ought to acknowledge, is a dependency on the crown.” It was the only dependency that had precedence and "the colonists ought to be dependent on the king, because they enjoy...his protection.” The allegiance of subject to monarch existed within a reciprocal relationship. In return for protection, subjects owed their king obedience and the protection of the king was a birthright. “An Englishman, who removes to foreign countries” Wilson continued, "owes the same allegiance to his king...(and is)...still entitled to the advantages promised by law (and) to the duties of it.” Wilson even sounded what appears to be an ultra-conservative note concerning monarchy. Because the King protects subjects even when they are children, before their allegiance can be meaningful, every subject had a debt of allegiance to the king for services already rendered. $^{89}$

Nonetheless, the power of the monarchy was also limited by the British constitution -- the embodiment of the contract between the King and his subjects. The British monarchy did not exist to protect life alone, but also existed to protect liberty. The constitution dictated that not even the king could compel the colonies to unconstitutional actions like obeying Parliament. As Wilson pointed out in the middle of his discussion on Parliament's authority “the Americans are bound neither by the assent of the king, nor by the votes of the lords, to obey acts of British Parliament."90 In his last paragraphs Wilson described a federal idea of empire predating John

89 Ibid., 742-745.

90 Ibid., 732. 
Adam's argument for the same thing six years later. ${ }^{91}$ Describing the appropriate imperial powers of the king, Wilson wrote "he has a negative on the different legislatures throughout his dominions, so that he can prevent any repugnancy in their different laws.” The British King’s purpose was to ensure imperial comity and equity, while British Parliament is denied special status in this statement. Britain's Parliament was merely one of a multitude of legislatures in the King’s dominions. Under the British constitution, King and Commons were to act as countervailing powers that "checked the progress of arbitrary power” and the colonies had their own Commons in the form of their local assemblies. These local assemblies had the sole right to legislate for their respective colonies and should exist in a constitutional balance with the monarchy, like British Parliament in Great Britain. ${ }^{92}$ Historian Mark David Hall has written that Wilson “developed the concept that would be later known as the...'commonwealth’ status of English colonies." "Developed” is probably too strong of a word. Wilson was proposing a hazy vision deeply rooted in a well-remembered pre-existing tradition of imperial/colonial interaction. Wilson, and later Adams and Jefferson, described the actual nature of the empire before war debt made Parliament more jealous of its own imperial influence; the empire had been better for British Americans before the Seven Years War. ${ }^{93}$ But they were also arguing for something new because their immediate peril forced them to envision a new, positive codification of that older arrangement that would extend even into "external” regulation. British Americans wanted an arrangement that would guarantee British American liberty from the avaricious powers that appeared to be growing in Britain itself.

91 Hall, Political and Legal Philosophy, 13.

92 Wilson, “Considerations on...Parliament” in Works, Vol. 2, ed. McCloskey, 744-746. 
Considerations on...Parliament is interesting for a number of reasons. It suggests the speed with which Wilson embraced radical thinking in British America as well as his ability to think ahead, particularly on key theoretical issues. A blend of general influences can also be seen in this work from Enlightenment thought to the concerns of the Commonwealth writers with corruption. A strict adherence to what legal historian John Philip Reid has called the common law constitutional tradition, can also be seen. Wilson's pamphlet places great emphasis on legal precedence as would be expected in a common law argument. Most important, these passages evidence Wilson‘s continued dedication to the monarchy, as well as his implicitly contractual conceptualization of government and popular rights. ${ }^{94}$

After deciding not to publish his first opposition pamphlet, Wilson turned to his business in Reading, Pennsylvania. Reading was a western town with an economy based in farming and the processing of beaver pelts. ${ }^{95}$ Moving into western Pennsylvania, Wilson hoped to make his legal practice more profitable by taking advantage of land controversies between litigious settlers. But this idea was the hope of many lawyers. Wilson found the western settlements well populated by fellow professionals. Nonetheless, Wilson proved a highly proficient practitioner and his business profited. He intermittently rode the western circuit while maintaining his Philadelphia contacts. In 1769, he began arguing cases in the Pennsylvania Supreme Court at Philadelphia. By 1770, when he moved to the Cumberland Count seat at Carlisle, Wilson's legal career was in rapid ascension. In 1771 he married his first wife, the prominent Rachael Bird of

93 Hall, Political and Legal Philosophy, 13.

94 John Phillip Reid, Constitutionalism in the Age of the American Revolution, Volume 3: Authority to Legislate (Madison: The University of Wisconsin Press, 1986), 77-86, 151-158.

95 Smith, Wilson, 29. 
Berks County, bringing with her the wealth of an heiress. And by 1772, James's and Rachael's first child, Polly, was born. ${ }^{96}$

The British American colonies also reached a new bar in 1772. Parliament had retained the tea tax from the failed Townshend Duties in 1770 . Yet, as was always the case with Britain's attempt to establish duties over the colonies, the tea duty proved difficult to enforce. Parliament was, nonetheless, determined to see the tax enforced and in 1772 tried to empower its colonial officials to enforce it. British Americans reacted. The British vessel, Gaspee ran aground chasing a ship in Rhode Island and was burned by a crowd. And Sam Adams went to work forming Committees of Correspondence to promote uniform resistance throughout the colonies. $^{97}$

Philadelphia’s opposition leaders, reacting to Sam Adam's call, set up their own Committee of Correspondence and reinvigorated their resistance movement. Under the shadow of Parliament's Coercive Acts against Massachusetts in 1774, the Philadelphia Committee effectively usurped much of the political influence of the intransigently conservative Governor and colonial Assembly. The various counties of Pennsylvania formed committees as well, connecting outlying towns to the committee movement in Philadelphia. $^{98}$

Many prominent citizens in Carlisle involved themselves in the standing Cumberland Committee of Correspondence. Wilson was one of the movement's formative leaders. He helped draw up the resolutions creating the Cumberland Committee. Echoing the Committee in Philadelphia, these resolutions condemned the

\footnotetext{
96 Ibid., 30-49.

97 Edmund Cody Burnett, The Continental Congress (New York: The MacMillan Company, 1941), 11-21; Cook, The Long Fuse, 149-166.

98 Ryerson, The Revolution is Now Begun, 63-64.
} 
Coercive Acts and called for a Continental Congress. Within days after its formation, the Cumberland Committee sent out a group of delegates, that included Wilson, to convene with others at a Provincial Convention in Philadelphia, and discuss the upcoming Continental Congress. ${ }^{99}$

Events moved quickly in Philadelphia and in British North America in general. The Provincial Convention in Philadelphia drafted instructions to the Pennsylvania Assembly. Primarily the work of John Dickinson, and edited by a special committee that included Wilson and Joseph Reed, the instructions demanded the appointment of delegates to the Continental Congress. The Assembly, feeling intense political pressure, acquiesced to the Convention's demands. ${ }^{100}$ But to mitigate the effect of the first Continental Congress, conservatives in the Assembly appointed a heavily conservative delegation that included Joseph Galloway himself. Only one member of the delegation, Thomas Mifflin, was known to be sympathetic to the radical committee movement. ${ }^{101}$

Fortunately for the Pennsylvania Whig opposition, Galloway and his allies did not undermine the pro-active nature of the Congress. Though conservatives dominated the Pennsylvania delegation, Mifflin and Dickinson were better connected politically with the delegates of the other colonies than Galloway and his followers. The radical committeemen had been communicating for years with opposition leaders in the other colonies while inward looking conservatives, like Galloway, ignored external relations. Galloway also miscalculated the popularity of the opposition movement in the other colonies. He assumed (wrongly it turned out) that the delegations from the other colonies would be predominantly conservative like his own. The fact that they would convene in

\footnotetext{
99 Smith, Wilson, 51-61.

100 Ibid., 51-61.
} 
Philadelphia also probably gave Galloway a false sense of security. The cold truth of Galloway's political impotence probably began to occur to him when the Congress chose to convene in Carpenter's Hall, the headquarters of radical committee activity in Philadelphia since its inception. ${ }^{102}$

Emboldened by the Suffolk Resolves, the Continental Congress recommended a non-importation agreement among the colonies and Committees of Association to enforce it. ${ }^{103}$ Radical committeemen called another Provincial Convention in Philadelphia to support and act upon the recommendations of Congress in January 1775. The second Provincial Convention also suggested that programs be established to promote domestic production. ${ }^{104}$ Wilson again played a key role, this time by delivering the Convention's only formal oration. Shortly after the first Provincial Convention, Wilson had finally published his Considerations On...Parliament. Perhaps the timely pamphlet, exceedingly well argued though no longer ahead of its time, was enough to win him the honor of delivering the singular oration. And Wilson's dedication to the committee movement would have also been apparent, by this time, to the rest of the radical leadership. In his speech, Wilson outlined the complaints of British America against a tyrannical British Parliament, described the events that necessitated the acceleration of American resistance, and lamented the lack of understanding that the British people themselves had shown. He re-argued his main theme in Considerations...On Parliament, but more boldly implicated that the king may be at fault

\footnotetext{
101 Ryerson, The Revolution is Now Begun, 62.

102 Ibid., 90-91.

103 Burnett, Continental Congress, 42-47.

104 Ryerson, The Revolution is Now Begun, 101-102.
} 
and referred to the colonial assemblies as parliaments. ${ }^{105}$

In the summer of 1774 , as the Continental Congress was still meeting, radicals won an electoral victory in Pennsylvania. They took many seats in the colonial Assembly, Dickinson himself winning a seat. ${ }^{106}$ By mid-1775, in the wake of the bloodshed at Concord and Lexington the colonial assemblies agreed to convene another Continental Congress. Again, the Pennsylvania Assembly sent delegates to Congress, but this time the delegation would be dominated by dedicated opposition Whigs. The Assembly appointed Benjamin Franklin, James Wilson, and Thomas Willing to the loss of the Galloway conservatives. ${ }^{107}$ With this appointment, Wilson took his first step into continental politics.

In Congress, Wilson busied himself with committee work. Congress first appointed Wilson to a committee for considering a letter from Massachusetts's Provincial Congress at Watertown. The letter asked two questions: should the Provincial Congress take over governing Massachusetts? And, would the Continental Congress send someone to take over the army surrounding Boston? On the later question Congress answered in the affirmative, eventually selecting a Virginian with extensive military experience, George Washington. ${ }^{108}$ On the first question, however, the congressional committee’s answer was nebulous. It advised that the Assembly take on whatever responsibilities they thought necessary to save their country and maintain the union of the colonies. ${ }^{109}$ Yet, Congress placed an interesting caveat on its advice. The Massachusetts Provincial

\footnotetext{
105 James Wilson, “Speech Delivered in the Convention for the Province of Pennsylvania” in Works, Vol. 2, ed. McCloskey, 747-758; Smith, Wilson, 51-61.

106 Ryerson, The Revolution is Now Begun, 91-93.

107 Ibid., 62-63.

108 Burnett, Continental Congress, 62, 71-72; Smith, Wilson, 65-66.

109 Burnett, $\underline{\text { Continental Congress, }} 71$.
} 
Congress was to act defensively only until “a Governor of His Majesty’s appointment, will consent to govern the colony according to its charter.” The mentality of the congressional majority rings out in this statement. As late as the Spring of 1775, the colonies were still uniting, and fighting to get back into the British Empire on more equitable terms, not out of the British Empire -- yet. They continued to hope that King George III would come to their rescue.

The King could not and did not want to help the cause of local representation in British America. Though British Americans did not acknowledge it, Parliament was sovereign in Britain, not the King or the mixed constitution. ${ }^{110}$ Paradoxically, though George III certainly wanted to control Parliament he had no aspirations of becoming a supreme monarch. The King disliked the American idea of multiple assemblies under the Crown because it would have strained his ministry's finances. Sustaining the necessary systems of patronage to keep them all in line would have been too difficult and expensive. It was simply easier to focus on a single Parliament than many. ${ }^{111}$

But few colonists understood this new British reality. Even if they had, it would have offended them. So, when George III ignored the Olive Branch Petition it irritated the colonists. And when he declared the colonies to be in rebellion, most in the colonies were dumbfounded. The one constitutional connection that British Americans believed existed between themselves and Great Britain was the monarchy. ${ }^{112}$ After the King condemned them, their own constitutional arguments left them with only two options: either capitulate or declare war on the monarch. In doing the latter, geography made it

\footnotetext{
110 Reid, Age of the American Revolution, Vol. 2: Authority to Tax, 63-68; J.G.A. Pocock, "1776: The Revolution Against Parliament” in Three British Revolutions, 1641, 1688 and 1776, ed. J.G.A. Pocock, (Princeton: Princeton University Press, 1980), 280-281.

111 Pocock, “Against Parliament” in British Revolutions, ed. Pocock, 280.
} 
impossible to overthrow the British monarch and replace him with another. Therefore, making war against the king would have to mean separation -- independence. ${ }^{113}$ The fact that they eventually chose the latter says a lot about them, but so does their reticence in accepting that ultimate solution.

Shortly after the King's rejection of the American cause and his concurrent accusation that their goal was independence, Continental forces met disaster in Canada. Canadians repelled the American attempt to liberate Quebec, resulting in the maiming of one of America's finest military leaders, Benedict Arnold. It was in this disheartening atmosphere that James Wilson moved to make a declaration in response to the king's charges. In his motion Wilson acted as if Congress should prepare a rebuttal to the king's claim that they wanted independence. This alarmed John Adams whose thinking was ahead of most of his associates. Adams had already come to the conclusion that independence was not only plausible but preferable. He had already proposed a committee to draft articles of confederation but conservatives, marshaled by John Dickinson, had blocked the move. Adams in turn tried, but failed to block the drafting committee for the proposed rebuttal. It was just more conservative stalling in the eyes of Adams. And any official rebuttal of the idea of independence could only undermine America's future position, which Adams understood to rest with independence. ${ }^{114}$ The document that the drafting committee produced was primarily the work of James Wilson. Adams came to realize that he had misunderstood Wilson -- he would not be the last to do so. ${ }^{115}$ Completed by February of 1776, it was titled "An Address to the

112 Reid, Age of the American Revolution, Vol. 3, 158-168.

113 Maier, From Resistance to Revolution, 198-227.

114 Burnett, Continental Congress, 60-62; Smith, Wilson, 74-76.

115 Smith, Wilson, 74-76. 
Inhabitants of the United Colonies.” Adams must have been relieved because it was no more a condemnation of the idea of independence than it was a promotion of it. The rhetorically thick, 6000-plus word document was nebulous in its handling of the two opposing positions. Conservatives were certainly disappointed in “An Address” as evidenced when the document was tabled and forgotten, surely to Wilson's irritation. ${ }^{116}$

"An Address" attempted to issue a consensus message by Congress to the people of the colonies, and in doing so, diffuse the confusion that many feared was gnawing at the foundations of colonial solidarity. But new factions had formed, and began to dominate Congress by 1775 . Anti-independence conservatives led by Dickinson and proindependence radicals led by Adams had no use for consensus messages to the public that did not strongly support their particular factional views. And "An Address” may not have served its purpose well in any case, because the document could itself be confusing. Congress was equivocating over the issue and “An Address" reflected the confused opinions of Congress too well to simplify the controversy for any common reader. It was perhaps Wilson's lone dialectic failure in the arena of written political controversy.

In "An Address," Wilson argued the justice of the colonial cause: "The Calamites which threaten us would be attended with the total Loss of those Constitutions, formed upon the venerable Model of British Liberty” he wrote. In this statement the committee reminded the reader of the threat to the colonial charters as well as the British constitution as a whole. They also direct the reader to the meaning of those constitutions -- "British Liberty."117

Perhaps answering Tory criticism, the committee added, "To avert those

\footnotetext{
116 Burnett, Continental Congress, 129-132.

117 Smith, Wilson, 75.
} 
Calamities we are under the Necessity of making temporary Deviations from those Constitutions.” It had long been the argument of British America's Whig opposition that they were dedicated to protecting the British Constitution against the caprice, first of an overreaching monarchy, and then of an overbearing Parliament. Colonials saw their charters as being extensions of that larger constitution and therefore constitutions in themselves. Liberty, of course, depended on the integrity of those constitutions and had to be defended. ${ }^{118}$ Yet, many Tories rebutted the Whig argument in the later phase of colonial struggle by pointing out that many opposition actions were technically unconstitutional. The opposition had, after all, set up extra-legal committees that usurped official governmental powers even within the purely local context. The Sons of Liberty that had evolved out of the Loyal Nine in Boston was an obvious example ${ }^{119}$ as was the burgeoning and ever more radical committee movement in Congress's host colony of Pennsylvania. And indeed, the Continental Congress itself could be cited as an unconstitutional institution! $!^{120}$

The standard Whig counter-argument was twofold. "Necessity” was part of the British Constitution. Legal precedence existed for justification by necessity in temporarily suspending laws and even constitutional forms. The argument for necessity had been made by the winning sides of both the English Civil War and the Glorious Revolution. It was particularly justifiable if the greatest possible good of the British Constitution, liberty itself, was at stake. ${ }^{121}$ It is important to note that the colonial Whig

\footnotetext{
118 Reid, Age of the American Revolution, Vol. 1: Authority of Rights, 160-168; Reid, Age of the American Revolution, Vol. 3, 111-117; Wood, American Republic, 265-274.

119 Hiller B. Zobel, The Boston Massacre (New York: W.W. Norton \& Company, 1970), 26-30.

120 Reid, Age of the American Revolution, Vol. 3, 28-29.

121 John Phillip Reid, The Concept of Liberty in the Age of the American Revolution (Chicago: The University of Chicago Press, 1988), 104-106; Reid, Age of the American Revolution, Vol. 3, 28-29.
} 
opposition claimed to be deviating from "those Constitutions" but never admitted to acting unconstitutionally. The second, potentially more radical argument, was based on a natural right of rebellion against injustice. This rationale was assumed to exist at the primeval root of the British constitution, the liberty it protected. ${ }^{122}$ The natural law foundations of the constitution were accepted in Britain as well as British America. To base the justification of American opposition solely on natural law, however, would have been unusual. Congress would not make such an argument until July of 1776. ${ }^{123}$ “An Address” referenced the earlier purely constitutional argument to justify extra-legal activity by the opposition.

Yet, perhaps most important was the committee's description of authority. Toward the end of "An Address" the power of Congress was justified with "the sacred Authority of the People, from whom all legitimate Authority proceeds." ${ }^{\text {124 }}$ Here, the committee moved beyond the representative ethic of the common law British Constitution. It is one thing to argue that legislatures must be elected by the people they tax to protect property and therefore liberty, quite another to say that "all legitimate Authority" must be founded on the people. The first is a constitutional check on legislative authority; the later implied a popular check on all forms of governmental authority. John Dickinson, in editing the committee's work tried to strike out the entire sentence, but Wilson was adamant about retaining it. ${ }^{125}$

\footnotetext{
122 Above quotes from Wilson et al, “An Address” in Wilson, Smith, 75. Also see Reid, Concept of Liberty, 25-27.

123 Burnett, Continental Congress, 184-187; David S. Lovejoy, “Two American Revolutions, 1689 and 1776" in British Revolutions, ed. Pocock, 258-259. Also see Thomas Jefferson, "Declaration of Independence" in The Life and Selected Writings of Thomas Jefferson, ed. Adrienne Koch and William Peden, (New York: Random House, Inc., 1972), 12-28.

124 Wilson et al, “An Address” in Wilson, Smith, 75.

125 Smith, Wilson, 74-76.
} 
Another curiosity of the statement is the use of present tense. The committee maintained that authority "proceeds" rather than proceeded from the people. Previous political philosophers and jurists from Hugo Grotius to David Hume and John Locke agreed that authority had historically or prehistorically been derived from human society. But in the case of Grotius and Hume, it was thought that when the people gave away power to government the transferal was permanent. Locke and his later followers Jean Jacques Burlamaqui and Emmerich Vattel, would suggest otherwise. This later cadre also argued that authority had been transferred from the People to governments at some earlier period. Yet, the transfer was not necessarily permanent. That transfer had been achieved through contract, and if any government broke that contract then the contract was dissolved and sovereignty returned to its original source, the People. ${ }^{126}$ The contract theory, of course, is the root of the natural law theory of rebellion that would find expression in the Declaration of Independence. It does not find expression in "An Address." What is significant is that the reference to popular authority in "An Address" suggests popular sovereignty as a contemporary root of authority rather than a historic one, contrary to the views of Locke, Burlamaqui and Vattel. ${ }^{127}$ Normally, a single verb such as "proceeds" would not be worth so much interpretation. But, considering the intellectual trajectory of the founding generation, the analysis is justified. The wording in "An Address" is representative of a growing new political concept among American Whigs in 1776. Throughout the colonies, in the struggle over independence, many began embracing the concept of a contemporary and un-transferable popular sovereignty. ${ }^{128} \mathrm{It}$

126 Jack P. Greene, The Intellectual Heritage of the Constitutional Era: The Delegate's Library (Philadelphia: The Library Company of Philadelphia, 1986), 13-18.

127 Ibid., 13-18.

128 Wood, American Republic, 362. 
also suggests that Wilson's thinking was moving ahead of many others in Congress, most notably John Dickinson's, and that Wilson was beginning to reject the idea of contractually transferred sovereignty as early as February, 1776.

The document's conclusion is that the goal of the colonies is the "Reestablishment of the constitutional Rights of the Colonies.” And that, though the colonies wanted to do so within the Empire, their first priority was "that America may be Free;" in other words, with independence if necessary. ${ }^{129}$

1775 was not an unusual time for ideological innovation. The entire eastern seaboard of British North America was undergoing a transformation in thinking. As Wilson worked on "An Address," Thomas Paine‘s Common Sense offered a newer more radical possibility to Americans. Paine whipped the whispered argument for independence into a flame that burned across the ideological landscape of the eastern seaboard. Through masterful polemics, Paine told Americans that the British constitution had never been perfect, or even worthy of affection, and that all monarchy was evil. Pure republicanism could work according to Paine, particularly in America. Common Sense filled the void that followed George III's rejection, and the American mind embraced it. The treason of the King and the impassioned plea of Thomas Paine would finally push a great number of Americans into a new vision. ${ }^{130}$ But a convinced people would have to cajole, threaten and pull their colonial governments and their Congressmen to the forefront. ${ }^{131}$

\footnotetext{
${ }^{129}$ Wilson et al, “An Address” in Wilson, Smith, 76.

${ }^{130}$ Bernard Bailyn, Faces of the Revolution: Personalities and Themes in the Struggle for American Independence (New York: Alfred A. Knopf, 1996), 67-84; Burnett, Continental Congress, 133-138; Foner, Tom Paine, 71-87; Ryerson, The Revolution is Now Begun, 152-155. Also see Thomas Paine, Common Sense (New York: Dover Publications, Inc., 1997).

131 Burnett, Continental Congress, 176-184; Ryerson, The Revolution is Now Begun, 202-208.
} 
Yet, even in the wake of popular acceptance of Common Sense, many in Congress were not convinced, and their reticence in taking up the cause of independence is understandable. Whether considered contracts or instruments, the constitutions that opposition Whigs had been defending were more than plans of government or sets of rights, they were bonds of association with Great Britain and her Empire. Dissolving that association meant, at least partially, dissolving those constitutions that Whigs in America had fought for so long to preserve. Independence aimed at a paradoxical goal of dissolving those constitutions to preserve the liberties that they had historically preserved. Whigs had also glorified the mixed nature of the British constitution. Monarchy, aristocracy and democracy, they told themselves, had been balanced to perfection in the King, House of Lords and Commons. The British constitution represented the height of governmental achievement and yet in the years after the Seven Years War something had gone terribly wrong. Parliament had become tyrannical. Some blamed the Ministry while making excuses for the king. ${ }^{132}$ Paine had tried to debunk the old Whig myth cycle of constitutional disintegration and reconstitution, but some like Dickinson continued to resist the lesson; it was a difficult vision for old Whigs to let go of even in $1776 .{ }^{133}$

Many who were radicals in the early 1770s because of their support for resistance to British parliament and support for colonial unity, became the new conservatives of 1775 and 1776. This transformation was what happened to John Dickinson and Thomas Willing. They did not revert to conservatism; rather, colonial radicalism had outpaced them in the debate for independence. Dickinson could not support independence though he continued to fight for the American cause outside of Congress. He clung to the hope

\footnotetext{
132 Ryerson, The Revolution is Now Begun, 155-175.

133 Paine, Common Sense.
} 
that a peace, advantageous to American rights within the Imperial structure, could be achieved. And he was not the only one. Most of the Pennsylvania delegation could not bring themselves to vote for independence when the time came. They would not agree to independence, even though Pennsylvania‘s Assembly rescinded the delegates’ original, prohibitive instructions, in a vain attempt at political self-preservation. ${ }^{134}$

Dickinson's refusal to embrace independence in 1776 temporarily cost him his political career in Pennsylvania, and the failure of the colonial Assembly to embrace it eventually led to the dissolution of the Assembly and the colonial charter of $1701 .^{135}$ Wilson's friendly association with the conservatives almost ended his career as well. In May of 1776, a radical committee of one hundred, supported by the militia and a majority of Philadelphians, voted to hold a constitutional convention to frame a new state constitution. Pennsylvania’s peaceful coup was partially enabled by John Adams who stealthily pushed a resolution through Congress that advised all of the colonies to support only governments that supported colonial rights. ${ }^{136}$ It was custom-made to undermine the Pennsylvania government that had so vocally opposed independence, and thereby terminate Dickinson’s conservative network. Wilson, understanding the resolution's import, tried to postpone it, saying that it placed the people of Pennsylvania “in a state of Nature.” For Wilson, his attempted postponement was not a conservative counter-ploy but proceeded from an honest fear of violent anarchy. ${ }^{137}$

Yet, radicals in Pennsylvania certainly saw Wilson's failed attempt at postponement as a betrayal. Responding to the angry reaction of Pennsylvania's radicals,

\footnotetext{
134 Smith, Wilson, 82-86.

135 Ryerson, The Revolution is Now Begun, 207-226.

136 Ibid., 207-226.

137 Burnett Continental Congress, 156-159; Smith, Wilson, 83.
} 
Congress produced an apology for Wilson entitled "In Defense of James Wilson.”

Suggestive of the respect that even radical Congressmen held for Wilson, it was signed by every member of Congress. ${ }^{138}$

On June 10, 1776 Congress passed portions of a pro-independence resolution proposed by Richard Henry Lee. Congress formed two committees -- one to consider a Declaration of Independence and the other to draft Articles of Confederation. But the definitive question of independence itself was postponed until July. ${ }^{139}$

As the date of the vote approached, Wilson asked that the vote again be postponed. The Pennsylvania delegation had not yet received the repeal of its earlier anti-independence instructions and Wilson wanted the postponement to wait for new instructions. Impatient radicals in Pennsylvania viewed this request as another betrayal. He was refused the postponement but, fortunately, the Pennsylvania Assembly's new instructions arrived before the vote. ${ }^{140}$

When Congress cast the vote to accept or reject the Declaration of Independence, Dickinson and Robert Morris refused to vote, while Charles Humphreys and Thomas Willing opposed it. James Wilson, John Morton and Benjamin Franklin, unshackled by a fearful Pennsylvania Assembly, supported it. By a slim margin, Pennsylvania‘s single vote was cast for independence. Wilson and Dickinson had parted ways, at least on the issue of independence. ${ }^{141}$

Of course, Wilson did not escape from the controversy of independence wholly unscathed. Regardless of bi-partisan support for him in Congress and his eventual

\footnotetext{
138 Smith, Wilson, 83.

139 Burnett, Continental Congress, 171-173.

140 Smith, Wilson, 83.

141 Burnett, Continental Congress, 182-183; Smith, Wilson, 83.
} 
support for independence, radicals in Pennsylvania had come to distrust Wilson. And it would be the radicals who controlled Pennsylvania after 1776, under their controversial constitution of 1776. Pennsylvania’s new radical Assembly returned Wilson to Congress in February of 1777 only because their first choice for Wilson’s replacement, William Moore had declined. ${ }^{142}$

During his first career as a Congressman, both before and after the independence controversy, Wilson proved to be an active member and a consistent populist. He was an active member of numerous committees including the Committee on Indian Affairs and, along with just four others, he served on the Board of War that oversaw military affairs. In the debates over the proposed Articles of Confederation, Wilson was one of those who campaigned for proportional representation by population in Congress, rather than equal state representation. And it was Wilson who made a failed motion, seconded by John Adams, to open Congress to the public. But, regardless of Wilson's energy or populism, radicals in Pennsylvania continued to dislike him. In addition, Wilson's behavior shortly after his return to Congress appears to have been fatalistic, as if he deliberately intended to commit political suicide. Perhaps he thought his removal from Congress was inevitable or his scruples necessitated a certain forwardness. Whatever the case, as soon as the radical Pennsylvania Constitution of 1776 was complete Wilson began to criticize it in public and in his correspondence. Reacting, the state Assembly removed Wilson from Congress in September of $1777 .{ }^{143}$ Wilson's first career as a continental statesman had come to an end.

\footnotetext{
142 Smith, Wilson, 102.

143 David McCullough, John Adams (New York: Simon \& Schuster, 2001), 140-141, 146-147; Jefferson, "Autobiography of Thomas Jefferson" in Life and Selected Writings ed. Koch \& Peden, 35-37; Smith, Wilson, 66-74, 107-110.
} 
Wilson’s first years in America were filled with excitement, transforming Wilson, as well as the North American continent. The majority of Europeans living on the eastern coast of North America convulsively turned from British Americans, dedicated to the mixed government of the British Empire, into Americans dedicated to creating lasting, pure republics. Amid all of the tumult, however, some consistencies can be found. Many political ideas, certainly those that had motivated the Revolution, remained an influence. A belief remained in the corrupting influence of concentrated, unchecked power, the requirement of constitutionalism and the centrality of positive rights, embodied in actual representation in government for the preservation of liberty. "Liberty" itself was, perhaps, the most important consistency. Whigs had tried to preserve the British constitution and the colonial charters to preserve liberty, but once the constitution proved too corrupt to preserve they embraced independence and pure republicanism to preserve liberty as well. So, if consistency counts for authenticity, the American Revolution would be better known as a "liberty revolution" than a "republican” or “constitutional revolution." Such was the spirit captured by Wilson when he wrote during the independence controversy that it was preferable to remain in the Empire, but if necessary, they would leave to secure their core goal -- "that America may be Free.” The preservation and even progress of "liberty" was the goal. First mixed government and constitutionalism, and then republicanism and constitutionalism were the tools that American radicals alternately depended upon to achieve the goal.

Of course, some were slower than others to accept that the preservation of liberty required independence and the construction of pure republics. Some would never accept this end at all and became Tories. Wilson certainly lagged behind the Adams's in the 
realization that independence was a necessity, but so had most in Congress. In the end, before the Declaration of Independence was voted on, Wilson had decided for independence. He probably had also come to think of sovereignty residing contemporarily and un-transferrably in the people at large by 1776, like many other American revolutionaries. ${ }^{144}$

${ }^{144}$ Dennison, “The "Revolution Principle”," 172-179. 


\section{CHAPTER III \\ WILSON: EVOLVING DEMOCRAT OR CONSPIRATORIAL ELITIST?}

Though a pivotal political figure of the revolutionary cause, Wilson's enemies in Philadelphia often reviled him as an aristocrat, even accusing him of being a closet Tory. Nothing could have been further from the truth. But Wilson's sloth in embracing independence had made him suspect, and his resistance to the 1776 Pennsylvania Constitution and the later price control movement nearly cost the statesman his life. As Wilson protested Pennsylvania’s constitution of 1776 from Congress, Pennsylvania became more factionalized over the issue. Anti-constitutionalists began to organize against the new constitution, proclaiming that their goal was to amend or replace the radical constitution. This movement took on the title of the "Republicans." In reaction, pro-constitutionalist forces rallied as the "Constitutionalists.”"145

The committees that seized control of Pennsylvania had depended on the support of the lower classes that were composed mainly of Presbyterians. These radical committees had been opposed by the older Quaker/Anglican political order that had controlled the colonial government under the charter of 1701 . The constitution that radicals designed in 1776 reflected the previous decade of struggle, and can be viewed as a logical outcome of those struggles. It was also one of the first new state constitutions following independence, and therefore one of the first constitutional experiments in pure republicanism in America. Like most of the new state constitutions, Pennsylvanians crafted their constitution of 1776 to maximize the powers of the assembly while 
minimizing the powers of the executive, but the radical Pennsylvanians took these precepts to extremes. The Pennsylvanians also tried to construct constitutional mechanisms to realize popular sovereignty in the highest echelons of the political process. $^{146}$

To assuage the lower class supporters of the radical cause, the state convention expanded suffrage in the new state constitution to include all adult, male inhabitants who had resided in the state for a year and had been assessed for any tax. Because of this innovation, the Pennsylvanian constitution is commonly thought to be one of the most democratic constitutions produced by the states, as it was then. Yet, the test oath, specifically designed to alienate the Quakers and their allies (Quakers considered the taking of oaths to be prohibitively impious), makes the overall democratic nature of that constitution questionable. The structure of government required by the constitution involved a unicameral legislature, a plural executive of twelve called the "Supreme Executive Council," and a "Council of Censors" to assemble every seven years with the option of remaining in session for a maximum of one year. ${ }^{147}$

The legislature proved the most dominant force in the government. Each county was equally represented in the assembly, but that would change after two years when a census was to be taken, after which representation was to be in proportion to population. The population of the counties would be re-assessed every seven years. ${ }^{148}$

\footnotetext{
145 Smith, Wilson, 110-115; Foner, Tom Paine, 135-138.

146 Ryerson, The Revolution Has Now Begun, 247-256; Wood, American Republic, 133-143, 169, 171172 ,

147 Pennsylvania, “Constitution of Pennsylvania -- 1776” in American Charters, Constitutions and Organic Laws, 1492-1908, Vol. 5, ed. Newton Thorpe (Washington: Government Printing Office, 1909), 30813092; Ryerson, The Revolution is Now Begun, 240-243.

148 Robert L. Brunhouse, The Counter-Revolution in Pennsylvania (New York: Octagon Books, 1971), 1214; Pennsylvania, “Constitution of Pennsylvania -- 1776”in American Charters, Volume 5, 3084-3086.
} 
The Pennsylvanian President was the chairman of the Supreme Executive Council. The Council was a plural executive that was elected by popular vote. But the Council's President was selected jointly by the Councilmen and the Assembly. The President could do nothing without the consent of his Council, and the whole executive was without a veto and nearly powerless to act without the express consent of the legislature. The Council appointed all non-elected officers, including judges who would sit for seven-year terms rather than during good behavior. ${ }^{149}$

In an attempt to institutionally realize popular sovereignty Pennsylvania radicals had established two political mechanisms aside from the popular election of key government officials. First, the legislature could not pass legislation into law without first publishing and distributing bills for public perusal and approval. Second, amendments to the constitution could only be made by special conventions elected by the People to make amendments. However, only the Council of Censors had the constitutional right to call for such conventions.

The Council of Censors would be popularly elected septennialy (one representative being sent from each county), to sit for one year and review laws already passed to determine their constitutionality. In this way, Pennsylvania radicals searched for a mechanism to counter-act the constitutional decay that they believed had come to corrupt the British constitution -- the Censors was their solution. If the Censors found a law unconstitutional then it became void. They could also call for special conventions to make amendments in the constitution. ${ }^{150}$

\footnotetext{
149 Brunhouse, Counter-Revolution, 14-15; Pennsylvania, “Constitution of Pennsylvania -- 1776” in American Charters, Volume 5, 3086-3088.

${ }^{150}$ Brunhouse, Counter-Revolution, 15-17; Pennsylvania, “Constitution of Pennsylvania -- 1776” in American Charters, Volume 5, 3091-3092; Wood, American Republic, 227-232.
} 
The Pennsylvania constitution of 1776 proved a clumsy instrument of government, particularly in times of emergency. And the sloth and impotence of the government that it created would only be exacerbated by the factional struggles that its passage initiated.

Analyzing votes in the Pennsylvanian Assembly along lines of wealth, regional affiliation and religion, historian O.S. Ireland has shown that religion was the most prevalent predicator of factionalism between Constitutionalists and Republicans on a state wide basis. The centrality of religious issues makes sense within the context of Pennsylvania’s history up to 1776 . The Anglican/Quaker alliance that had controlled colonial politics under the old charter had been ostracized from their dominant political positions in 1776. The radicals who replaced them under the new constitution of 1776 were predominantly Presbyterian, Calvinist and Lutheran, and had placed a test oath in the constitution that alienated Pennsylvania’s Quakers. Many still active Anglicans reacted by organizing opposition that coalesced into the anti-constitutional, Republican party. Republicans focused most on the test oath over the next thirteen years of factional strife. ${ }^{151}$ Of course, not every Republican was an Anglican or Quaker. Exceptions existed such as James Wilson, who was a Presbyterian, but the majority of core Republicans were certainly children of the older religio-political alliance.

Nonetheless, the religious and constitutional factionalists of Pennsylvania adopted other issues, either to bolster support for their factions or because their own convictions dictated that they promote an additional agenda. The issue of price controls provides an excellent example. In 1778-79, Pennsylvania, and particularly the artisans and laborers

151 O.S. Ireland, “The Crux of Politics: Religion and Party in Pennsylvania, 1778-1779” William and Mary Quarterly, 3rd Series, 42 (Oct., 1985): 455-469. Also see Wood, American Republic, 440. 
of Philadelphia, groaned under the pressure of run-away inflation. They demanded action and claimed that price-gouging Tory merchants were to blame. Their solution was price controls. The Constitutionalist legislature balked and the Constitutionalist Joseph Reed, by then President of Pennsylvania, thought the idea of price controls foolish. Nonetheless, in Philadelphia Constitutionalists like Tom Paine and Charles Willson Peale rushed to the common man's cause of price controls, eventually setting up an extra-legal committee to issue and enforce prices. These men may have had humanitarian convictions concerning price controls as poor relief, but many Philadelphia Constitutionalists saw price controls as a way to bolster support for their faction in the city. ${ }^{152}$

The factional issues of the Republicans and the Constitutionalists became even further complicated because elites in the respective factions often had additional scruples against the 1776 Constitution. Benjamin Rush despised the constitution on the grounds that it was too democratic and threatened anarchy in government. It was bad enough that most Republicans represented the dominant religio-political faction of pre-independence Pennsylvania, but when claims such as Rush’s came out of Republican meetings, Constitutionalists took full advantage of the anti-popular rhetoric. Constitutionalists pigeonholed Republicans as closet Tories and aristocrats. ${ }^{153}$

James Wilson’s complaint against the 1776 constitution was three fold. First, like almost every Republican, he focused on the unfairness -- the illiberality -- of the constitution's test oath. Second, Wilson complained that the various offices and powers

\footnotetext{
152 Foner, Tom Paine, 146-158.

153 Foner, Tom Paine, 135-137; Steven Rosswurm, Arms, Country, and Class: The Philadelphia Militia and the "Lower Sort" During the American Revolution, 1775-1783 (New Brunswick: Rutgers University Press, 1987), 123; Wood, American Republic, 441.
} 
of the constitution did not have the appropriate institutional checks and balances to guard against corruption. Wilson disliked the unicameral legislature and was particularly suspicious of the Council of Censors, which, in its yearlong session, would hold exceedingly great powers. The 1776 constitution was also, quite simply, impractical. Legislation was an exceedingly slow process and the septennial limitation on the amendment process was overly rigid. Unlike his friend and factional compatriot Rush, Wilson never argued that the 1776 constitution was too popular. ${ }^{154}$ Nonetheless, factional strife was no place for refined discernments. Wilson had taken up the mantle of a leading Republican partisan and his opponents labeled him an aristocrat for it.

Ejected from Congress and returning to his law practice in Carlisle, Wilson took a leading role in Cumberland County's anti-constitutional movement. Carlisle proved to be predominantly Constitutionalist. The hostile environment of Carlisle, combined with new business opportunities proffered by his friends in mercantile ventures, made the idea of returning to Philadelphia attractive. But Philadelphia had been occupied by the British in 1777. It would only be days after the British evacuation of Philadelphia in June 1778 that Wilson would sell his house in Carlisle and return to the city. ${ }^{155}$

Returning to Philadelphia, Wilson began arguing cases in the Courts. Wilson had become one of the most successful lawyers in Pennsylvania before he had entered Congress, and his reputation had not faded during his time in government service.

The people of Philadelphia had been enraged by the British occupation, and once the troops had gone, they turned their wrath against those in the city who were thought to be Tory. Wilson, believing that many of the "Tories" had been wrongfully accused,

\footnotetext{
154 Hall, Political and Legal Philosophy, 130-131; Pascal, Political Ideas, 205-207. Also see Pennsylvania, “Constitution of Pennsylvania -- 1776" in American Charters, Volume 5, 3091-3092.
} 
joined with like-minded lawyers George Ross and William Lewis to defend them. All of their defendants were accused of treason because they had aided the British during their occupation of the city. Many were neutral Quakers who had, like others, cooperated with the British when it was expedient. The defense attorneys put forth their best effort but in some instances an unfriendly, politicized jury (something that Wilson complained of more than once to the Court) found the accused guilty. ${ }^{156}$ It was a noble action, comparable to John Adam's defense of the British soldiers and an officer following the Boston Massacre, but most Tory baiters in the city surely did not see the behavior so benignly. ${ }^{157}$ Also, when the state of Pennsylvania seized the property of the Penn family under the divestment act of 1779, Wilson and his friends argued before the state assembly in favor of compensation for the Penns. So, Wilson's loyalties must have appeared suspect to the majority of people in Philadelphia -- certainly the agitated lower classes. ${ }^{158}$

Wilson also allied himself with his Republican compatriots on the issue of price controls in 1779. Republicans in Philadelphia formed a united voice against price controls, in defiance of the Constitutionalists and their extra-legal Committee of Trade. Merchants such as Robert Morris or men intimately involved in mercantile ventures such as Wilson made up the Republican leadership. ${ }^{159}$ They advocated free markets. Wilson had been an advocate of the ascending theory of self-regulating markets at least since 1774. In his revised Considerations...On Parliament, Wilson included a footnote at the end that anticipated criticism of his theory of confederated Empire. Because he had denied British Parliament the right to regulate American trade, Wilson understood that

155 Smith Wilson, 116-117.

156 Smith, Wilson, 118-123; Rosswurm, Arms, Country, and Class, 149-160.

157 Zobel, Boston Massacre, 220-221.

158 Brunhouse, Counter-Revolution, 79-80. 
some would think that he was arguing for anarchy in trans-Atlantic trade. Pre-supposing this criticism, Wilson rebutted, arguing that Atlantic markets could regulate themselves. “The stream of commerce,” Wilson had told the reader in 1774, "never flows with so much beauty and advantage, as when it is not diverted from its natural channels."160 Wilson agreed with Morris that inflation had been caused by the excess issuance of paper currency and not unscrupulous merchants operating within a British plot. But the rejection of price controls by Morris, Wilson and the Republican Society of Philadelphia must have made them appear to be cold aristocrats indeed, particularly in the eyes of desperate laborers -- a newly politicized class of men that dominated the militia. ${ }^{161}$

To understand Wilson's idea of progress, at least economic progress, it is necessary to understand that Wilson, at least partially, embraced a rising new ideology that contemporary historians have called "political economy." The tension that existed between this new ideology and older, traditional socio-economic ideas, that historians call "moral economy," acted as a force on both sides of the Atlantic. Historian Eric Foner demonstrated that the problems of 1779 Philadelphia were connected to this larger current and problem of civil development. For centuries, economic concerns had been merely another moral consideration of the community and part of the moral cosmos that the hierarchical structure of society was supposed to maintain. Certain economic arrangements existed in communities that most perceived to be beneficial to the good order of society. The common people had a right to these "moral economy" arrangements while their social betters had a duty to maintain them. An English example would be the maintenance of accessible, well supplied, farmer's markets that opened their

159 Foner, Tom Paine, 135-137; Rosswurm, Arms, Country, and Class, 194-199; Smith, Wilson, 116-117. 160 Wilson, “Considerations...On Parliament” in Works, Vol. 2, ed. McCloskey, 745-746. 
business for small buyers before allowing access to merchants. If farmers tried to sell their goods away from markets, or showed preference for bulk-purchasing London merchants, their communities might react violently to protect their eroded rights, particularly in times of dearth. ${ }^{162}$

As the eighteenth century progressed, moral economy and its national, imperialistic cousin, mercantilism, was ever more challenged by a rising philosophy of free-market trade and private self-regulation known as "political economy" or freemarket capitalism. This new manner of thinking about economics had been in development for at least a century before it found its most famous proponent in Adam Smith. It was a philosophy chiefly promoted by the merchant-dominated gentry of the British trans-Atlantic world. As it gained force among government officials the tension increased between supporters of political economy and moral economy, usually pitting gentry against commoner respectively. That tension was very observable in the political struggles of 1779 Philadelphia.

Wilson's economic thought was most influenced by the writings of James Stewart, another lowland Scot. Wilson's economic thought was nothing unusual because, until Adam Smith published Wealth of Nations, Stewart had been the most influential economist in America. In his Inquiry into the Principles of Political Economy, Stewart described an economy driven and stabilized by private credit. It was to be fiscal strength and expansive credit that could provide society with the surplus materials that it needed and wanted, not trade or price regulations. Yet, Stewart was no Smithian, or laissez-faire economist. With one foot still in the realm of moral economy, Stewart thought that

161 Rosswurm, Arms, Country, and Class, 66-108.

162 Foner, Tom Paine, 146-149; E. P. Thompson, “The Moral Economy of the English Crowd in the 
government had a role and duty in creating a powerful economy. It continued to be a moral duty of rulers to the broader community. He also feared a deficit of exports in comparison to imports, believing, like mercantilists, that specie would be drained away to the detriment of the state. But the best way to correct or guard against such trade deficits was to maintain a healthier economy than competitor states -- through credit. And the best way to promote credit and fiscal strength in the private sector was through strong banks, according to Stewart. Government's role was to be in helping these banks get started and lending them specie in times of economic stagnation. ${ }^{163}$

Wilson's thinking was identical to Stewart's, always insisting that strong credit created by strong banks was necessary for the material progress of the United States. And like Stewart, Wilson did not think that government interference with trade was wise, limiting government's role to the promotion and regulation of banks. It is therefore understandable why Wilson opposed price regulations in 1779 -- he thought the entire movement for price regulations foolhardy. It was an opinion that he was outspoken on, and it placed him, along with many others on a collision course with the lower classes of Philadelphia. ${ }^{164}$

The lower classes of Philadelphia suffered from rampant inflation in 1779. Grain and produce had been drained from the markets of Philadelphia by the demands of the Revolutionary war -- Continental Army troops, active militia and French troops had to be fed. Inflation had also been exacerbated by an excessive issuance of paper currency by the Pennsylvania Assembly. In addition, some merchants may have taken advantage of the situation to turn a profit, or at least, unintentionally deepened the economic crisis by

Eighteenth Century,” Past and Present, 50 (1971): 79, 83.

163 Smith, Wilson, 145-146. 
continuing to export. The merchants, nonetheless, were probably the lesser part of the problem, but in the view of laborers and small artisans in the city wealthy merchants were the chief cause. And as the economic crisis deepened it became difficult for the Pennsylvania Assembly to supply its troops. ${ }^{165}$

A popular cry went out for price controls to force merchants to sell at fair prices. The Assembly, though controlled by Constitutionalists, failed to pass price control regulation. Local Constitutionalists in Philadelphia, however, proved more receptive. Constitutionalists like Charles Willson Peale began to organize laborers, small artisans, and ultimately militiamen, into an energetic price control movement. Leading Constitutionalists formed a standing committee in May of 1779, known as the Committee of Trade. The Committee was to produce extra-legal price regulations, enforceable by either militia or civilian crowd action. Following the Committee's first proclamations, an angry crowd swarmed down to Philadelphia's market where they forced bakers and butchers to lower their prices.

On the other side of the Atlantic an unbroken tradition of crowds enforcing price controls onto sellers had long existed, particularly in times of dearth. These traditions provided a kind of customary law for crowd action and price controls in pre-industrial England. But no such traditions existed for the Philadelphians, who had never known similar economic hardships before the Revolution, so no spontaneous crowd actions occurred before the formation of the Committee of Trade in May. Legitimacy for crowd actions in Philadelphia could not be drawn from traditional law, but was to be drawn from popularly elected institutions like the Committee of Trade. For Englishmen, custom

\footnotetext{
164 Ibid., 147-154.

${ }^{165}$ Foner, Tom Paine, 149-150; Rosswurm, Arms, Country, and Class, 168.
} 
gave them the authority to riot; for Philadelphians in 1779, institutionalized popular sovereignty replaced that traditional force. ${ }^{166}$

Unfortunately for the radicals, the price control movement would never be as effective as it was energetic. As early as September of 1779, the Committee of Trade had dissolved indefinitely over internal divisions, and perhaps the realization that price controls could not be consistently enforced. Many merchants continued to defy the price ceilings that the Committee had mandated. ${ }^{167}$

Because inflation was hurting the war effort, many militiamen began to associate the apparent greed of certain wealthy merchants with Toryism. In October, frustrated militiamen seized four prisoners and paraded them in a rogue's march through the streets as Tories. Those paraded were all wealthy and suspect merchants, though none of them were members of the Republican Society, the local Philadelphian arm of the Republican Party. Objected to by Peale because of its rashness, the goal of the parade was to disgrace the intransigent merchants in front of the community. But a rumor had spread that the militiamen were after Wilson. Wilson himself had petitioned the Assembly for protection earlier in the day but was ignored. When the parade could not be diverted from moving up Chestnut Street, where Wilson lived, Wilson’s Republican allies thought that their worse fears had been confirmed. Between twenty to forty men ran ahead of the militia and, with their guns ready, awaited the anticipated attack of Wilson’s home. ${ }^{168}$

When the militia reached Wilson's house they continued marching -- they had not set out to attack any homes, not even Wilson's. But as the rear guard of the militia

\footnotetext{
166 Foner, Tom Paine, 165-169.

167 Foner, Tom Paine, 174-176; Rosswurm, Arms, Country, and Class, 184-205.

168 John K. Alexander, “The Fort Wilson Incident of 1779: A Case Study of the Revolutionary Crowd” William \& Mary Quarterly, 3rd Series, 31 (Oct., 1974): 593-604; Rosswurm, Arms, Country, and Class,
} 
column reached the front of the house a Wilson supporter yelled out from an upstairs window. An argument began and a shot was fired, though no one later could be sure who fired the shot first. The militia column stopped and came back toward the house to lay siege to it. The Republican partisans in Wilson's home had made their worse fears come true.

Wilson and his allies kept the militia at bay. The mob breached the house only once, and was then pushed out. The enraged militia commander, Captain Ephraim Faulkner, sent a small group to attain a cannon. Before the artillery could be brought, however, Pennsylvania’s Constitutionalist President Joseph Reed arrived and dispersed the militia at the head of a cavalry charge. Many of the militiamen were arrested but those who had defended Fort Wilson were allowed to go free. The Wilson defenders then marched in a victory parade through the streets. ${ }^{169}$

The militia riot has become known to history as the "Fort Wilson Riot" or "the Fort Wilson Incident” and it was the end of the price control movement. The riot stigmatized the issue of price controls, causing elites like Peale to separate themselves from it and the politicized laborers/militiamen on whom the Constitutionalists had depended. The removal of price controls and the lower orders from the factional arena opened Pennsylvania up for a sweeping Republican electoral victory seven years later after Robert Morris and James Wilson gave the Republicans an issue to finally win on -the Bank controversy. ${ }^{170}$

Robert Morris, Thomas Willing and James Wilson were among the creators and charter members of the Bank of Pennsylvania in 1780. They hoped that the bank would

209-214.

169 Alexander, “The Fort Wilson Incident”, 605-606; Rosswurm, Arms, Country, and Class, 215-217. 
establish credit that could be used to pay war expenses and stabilize the Pennsylvanian economy, all while turning a nice profit. Yet, the bank failed because the Constitutionalist dominated Pennsylvania Assembly refused to support it and withheld capital that Morris and his friends had depended upon. Constitutionalists feared the bank because Republicans controlled it and because such a large concentration of capital could be used to corrupt state politics. ${ }^{171}$ So again, Republicans and Constitutionalists divided on an economic issue, this time the bank issue. And again, the Constitutionalists had chosen the wrong side of history, but this time the ramifications would be more painful for them.

Small artisans had been an important group within the Constitutionalist ranks in the days of price controls. They had been hurt by rampant inflation and had pre-existing suspicions of their suppliers that were only exacerbated by accusations of price gouging. On the Bank controversy, however, small artisans began abandoning the Constitutionalists to support Republicans. Artisans agreed with Republicans that a bank could renew the energy of the Pennsylvanian economy. The Republican argument was powerful enough to win over radicals like Tom Paine but not the Pennsylvanian Assembly. As the 1780s progressed the Republicans gained political ground on the Constitutionalists while the Constitutionalist Party became marginalized as an anti-bank western party. ${ }^{172}$

The first bank, spearheaded by Robert Morris, Thomas Willing and James Wilson was supposed to be a temporary institution to raise funds for the war effort. It succeeded in raising money while the Pennsylvania Assembly proved incompetent to do the same.

170 Foner, Tom Paine, 178-182; Rosswurm, Arms, Country, and Class, 256-258.

171 Foner, Tom Paine, 194-195. 
All of a sudden the merchants, when operating through the bank, appeared to be the best friends of the Revolution. The Constitutionalists, dominating the Assembly appeared to be bunglers. The failure of the Constitutionalist dominated Assembly was instrumental in giving the Republicans a majority in the Assembly in 1781 .

After the first bank had dissolved, Morris and Wilson continued to strive for a more permanent bank. Morris took advantage of his position as Superintendent of Continental Finances to propose the idea of a national bank to Congress. Needing money, Congress agreed and granted Morris a charter in 1781. Wilson was made a member of the Board of Trustees and began borrowing money for his own land transactions. ${ }^{173}$

The elections of 1783 gave the Republicans a solid majority in both the Pennsylvania Assembly and the Supreme Executive Council. And John Dickinson, recently returned to Pennsylvania politics as a Republican, was selected as President of the Supreme Executive Council. Late in the previous year Wilson had served as an attorney for the state in a territorial dispute between Pennsylvania and Connecticut. Arguing before a special court established by Congress at Trenton, New Jersey, Wilson spearheaded Pennsylvania's legal team to win a noteworthy victory for his state. Soon after, the Republican majority in the Pennsylvania Assembly rewarded Wilson by sending him back to Congress as a delegate. ${ }^{174}$

Republicans also managed to gain a majority in Pennsylvania’s first Council of Censors in 1784. Predictably, they issued a call for a new constitutional convention, but Constitutionalists undermined the process at the county level and the convention never

172 Ibid., 184-203.

173 Smith, Wilson, 146-151. 
materialized. To many the Republicans had overreached by trying to call for a convention and, in 1785, Constitutionalists had regained a narrow majority in the Assembly. As a result, Republican and Constitutionalist bickering over the Republican controlled bank reached a new apex. Constitutionalists, once again in control of the Assembly, tried to repeal the Bank’s charter in Pennsylvania.

Wilson, still a member of Congress but also the Bank’s lawyer, argued in the Assembly and in print that the Pennsylvania Assembly could not repeal the charter. ${ }^{175}$ Through a broad interpretation of the second clause of the Articles of Confederation, he claimed that the power to establish the National Bank was implicit to the powers of the confederal government. After establishing the constitutionality of the bank, Wilson maintained that confederal law was implicitly superior to state law and that Pennsylvania could not repeal a Congressionally established institution such as the National Bank. In addition, Wilson pointed out that the charter of the bank was a contract, and it was contrary to common law that a legislature could dissolve contracts without due process. ${ }^{176}$ Moving from a legal argument, Wilson ended by describing the benefits of the bank to both Pennsylvania and the Confederation. ${ }^{177}$

Though Wilson’s argument was overwhelming, the Assembly, nonetheless, repealed the bank charter in Pennsylvania. But the evermore pro-bank electorate of the state would not prove forgiving. ${ }^{178}$ In the 1786 elections, Republicans enjoyed a massive victory and Wilson's continued career in Congress was assured. ${ }^{179}$

\footnotetext{
174 Ibid., 170-177.

175 Ibid., 150-158.

176 James Wilson, “Considerations on the Bank” in Works, Vol. 2, ed. McCloskey, 828-836.

177 Ibid., 837-840.

178 Smith, Wilson, 155.

179 Foner, Tom Paine, 203.
} 
Because of his caution in accepting independence, his outspoken criticism of the Pennsylvania constitution of 1776 and the price control movement of 1779, and legal defense of accused Tories, many in Pennsylvania thought of him as a pro-British aristocrat. But their prejudice against Wilson was unfounded. Wilson always proved to be, philosophically, a populist. And while others in the states grew reticent of the People between 1776 and 1787, Wilson was not one of them. As will be seen in Chapter 5, though Wilson saw first hand the wrath of the mob he was one of the most devoutly and consistently democratic delegates at the federal convention of 1787 . He remained optimistic that the people could govern themselves, and would play a key role in the next great American experiment in pure republicanism. 


\section{CHAPTER IV}

\section{$\underline{\text { WILSON THE CONTINENTALIST AND THE CONFEDERATION }}$}

The pan-state convention that met at Philadelphia in 1787 to suggest changes in the Articles of Confederation was the culmination of frustrations and fears that had been developing since before the Articles had gone into effect in 1781. When the problems of the Confederation continued to grow after the end of the war in 1783, the inefficiency of the confederal system could no longer be blamed on the tumults of war. And the inability of advocates for more centralized power to push amendments through the state legislatures, even during the post-war crisis years of the mid eighties, compelled them to revive the use of special conventions to solve the Confederation's governmental problems. Supporters of a stronger confederation grew until enough political impetus existed to form a working convention for reform in 1787 that represented every state but Rhode Island. This Constitutional Convention, as it would later be called, proposed an entirely new constitution that through popular ratification, became the federal Constitution of $1787 .^{180}$

Early in the Imperial and constitutional crisis that turned, finally, into a war for independence and republican revolution, James Wilson developed a continental

\footnotetext{
${ }^{180}$ Wood, American Republic, 354-361, 393-425, 471-518; Merrill Jensen, The Making of the American Constitution, (New York: Robert E. Krieger Publishing Company, 1964), 28-38.
} 
sensibility like many other veterans of Congress and the Continental Army. Still, among many in Congress and the states the continental spirit waned as the war dragged on, and was eclipsed by a new localism fearful of greater Congressional authority and the designs of other states. ${ }^{181}$ Wilson was not the victim of such an entropy of unifying spirit. His pan-state view was more constant and emphatic than that of many of his compatriots. So in 1787 Wilson would not need a fear of continental anarchy to revive his dedication to centralized, continental government. Consequently, his view of the purpose of the resultant 1787 constitution never had the decidedly conservative coloring that appeared in the thinking of some of the Founders.

Two facts of Wilson‘s life may explain his early continental disposition. First, Wilson was not native to his home state of Pennsylvania but had emigrated there from another region of the British Empire in young adulthood. Before independence he probably had a more cosmopolitan view of Pennsylvanians as subjects within an empire and after independence he naturally developed a broader view of Pennsylvanians as continental citizens. Second, Wilson was alienated from governmental politics in Pennsylvania through much of the war and was a leader of the opposition movement that antagonized the Pennsylvanian establishment. At one point a crowd that had, in his opinion, been misguided by Constitutionalist partisans, attacked his house. So to Wilson state politics were by no means inherently preferable to continental politics.

As early as 1777, in the debates over the Articles of Confederation, Wilson expressed a continental view to the chagrin of others who were already beginning to worry about the evolution of Congressional power. Along with John Adams, Wilson argued that Congress should approach the United States as a single political society rather

${ }^{181}$ Wood, American Republic, 464. 
than many. ${ }^{182}$ And as noted previously, Wilson advocated a proportional allotment of representation between the states in Congress based on population. ${ }^{183}$

Like at the Philadelphia Convention ten years later, the continentally-minded were most emphatically opposed by small state delegates who believed that their communities would be eclipsed if not absorbed by the larger states under a more centralized political structure. ${ }^{184}$ They demanded that representation of the states in Congress remain equal and that Congress be given as little power as possible. But the small state delegates were not alone in their distrust of Congressional power. It was Thomas Burke of North Carolina who added the finishing touch to the confederacy's decentralized structure in the Articles of Confederation. His amendment, passing against the lonely protests of James Wilson and Richard Henry Lee of Virginia, stated that

Each state retains its sovereignty, freedom and independence, and every power, jurisdiction and right, which is not by this confederation expressly delegated to the United States, in Congress assembled. ${ }^{185}$

When Congress finally agreed to the Articles in 1777, those who opposed centralized power and a national structure had won on every key point. The proposed Articles did not form a new nation but codified the loose military league of independent states that had already formed -- a league that would prove ever more fiscally inefficient as the war progressed. Though notably weak, distrust of Congressional power grew fast enough in the states that it would still take four more years for all the states to ratify the Articles. ${ }^{186}$

\footnotetext{
182 Ibid., 357.

183 McCullough, Adams, 140-141, 146-147

${ }^{184}$ Wood, American Republic, 355-362; Edmund S. Morgan, Inventing the People: the Rise of Popular Sovereignty in England and America (New York: Norton, 1989), 269-282; Jensen, American Constitution, 24-26, 44-56.

${ }^{185}$ Wood, American Republic, 358; United States, “Articles of Confederation, Article II” in American Charters, Vol. I, 10.

${ }^{186}$ Jensen, American Constitution, 24-25, 27-28.
} 
The Articles of Confederation divided legislative power between Congress and the legislatures of the states. Each state in Congress was to have a single vote, though contributions were to be in proportion to surveyed lands within any given state. And revenue bills had to be agreed to by the delegations of nine states in Congress and by all of the state legislatures before becoming law. Congress also needed better than a simple majority to exercise other key legislative powers. Without the assent of at least nine state delegations Congress could not,

engage in a war, nor grant letters of marque or reprisals...nor enter into any treaties or alliances, nor coin money...nor ascertain the sums and expenses necessary for the defense... of the United States, nor emit bills, nor borrow money on the credit of the United States...nor agree upon the number of vessels of war, to be built or purchased...nor appoint a commander in chief of the army or navy.

Amendments to the Articles, like revenue bills, had to be agreed to by both Congress and all of the state legislatures. ${ }^{187}$

As may be expected among a military league of states the Articles mandated comity between the states in numerous instances. "All privileges and immunities of free citizens" within any state including "free ingress and regress" and "all the privileges of trade and commerce" were to be observed in every state. Each state was to accept the judgments and records of other states with "full faith and credit.” In addition, states were forbidden to place imposts on goods moving from one state to another. They were also forbidden to form treaties with one another or any other nation, or wage war without Congressional consent. The states were to obey treaties "entered into by the United States in Congress." Unfortunately, the impotence of Congress made these regulations unenforceable. Though the Articles proclaimed that they should be "inviolably observed

${ }^{187}$ United States, “Articles, Article II” in American Charters, Vol. I, 10. 
by every State” there was no mechanism to realize the claim. The Confederation had no national executive or courts, or any express right to coerce individuals in the states or the governments of the states. ${ }^{188}$

When James Wilson returned to Congress in 1782 he found an inefficient and frustrated confederal government. Congress had consistently proven ineffective at paying and supplying their troops. In 1783, Congress moved to Princeton from Philadelphia, avoiding angry militiamen who had gathered outside the Pennsylvania State House. The troops disbanded only when they were told that Continental troops were on their way to route them. ${ }^{189}$ Later in the same year, near the end of the war, Congress's failure to pay troops nearly led to a general mutiny of the Continental Army at Newburgh, Pennsylvania. Numerous officers had decided to abandon Congress for the West if the war continued and march to force funds from Congress if the war was ended. If it had occurred, the mutiny would have probably ended the American experiment in pure republicanism with dictatorship. But the mutiny was diffused non-violently by the clever leadership of George Washington. Even Robert Morris and Alexander Hamilton dreamed of uniting civilian creditors and Army officers to achieve a coup d'etat, fortunately to no avail. ${ }^{190}$

Yet, a small but dogged cadre of men had developed inside and outside of Congress dedicated to making the confederation more effective by increasing the powers of Congress. The committee appointed by Congress in 1781 to put the Articles into effect (that included James Madison) had proposed appointing Congressional tax

\footnotetext{
188 United States, “Articles, Article II” in American Charters, Vol. I, 9-17.

189 Smith, Wilson, 189-193.

190 Douglas Southall Freeman, George Washington: A Biography (New York: Charles Scribner's Sons, 1952), 428-437; Jensen, American Constitution, 31; Smith, Wilson, 191-192.
} 
collectors and amending the Articles to give Congress the power to seize the property of states that refused to pay their assigned contributions. Congress ignored the proposals. ${ }^{191}$ Re-entering Congress in 1782, Wilson, always the continentalist, joined this group of centralizers. In 1783, with the support of Alexander Hamilton and James Madison, Wilson proposed an amendment to the Articles that would have increased the confederation's power significantly. It involved a general fund for disbursing the Confederation's debt to be raised by a general tax and collected by agents of Congress. To assuage fears of economic predation by one economic region against the other, Wilson included the suggestion of a compound tax on land and certain imported goods such as salt and wine that would distribute, he thought, the tax burden fairly among the states. The Wilson amendment was agreed to by Congress and sent to the states for ratification where it was defeated by the lone dissent of Rhode Island. Shortly after, Virginia repealed its initial acceptance of the Wilson amendment. The unanimity required by the Articles and a paranoid localism in the states made the confederation impervious to improvement. ${ }^{192}$

To fully appreciate the depth of Wilson's early support for continental government it will be productive to return to the bank controversy in Pennsylvania, already discussed in the previous chapter. The present goal requires a more involved description, however, and from a different angle of analysis. In 1785 a frustrated James Wilson pioneered a new potential way to increase the powers of the confederal government. He advanced his new doctrine within the context of the bank controversy

\footnotetext{
191 Jensen, American Constitution, 31.

192 Jensen, American Constitution, 28, 31-33; Rakove, Original Meanings, 23-28; Smith, Wilson, 179-182.
} 
between Constitutionalists and Republicans in Pennsylvania. ${ }^{193}$

Pennsylvania Constitutionalists distrusted the bank as a Republican tool to corrupt officials and electors, by which Republicans might usurp power in the state. The initiators of the idea of the bank and its key officials were Republicans after all, most notably James Wilson and Robert Morris. Congress had established a national bank and the Pennsylvania Assembly, under Republican control in 1782 provided a state charter for the bank. By 1785, however, Constitutionalists had won back the Assembly. They decided to repeal the state charter for the bank and declared that the national bank was unconstitutional. Both as a Congressman and a lawyer for, and stockholder in the bank, Wilson defended the institution publicly and before the Pennsylvania Assembly.

Wilson argued that the power of Congress to establish a bank was implied in the Articles of Confederation. Looking to Article II of the Articles of Confederation, he tackled those clauses guaranteeing state sovereignty and restricting Congress to powers “expressly delegated to the United States in congress assembled.” The power to establish a North American bank over all of the states had not existed in any one of the states, Wilson happily pointed out, so no such power could be delegated by the states. Therefore, the restrictive “express powers” clause in the second Article had no relevance to the issue of the Bank of North America. Continuing, Wilson contended that, Though the United States in congress assembled derive from the particular states no power... which is not expressly delegated..., it does not thence follow, that the United States in congress have no other powers..., than those delegated by the states. 194

Wilson cited Article V, that gave one of the purposes for Congress as "the more

\footnotetext{
193 James Wilson, “Considerations, On The Power To Incorporate The Bank Of North America” in Selected Political Essays of James Wilson, ed. Randolph G. Adams (New York: Alfred A. Knopf, 1930), 125-149.
} 
convenient management of the general interests of the United States.” So there were “more general rights, general powers, and general obligations, not derived from any particular states...but resulting from the union as a whole.” A North American Bank was necessary for "the general interests" of the confederacy, and yet the individual states had no power to institute one, so the power to institute the Bank became implicit in the powers of Congress. In concluding statements that must have chilled the blood of the more locally minded among Pennsylvanians Wilson declared that “To many purposes, the United States are to be considered as one undivided, independent nation...possessed of all...powers...by the law of nations incident to such.”195

Second, Wilson argued against the Pennsylvania Assembly’s power to dissolve the charter of the state bank. The state bank charter could not be repealed because it was a contract. It was not within the appropriate parameters of legislative power to be able to dissolve contracts. Rather, a firm and certain precedent existed in common law that contracts were under the jurisdiction of judicial review. For the Pennsylvania Assembly to arbitrarily repeal the charter would set a precedent endangering "the sure anchors of privilege and property,” exposing them to "every varying gust of politicks, and will float wildly...on the irregular and impetuous tides of party and faction.”196

Wilson’s argument of implied powers was an innovation, but his argument concerning the contractual nature of the state bank charter was not. Nonetheless, the Pennsylvania Assembly dissolved the state bank charter just as they publicly disavowed the national bank. ${ }^{197}$

\footnotetext{
${ }^{194}$ Wilson “Power To Incorporate Bank” in Political Essays ed. Adams, 131-132.

195 Ibid., 132.

${ }^{196}$ Ibid., 134-140.

${ }^{197}$ See Ch 3.
} 
Wilson's well organized and well reasoned argument of implied Congressional powers was the first meaningful argument for implied powers in American constitutional history. Within the Pennsylvanian context, his willingness to make such an argument shows a desperation to preserve an institution necessary for the stability and progress of Pennsylvania. Within the broader continental context, Wilson's ideas about implied powers show not only a desperation to preserve the Bank, but a strategy born of frustration to promote the powers of Congress. ${ }^{198}$

A doctrine of implied powers, accepted by the majority, may have succeeded in increasing the powers of Congress, bypassing the hopelessly difficult amendment process designated by the Articles. But it is questionable if the majority could have been convinced. Enough in Congress were convinced in regard to the Bank, but if the doctrine of implied powers had been extended to other issues it would have probably proved untenable. History will never know for sure whether it would have worked because those most dedicated to increased central power under the Articles never seriously tried to apply it outside of the Bank controversy. It is even uncertain how far Wilson would have been willing to push implied powers. The doctrine was not embraced by those trying to increase the powers of Congress for two reasons. First, most of the centralizers among the founding generation were also rigorous constitutionalists. They valued constitutions as necessary for the preservation of liberty; constitutions were instruments of the People that set parameters for government -- the delegates of the People. Those parameters only had value when observed and enforced, however, and a doctrine of implied powers could result in a soft constitutionalism in which the parameters were disregarded by those

\footnotetext{
198 Randolph G. Adams “Introduction” in Political Essays ed. Adams, 16-19; Jensen, American Constitution, 26.
} 
sophistic enough to style the right arguments. Implied power, in other words, could quickly slip into arbitrary power and a new parliamentary tyranny. The doctrine was too dangerous to use as a foundation of Congressional power. ${ }^{199}$

Second, another, safer way existed to by-pass the inane process of the Articles -the special convention. The special convention, drawing its legitimacy either from established and legitimate governments or directly from the People, was a method that must have appeared conservative if not strictly constitutional in every instance by 1785 . It had been used repeatedly by British American opposition Whigs and then revolutionaries during the war. Indeed, Congress itself had begun as a (presumably temporary) convention of state delegates. And most of the leadership in the United States had earlier either involved themselves with special local conventions or been a part of committees that acted on their recommendations. Even before the Articles had been ratified, in the four years that they hung in legal limbo, some had suggested special conventions to solve the impasse over the Articles. So it was not unusual that frustrated supporters of Congressional power embraced the idea of a special convention to agree on alterations in the Articles. $^{200}$

As early as 1783, an irritated General George Washington, fretting over the condition of his troops, had suggested an amending convention to alter the Articles. In the same year that Wilson was arguing implied powers in Pennsylvania, the legislature of Massachusetts suggested a convention for amending the Articles to Congress, but the suggestion was rejected. ${ }^{201}$ And at a convention of officials from Maryland and Virginia to resolve navigation disputes at Mount Vernon, a proposal was made to have a more

\footnotetext{
199 Adams, “Intro.” in Political Essays, 19; Jensen, American Constitution, 26.

200 Jensen, American Constitution, 33; Wood, American Republic, 310-319, 532-536.
} 
general convention of the states at Annapolis in the following year to discuss continental economic and trade policy. The Annapolis Convention in 1786 would only be attended by delegates from five of the states but would produce an influential proposal for a convention to modify the Articles of Confederation at Philadelphia, in 1787. It was the seed of the Constitutional Convention. ${ }^{202}$

Yet, the precedents of special conventions and the impossibility of reform under the Articles cannot alone explain why the American leadership sought a more powerful central government or why they achieved it in 1787. Special conventions and a defunct amendment process only formed the parameters of their activity, the impetus of their success lay in a political will for stronger central government that steadily increased among Americans throughout the period. Fear was the foundation of that will.

The situation of the states, individually and as a confederation, appeared more and more dire to the American leadership. As the 1780s progressed, it appeared to many that the thirteen American experiments in pure republicanism were on their way to selfdestruction and were about to take property, the foundation of liberty, to hell with them. ${ }^{203}$ Though the revolutionary generation had chosen to embrace pure republicanism as the surest security for American liberty, they understood pure republics to be at special risk. Republics were the best form of government for the maximization of liberty because, being based immediately on the general community, they responded better to the needs of the general community. But republican government was also the weakest because it might respond to the community's irrational whims. In the long run, only an

\footnotetext{
201 Jensen, American Constitution, 33.

202 Jensen, American Constitution, 33-34; Rakove, Original Meanings, 28-34; Ralph Louis Ketchum, James Madison , A Biography (New York: The MacMillan Company, 1971), 185-189.

${ }^{203}$ Wood, American Republic, 395-425.
} 
essentially virtuous people could sustain a pure republic and its greater liberty. Though some vice might be inevitable and non-catastrophic and institutional checks might be erected to counter-act vice, an excess of popular vice would always lead to the failure of a republic. When vice ran amok the people divided into antagonistic factions, sacrificing the good of the whole for their own narrow gains. The inevitable result would be the dissolution of a republic, resulting in the arbitrary rule of the strong. ${ }^{204}$

Before the revolution, British Americans would have argued that the mixed constitution of Britain was better than any hypothetical pure republic for the prolonged promulgation of liberty, because the weakness of republics condemned them to short lives ending in tyranny. Partially republican, the British constitution sustained liberty through representation of the Commons in Parliament. Partially aristocratic and monarchial, it provided stability and long-term security for the liberty that Britons enjoyed. Stability came from the counterbalance of three distinct classes of society in Britain, each institutionally represented in government -- the monarchy found in the Crown, the nobility found in the House of Lords and the commoners found in the House of Commons. ${ }^{205}$

But most of the Americans who fought British aggression had, by the late 1770s, rejected the perfection or even the basic propriety of the British constitution. They became convinced that Britain's mixed constitution had never worked the way it was supposed to work or was corrupted beyond repair. Equally important, they became convinced that pure and lasting republicanism was plausible in America. The American people were virtuous enough. And many Americans came under the influence of a new

\footnotetext{
204 Wood, American Republic, 422-425, 448-478.

205 Wood, American Republic, 197-214, 222-244.
} 
school of governmental thought, most effectively discussed by the philosoph Baron de Montesquieu, that balanced powers could be effectively established in government even when countervailing institutions did not represent distinctive and opposing classes within society. ${ }^{206}$ America did not have the hereditary class of aristocrats to build a mixed constitution in any case. Yet, in the later phase of the war and in the years following, American virtue and class-disassociated balances of government in the states did not seem to be doing so well. ${ }^{207}$

By the mid-1780s the highly inflationary post-war economy pitted debtors and creditors against one another. Many state legislatures made inflation worse by producing too much paper money to assuage anxious debtors. In some states crowds of debtors had threatened officials and shut down state courts to prevent judicial proceedings against them. To ease the pressure on debtors many legislatures began to over produce paper currency, purposely driving down the value of currency. Security of property itself seemed threatened by state legislators who spoke loosely of forgiving debts, effectively dissolving contracts between creditors and debtors. Wilson had experienced this kind of arbitrary parliamentary power with the dissolution of Pennsylvania's state bank charter in 1785. When government arbitrarily dissolved contracts no security for property existed, and no security for liberty could be maintained as a result. ${ }^{208}$

Congress could not solve its own problems much less help the states. Congress, unable to draw sufficient funds from the states, faced a gigantic war debt. And in the tense economic and political environment of the mid-1780s, various states also began to

\footnotetext{
${ }^{206}$ Greene, Delegate’s Library, 43-44; Wood, American Republic, 237-255.

${ }^{207}$ Edward Countryman, Americans: Collision of Histories (New York: Hill and Wang, 1996), 66-73; Wood, American Republic, 396-425.

${ }^{208}$ Morgan, Inventing the People, 266; Reid, Concept of Liberty, 68-73; Wood, American Republic, 396-
} 
violate the Articles only to underline the impotence of a Congress that could do little more than verbally admonish them. Some states placed tariffs on each other's goods, made treaties or contemplated making treaties with foreign powers and violated the earlier Congressional peace treaty with Britain, all in violation of the Articles and the will of Congress. ${ }^{209}$

The result was a growing chorus of fearful men agreeing with continental thinkers like Hamilton, Madison, Wilson and Washington that the powers of Congress had to be increased. Chances of an amendment to the Articles attaining the unanimous consent of the states continued bleak however, and in 1786 an amending convention was suggested by the convention at Annapolis. Congress publicly supported the Philadelphia Convention, mandating that it would propose amendments for the Articles to Congress for consideration. A final, catastrophic event occurred that provided additional support in the states for the convention because it seemed to confirm the fears of those who wanted to increase the powers of Congress. In January, 1787 an ex-Continental Army Captain, Daniel Shay, led a large rebellion in Massachusetts that had to be suppressed violently by the state militia. The rebellion probably convinced many states to participate in the convention that would not have otherwise sent delegates. When the Philadelphia Convention convened in May, 1787 all the states but Rhode Island would send delegations. Wilson, the continental nationalist, would play a central role in the convention. $^{210}$

425.

209 James Madison "Preface to Debates in the Federal Convention” in James Madison, The Debates in the Federal Convention of 1787, ed. Adrienne Koch (New York: W.W. Norton \& Company, 1966), 6-16.

${ }^{210}$ Jensen, American Constitution, 34-39; Ketchum, Madison, 186-192. 
CHAPTER V

WILSON AT THE 1787 CONSTITUTIONAL CONVENTION

The federal constitution of 1787 did not create a purely national political structure out of the thirteen states, but one that was partly national and partly federal and placed significantly greater power in the central government of the United States than had the earlier Articles. ${ }^{211}$ The new central government realized the principle of popular sovereignty by mandating immediate popular elections of the House of Representatives, possible mediated popular elections of the President, popular ratification of the constitution by special convention and the option of popular special conventions to ratify future amendments to the constitution. ${ }^{212}$ Some may have also thought that popular

${ }^{211}$ Madison, “Republicanism, Nationalism and Federalism” or "Federalist, Number 39" in The Federalist Alexander Hamilton, James Madison and John Jay, ed. Benjamin Fletcher (New York: MetroBooks, 1961), 280-286; United States, “Articles" and "United States Constitution" in American Charters, Volume I, 9-28. 212 United States, “United States Constitution”, 19-28. 
sovereignty had been realized through the continuation of notable powers in the hands of the state governments. Many American leaders presumed states to be more representative of the people because of their greater locality. The hopeful result of greater locality was a greater intimacy between state representatives and the represented. ${ }^{213}$ Though on this last point James Wilson certainly would not have agreed.

During the Philadelphia Convention Wilson proved to be as continentally minded as his Virginian contemporaries and even more dedicated to populism in government, to the point of being a true democrat. The proposed constitution that the Philadelphia Convention produced would not be as free from state interference or as democratic as Wilson wanted, but he considered it sound enough in its functions and underlying principles to become one of its leading advocates during the contest for ratification. Three years after Pennsylvania ratified the new federal constitution Wilson led a constitutional convention to frame a new constitution for the state similar to the federal one. Throughout this transformative period Wilson rejected Lockean contractualism in favor of a democratically instrumental understanding of constitutionalism within a national United States.

Set for May 14, 1787, not enough delegates had appeared from the various states to begin the Philadelphia Convention until May 29. Nonetheless, the delegation from Virginia arrived early and well prepared, James Madison being at the core of their preparedness. Madison had dedicated himself to studying the history of confederations to prepare for the convention, and was already a highly experienced continental statesman who had been struggling to increase the powers of Congress for years. Madison had designed a general blueprint for a wholly new central government. It would be strong to

213 Morgan, Inventing the People, 44-45, 244-245, 279-280. 
solve the problems of Congressional weakness, republican to perpetuate American liberty, and involve mechanisms of institutional countervalence and filtration to insulate the new government from both magisterial and popular vice. ${ }^{214}$

James Wilson, by this time a veteran Congressman and continentally renowned lawyer, arrived at the Convention on May 25th with the rest of the Pennsylvania delegation. It had been little more than a month since his wife Rachael died. As the delegates descended on the Pennsylvania State House in May, Wilson and his six children were still in mourning but sorrow was not going to keep Wilson away. ${ }^{215}$ His appearance underlines the weight that Wilson understood the event to have.

A quick analysis of the debates of the Convention will make apparent Wilson's sincere dedication to continental nationalism and popular sovereignty. No evidence suggests that Wilson involved himself in a special study of confederations leading up to the Convention as did Madison. But Wilson had dedicated his life to the study of law, government and its philosophy as few others had. Throughout the Convention Wilson repeatedly supported Madison’s vision for a national federal government free from state domination, proportional representation in Congress, a joint executive-judicial veto over federal legislation, a powerful federal judiciary and ratification of the proposed constitution by special popular conventions. Occasional disagreements appeared between the two statesmen but their disagreements were never divisive, and the fundamental principles that they operated from were alike. Both of them embraced popular sovereignty, pure republicanism, institutional counterbalances based on function rather

\footnotetext{
214 Ketchum, Madison, 188-195; Madison, "Preface” in Debates, 28-33; James Madison, “To George Washington, 16 April 1787” in The Papers of James Madison, Volume 9, ed. Robert A. Rutland (Chicago: The University of Chicago Press, 1975), 383; Read, Power vs. Liberty, 25-29, 47-53; Wood, American Republic, 499-528.
} 
than class and the concept of a national American people. Yet, on at least one fundamental point Madison and Wilson diverged.

Madison believed that the people had to be protected from their own passions. The "republican remedy" to popular irrationality was institutional "filtrations" of the popular will and the propagation of inherent political friction in the legislative process. Achieving an appropriate amount of filtration would require, among other things, putting some legislators one step away from the people by having them appointed rather than elected, and extending the terms of office for legislators and other magistrates to insulate them from temporary public clamor. Conservatism could also be achieved by "expanding the sphere of representation," allowing for so many factions that one could not dominate the governmental process thereby slowing changes and preventing extremism in policy. A bicameral legislature would also increase conservative policymaking, specifically in the legislative process. ${ }^{216}$

This way of thinking was alien to Wilson. Wilson's concern with corruption during the Convention focused solely on magisterial corruption. The corruption of those who held power was to be checked through the counterbalance of independent and functionally limited branches of government as well as a counterbalance between the new federal government and the states. Wilson trusted the general populace more than did Madison, and never admitted the existence of representatives between the people and governmental policy to be a positive good. So when Madison proposed that representatives in the lower camera of the legislature have terms longer than one year,

215 Smith, Wilson, 210-214.

216 Madison, Debates, 40-41, 75-77; Read, Power vs. Liberty, 47-51, 89-91, 113-114; Wood, American Republic, 466-467, 499-528. 
Wilson came out against it. ${ }^{217}$ However, Wilson supported the idea of Senators having six-year terms, but for very different reasons than did Madison. Madison wanted Senators to have longer terms and be elected in staggered elections to insulate the Senate from popular passions and facilitate conservatism in the body. New Senators would enter a body in which one third of its members had already been there for two to four years. Wilson saw the extended terms of the Senators as a necessity to gain the respect of prejudicially aristocratic foreign powers that would, he thought, be dealing with the Senate. Staggered terms would also facilitate a more informed handling of diplomatic affairs over time but allow for the entry of fresh approaches into the institution. ${ }^{218}$ Representation was, for Wilson, an incidental attribute of free government necessitated only by the largeness of population. Wilson put this populist point of view best himself:

Vigorous authority (ought) to flow immediately from the legitimate source of all authority. The Government ought to possess not only the force, but the mind and sense of the people at large. The legislature ought to be the most exact transcript of the whole Society. Representation is made necessary only because it is impossible for the people to act collectively. ${ }^{219}$

Fortunately for Wilson and Madison, who often looked to each other for support during the Convention, their philosophical differences never led to a breach between them. Their historical situation allowed them to sidestep their differences over the precise reliability of the “people at large.” They were faced with greater worries, by men who resisted the centralization of power or the realization of other fundamental principles in

\footnotetext{
217 Madison, Debates, 169.

218 Ibid., 193-198.

219 Ibid., 74.
} 
the new federal structure that Wilson and Madison did hold in common. ${ }^{20}$

When the business of the convention opened, Edmund Randolph proposed Madison's plan for the Virginia delegation. What historians have come to call the Virginia Plan envisioned a highly nationalistic government with representation in a bicameral Congress, proportionally distributed between the states, based on either free population or annual contributions. Congress would have the power to lay and collect taxes from individuals in the states as well as enforce federal laws on individuals in the states. Congress could veto state legislation that contradicted the new federal constitution to ensure comity among the states. Congress could also establish an army and a navy that could be used against intransigent states. The people would elect the lower house for an unspecified term and the lower house would select the members of the smaller, upper house for an unspecified term. ${ }^{221}$

Madison proposed a "National Executive” selected by Congress for an unspecified term, “to execute the National laws...(and)...enjoy the Executive rights vested in Congress.” The executive, together with members of the "National Judiciary," would form a Council of Revision that could veto federal legislation that it considered unconstitutional, though the veto could be overridden by a second Congressional vote. The "National Judiciary" was to be appointed by Congress "to hold their offices during good behavior.” The high court was to have jurisdiction over federal impeachments, cases “of a dernier sort,” cases involving international waters, and cases involving two or more states or parties from two or more states. And the plan called for inferior courts

220 Read, Power vs. Liberty, 89-91, 113-114.

221 Ibid., 30-31. 
with local jurisdiction over federal cases in the states. ${ }^{222}$

Madison’s plan guaranteed "Republican Government” to the new states that would soon be culled out of the western territories. An amendment process existed to be used "whensoever it shall seem necessary, and that the assent of the National Legislature ought not to be required.” The final resolution of the plan called for ratification by special conventions following Congress's approval. ${ }^{223}$

The Virginia Plan expanded the perceived mission of the Convention, turning it from an amendment convention into a constitutional convention. A few resisted while most at the Convention accepted the idea that proposing revisions could also mean proposing a complete replacement of the old Articles. On May 30 Charles Cotesworth Pinckney of South Carolina and Elbridge Gerry of Massachusetts voiced doubts that the Convention had the authority to make such radical suggestions. The convention ignored them, their suggestions going unanswered in Madison's notes. Neither did the two men breach the issue again -- others would however. Frustrated small state delegates, led by William Paterson, used the idea that the Convention was overreaching its bounds as an excuse for presenting their own counter-plan, known to posterity as the "New Jersey Plan.” Paterson's plan gave more powers to Congress but representation in Congress would continue to be equal among the states and would be appointed by the state legislatures, as it was under the Articles. ${ }^{224}$ Paterson put it flatly when he said,

A federal compact actually exists, and consult the articles of it we will still find an equal sovereignty to be the basis of it. No alteration shall be made without unanimous consent. This is the nature of all treaties. If the sovereignty of the states is to be maintained, the Representatives must be drawn immediately from the States, not from the people: and we have no

\footnotetext{
222 Ibid., 31-32.

223 Ibid., 32-33.

${ }^{224}$ Ibid., 118-119.
} 
power to vary the idea of equal sovereignty. ${ }^{225}$

Wilson immediately took up the task of answering Paterson. He drew from the same doctrine of moral necessity that he and other opposition Whigs had drawn on in the controversy with British Parliament. In the interest of preserving liberty, necessity could allow temporary variations from common law norms or contractual requirements -radical committees were justified in 1774 using such arguments, and it was why the activity of the Convention was justified in $1787 .{ }^{226}$ In addition, Wilson "conceived of himself authorized to conclude nothing, but to be at liberty to propose anything.” It was a fine but important point. Charles Pinckney of South Carolina and Randolph of Virginia echoed Wilson. "When the salvation of the Republic was at stake" Randolph argued, "it would be treason...not to propose what we found necessary.,227

The eventual product of the Convention was very different from the Virginia Plan, but the influence of the Plan's outline and underlying assumptions on the federal Constitution of 1787 is evident. The similarities between the two can be attributed to the fact that the Virginia Plan dominated the format of the entire Convention, the mischievous (as Madison and Wilson doubtlessly thought of it) New Jersey Plan not withstanding. Moving from resolution to resolution in the Virginia Plan, the delegates discussed and voted on each one. As changes were made the resolutions were re-drawn to reflect the changes and discussed again.

Resolutions dealing with the legislature cultivated the first formative debates. Election of legislators and the distribution of representation, particularly in the Senate,

\footnotetext{
225 Ibid., 123.

226 Ibid., 123. Wilson's argument of necessity is not actually supplied by Madison, but it is implied by Paterson's attempted rebuttal in which “Mr. Wilson” is specified.

227 Ibid., 125-127.
} 
drew heated and intricate debate throughout the Convention, filling more space in Madison's notes than any other single issue. It was in these debates that Wilson exerted most of his efforts, as a passionate advocate of popular election, liberal suffrage and proportional representation in both legislative houses.

On May 31, Gerry of Massachusetts and Roger Sherman of Connecticut "opposed the election” of the lower house "by the people.” "The evils we experience” Gerry exclaimed, came "from the excess of democracy." He went on,

The people do not want virtue, but are the dupes of pretended patriots. (Gerry) was still however republican, but had been taught by experience the danger of the leveling spirit. ${ }^{228}$

George Mason of Virginia rebutted, playing upon notions of mixed constitutionalism -here is evidence that, even in 1787, the last vestiges of that antiquated way of thinking continued to be habitual for some. Mason maintained that the lower house ought to be directly chosen by the people because it was "to be the grand depository of the democratic principle -- our House of Commons.,229

Wilson rebutted Gerry and Sherman without references to mixed government.

His comments predicate Wilson's spirit throughout the Convention. Madison wrote that Wilson,

contended strenuously for drawing the most numerous branch of the Legislature immediately from the people. He was for raising the federal pyramid to a considerable altitude, and for that reason wished to give it as broad a basis as possible. No government could long subsist without the confidence of the people. In a republican Government this confidence was peculiarly necessary. He also thought it wrong to increase the weight of the state legislatures. ${ }^{230}$

On the same day, the debate moved to the selection of members of the upper house, that

228 Ibid., 39.
229 Ibid., 39. 
would eventually be the Senate, and Wilson took a populist stand again.

Wilson opposed selection of the Senate by either the states or the lower house, as suggested in the Virginia Plan, because the Senate "ought to be independent of both.” He contended that "both branches of the National Legislature ought to be chosen by the people.” Otherwise "the two branches will rest on different foundations, and dissentions will naturally arise between them.” Anticipating a problem between proportional representation for the large population of America and the desirable smallness of the Senate, Wilson suggested that special large districts could be drawn, transcending the borders of the states, for the election of Senators. Madison protested Wilson's idea. “Such a mode” Madison argued, “would destroy the influence of the smaller States associated with larger ones in the same district.” It was an odd argument for the Virginian to make considering later arguments between him and small state delegates over the need for mutual trust between large and small states. ${ }^{231}$

Wilson then butted heads with his old mentor in law, John Dickinson, who had been sent to the Convention from Delaware. Dickinson must have been surprised by Wilson's stance on the election of the Senate, and the argument between Dickinson and Wilson over popular election quickly became a heated discussion over the nature of America's impending federalism. Dickinson favored selection of Senators by the state legislatures. The state legislatures would make better choices than the people, Dickinson thought. The Senate should "consist of the most distinguished characters" and bear "as strong a likeness to the British House of Lords as possible.” He also wanted state selection of Senators because "the preservation of the states in a certain degree of agency

\footnotetext{
230 Ibid., 40.

231 Ibid., 42, 82.
} 
is indispensable.” He spoke allegorically that the various states were like planets. The confederacy was a solar system and the planets "ought to be left to move freely in their proper orbits.” He accused Wilson of wanting “to extinguish these planets.” ${ }^{232}$ Wilson answered his mentor that,

the British Government cannot be our model. We have no materials for a similar one. Our manners, our laws, the abolition of entails and primogeniture, the whole genius of the people, are opposed to it.

Adopting Dickinson's allegory, Wilson observed that just as the planets are subordinate to the sun, so should the states be subordinate to the central government. And it would not be the states that would be "devoured" by the new federal government. "On the contrary" he demanded, "he wished to keep them from devouring the national Government.” But Dickinson’s caution won the Convention over in the end, and they voted in favor of his proposal. ${ }^{233}$

Even after he knew that Senators would not be popularly elected, Wilson continued to promote proportional representation based on population for the Senate. In early arguments with Paterson over proportional representation, Wilson took a truly democratic and passionate stand over proportionality in the legislature. Proclaiming that "all authority was derived from the people” Wilson demanded that " equal numbers of people ought to have an equal number of representatives." "This principle had been improperly violated in the Confederation" that Paterson wished to imitate, "owing to the urgent circumstances of the time." Paterson had claimed that "New Jersey will never confederate on the plan before the committee." Wilson countered that "Pennsylvania and...some other States, would not confederate on any other" and that "if New Jersey

\footnotetext{
232 Ibid., 82-84.

233 Ibid., 85-87.
} 
would not part with her sovereignty it is vain to talk of Government."234

However on the following day, June 11, Roger Sherman of Connecticut proposed that the lower house have proportional representation while the Senate would have equal representation between the states, as a compromise to break the impasse between the large and small states. Wilson, with Alexander Hamilton of New York, made a counterproposal "that the right of suffrage in the 2nd branch ought to be the same rule as in the 1st branch.” And it was agreed to but Wilson's victory regarding the Senate would be short lived. Oliver Ellsworth of Connecticut was re-galvanizing Paterson's small-state block around the idea of equal suffrage in the Senate as a necessary compromise. Wilson, along with Madison, would struggle vigilantly to the end to avoid such a compromise. ${ }^{235}$

When the issue of equality in the Senate reached a heated stalemate on June 29 and 30, Wilson warned that if equal representation of the states was allowed in the Senate the "minority (would) controul in all cases whatsoever." "Is it for men" that they were forming a government, Wilson sarcastically asked, “or for the imaginary beings called States?” If the legislature of the new government was not laid upon the appropriate principles of popular suffrage, Wilson warned "it can be neither solid or lasting.” Madison sided with Wilson, saying that a majority of states might obstruct and "extort measures repugnant to the wishes and interests of the Majority" of the People. Striking at the factional assumptions of the small-state delegates, Madison made a prophetic statement to a twenty-first century observer. If "great divisions of interest in the United States" developed it would be between "the Northern and Southern" not the

\footnotetext{
234 Ibid., 97-98.

235 Ibid., 98-104.
} 
small and large states. Madison’s speculation was ignored and Ellsworth simply denied that the minority would dominate the majority through the Senate. Rather, Ellsworth claimed, the Senate would be a defense for the minority. ${ }^{236}$

On the heels of this exchange between the two blocks, William Richardson Davie of North Carolina pointed out that if proportional representation were to be had in the Senate, the senatorial body would have to be very large. A large Senate ran contrary to the desire of the majority in the Convention including Wilson, that the Senate was to be small, or at least smaller than the House. The Senate was supposed to be a more conservative body to stabilize the legislative process and deal more consistently with foreign powers. The smallness of the body was supposed to result in greater conservatism, either because it filtered the factional interests of the people into a few representatives who would then have to consider all factional perspectives or because fewer men would have more intimate professional relationships. ${ }^{237}$

Wilson admitted that the problem was real and "embarrassing.” It was a problem that he had anticipated when, in his bid to make Senators popularly elected, he suggested that the states be divided into larger districts for electing Senators. What was embarrassing was that Madison, his chief ally in proportional senatorial representation, had earlier argued forcefully against the idea of special larger districts. Now Wilson suggested a different method of overcoming the problem that he presented as an alternate, more moderate compromise to the concerns of the small states. He proposed that each state could have one Senator for every “100,000 souls,” every state with less receiving one. Benjamin Franklin then proposed a different compromise that gave each state an

\footnotetext{
236 Ibid., 218-225.

237 Madison, Debates, 222-226. Also see Wood, American Republic, 553-562.
} 
equal number of Senators with a varying number of ballots to cast depending on the subject of the vote. On issues involving state sovereignty, state government or state citizenship, and the appointment of federal officers, each state would have an equal vote. On all other matters, each state would have votes proportional to wealth. No one seconded Franklin's somewhat idealistic solution. Rufus King and James Madison did agreed to support Wilson's compromise if, Madison added, the Senators could be made independent of the states. Otherwise, Madison pointed out, the Senate would just be "another edition of (the Confederation) Congress.” The small-state delegates, however, refused any compromise other than equal representation in the Senate and the stalemate was unbroken.

The frustrated Convention finally decided to form a special committee to decide on a compromise on the Senate. Both Madison and Wilson knew that the committee spelled disaster for them and they protested it, but to no avail. The product of the committee, together with a general fatigue in the Convention over the issue, would be catastrophic to the Madison/Wilson led large-state block, giving the day to the small-state delegates. ${ }^{238}$

On July, 5 the committee delivered its “compromise.” Indeed, historians have come to call it the "great compromise. ${ }^{, 239}$ It proposed proportional representation in the House and equal state representation in the Senate. But, as a sop to the large-state delegates, only the House could originate money bills. Madison claimed that the committee had went beyond its purpose. Nonetheless, the Convention agreed to discuss the committee's proposed compromise and it would dominate the rest of the discussion

\footnotetext{
238 Madison, Debates, 232-237.

239 Rakove, Original Meanings, 57-58.
} 
over the Senate. Over the following days, a tired Convention accepted the clauses of the committee report into the new Constitution over the protests of Wilson and Madison. ${ }^{240}$ Wilson also took a liberal stance on suffrage and office qualifications. Early in the debate over equality of the Senate Rutledge of Virginia and Pierce Butler of South Carolina sided with Sherman's proposed compromise, and they additionally moved that proportional representation in the House be based on "quotas of contribution" because “money was power.” Wilson with Rufus King of New York tried to block the later proposal by calling for a vote to the effect that "the right of suffrage in the first branch of the national Legislature ought not to be according to the rule established in the Articles of Confederation, but according to some equitable ratio of representation.” After Benjamin Franklin threw his weight behind Wilson and Rufus, a vote was made in their favor. ${ }^{241}$ Rutledge and Butler proposed adding “according to quotas of contribution” to the end of “some equitable ratio of representation.” But Wilson and Charles Pinckney of South Carolina postponed a vote to make their own proposal based on the “Act of Congress agreed to by eleven States, for apportioning quotas of revenue on the States.” Following “some equitable ratio of representation” they proposed adding in proportion to the whole number of white and other free Citizens and inhabitants of every age sex and condition including those bound to servitude for a term of years and three fifths of all others persons not comprehended in the foregoing description, except Indians not paying taxes, in each State.

And there should be a Census “every 5-7, or 10 years.” The vote was again made in Wilson's favor, nine states to two, the two dissenters being New Jersey and Delaware. ${ }^{242}$ Later in the debates Governeur Morris of Pennsylvania objected to the method of

\footnotetext{
240 Madison, Debates, 237-298.

241 Ibid., 98-103.
} 
determining representation in the House because he thought that "the people of Pennsylvania will revolt at the idea of being put on a footing with slaves.” And he was against basing representation on numbers of inhabitants in any case, preferring contributions of wealth. Morris raised the specter of future western states. "The Busy haunts of men not the remote wilderness" produced the "proper political Talents" claimed Morris. And "if the Western people get the power into their hands," Morris continued "they will ruin the Atlantic interests." ${ }^{243}$

Madison leapt to diffuse Morris first. As a southerner, Madison claimed to trust the "Northern Majority" and the easterners should trust the westerners for the same reason -- they were all economically connected. Westerners would always want the markets and waterways of the "Atlantic States" for their goods, making eastern interests always relevant. Once more, Madison implied, the Senate could probably be trusted to filter the factional vices of the people. ${ }^{244}$ Wilson admitted that no principled logic underlay the "admission of blacks." Numbers, not property was to be the basis of “computation,” yet chattel was being included in the formula. Or were Blacks being “admitted as Citizens?” No. The purpose of the three-fifths clause was pragmatic -- a compromise. Wilson then asserted that over broad regions the holding of wealth and inhabitants tended to change at the same rate. As an example he compared Philadelphia with the western counties of Pennsylvania. The only difference between the wealth of the two was that "property was more unequally divided...here than there.” Wilson could not reject the idea of representation based on wealth as being wholly onerous because it was too generally accepted as a morally valid method. So, to preserve the more

\footnotetext{
242 Ibid., 103.

243 Ibid., 271.
} 
democratic principle in the House, Wilson skewed wealth and population together. The efforts of Madison and Wilson paid off and their preferred method for computing representation made its way into the finished Constitution. ${ }^{245}$

Wilson made his firmest stand on suffrage based on numbers of inhabitants on July 13, when the issue returned concerning Congress's right to re-estimate proportions. A clause had been added giving Congress to re-estimate based on "wealth and numbers of inhabitants." Randolph proposed striking out "wealth” and Wilson supported him. Wilson compared the fears of some delegates toward growing western influence to the "jealousy" that "misled the policy of Great Britain with regard to America." "The fatal maxims" that molded Britain’s policy "were that the Colonies were growing too fast” and had to be guarded against. "Enmity" and separation was the result.

The majority of people wherever found ought in all questions govern the minority. If the interior of the Country should acquire this majority, it will not only have the right, but will avail themselves of it whether we will or no. Property was (not) the sole or the primary object of Government or society. The cultivation and improvement of the human mind was the most noble object. With respect to this object, as well as other personal rights, numbers were surely the natural and precise measure of Representation.

It was a startlingly democratic statement and connected the purpose of government to civil improvement. Though most surely saw Wilson's position as extreme, in the vote that immediately followed "wealth” was struck out. ${ }^{246}$

Wilson wished to have few restrictions on legislative officeholders, thereby expanding the pool of possible talent from which the people and state legislatures had to choose. He was against age restrictions, property qualifications, financial qualifications

\footnotetext{
244 Ibid., 272-273.

245 Countryman, Americans, 83-84.

246 Madison, Debates, 285-287.
} 
and a restriction to prevent pluralism between federal legislative office and other federal positions. And Wilson, an immigrant, agreed that there ought to be residency requirements but preferred them to be shorter than many others. He wanted the residency requirement for legislators to be three years as opposed to the seven that many others wanted. $^{247}$

Wilson resigned himself to connecting the elector qualifications for federal legislative elections to those in the states for state legislative elections. Any standard set by the Convention, he probably assumed, would run the risk of being more restrictive than state qualifications. Discussions on elector qualifications in the Convention were probably leaning in a conservative direction -- statements by Ellsworth and Mason support such an analysis. On August 7, Governeur Morris suggested that the "right of suffrage" should be restrained to "freeholders.” Wilson disliked "the unnecessary innovation.” It would be too "difficult to form any uniform rule of qualifications for all the States." Additionally, it "would be very hard and disagreeable for the same persons at the same time, to vote for...the State Legislature and to be excluded from a vote for...the National Legislature.” On the heels of Wilson came supporting and telling statements from Ellsworth and Mason. "The right of suffrage was a tender point" Ellsworth said, and "the people will not...subscribe to the National Constitution if it should subject them to be disenfranchised." "Eight or nine States have extended...suffrage beyond the freeholders" Mason added. "What will the people there say, if they should be disenfranchised?” Madison was divided over the idea. Contemporarily, he thought that freeholders would "be the safest depositories of Republican liberty.” However, he thought that land would become more and more

247 Ibid., 376-377, 420-428, 454-456. 
unequally distributed over time. So that, in the future, such restrictions on elector qualifications might give rise to "Aristocracies...built on the ruins of popular forms.” Finally, Morris‘s proposition was voted down. ${ }^{248}$

Discussion over the shape and nature of the new executive, was another area of intense involvement for Wilson. When discussion of the executive opened on June 1, Wilson moved that the executive be a single person. A nervousness poured through the room, so much so that a "considerable pause" occurred in the discussion. To relax his fellow delegates, Wilson explained that he preferred a single executive because it would give the "most energy of dispatch and responsibility to the office." He did not "consider the Prerogatives of the British Monarch as a proper guide. Some of these prerogatives were of a Legislative nature. Among others that of war and peace.” Wilson envisioned the executive to have "only powers...strictly executive (such as) executing the laws, and appointing officers, not appertaining to or appointed by the Legislature.”249

Edmund Randolph objected to "a unity in the Executive" as the "foetus of monarchy." He implied that Wilson was being "governed by the British Government as a prototype." And though he claimed to have respect for the "Excellent fabric" of the British constitution, "the fixt genius of the people of America” Randolph observed, "required a different form of Government.” "Dispatch and responsibility could...be found in three men, as well as one” Randolph asserted, and greater independence from the legislature would be an additional result of a plural executive. Gerry supported the idea of a single executive, but wanted to "annex...a Council...in order to give weight and inspire confidence.” It was between these three ideas of a single, multiple or council

\footnotetext{
248 Ibid., 401-405.

249 Ibid., 45-46.
} 
appended executive, that the arguments over the executive's form would move over the following days. ${ }^{250}$

Wilson answered Randolph that he was "not governed by the British Model," agreeing with Randolph that "the extent of (the Country) was so great, and the manners so republican, that nothing but a great confederated Republic would do for it.” But a "unity in the Executive" would not result in monarchy, rather Wilson claimed, it "would be the best safeguard against tyranny.” When the issue returned three days later Wilson continued in this sentiment when he added, "All know that a single magistrate is not a King.” On June 1, the vote on Wilson’s proposal was postponed. Madison suggested that the powers of the executive be decided on before its form was decided and the Convention agreed. ${ }^{251}$

At the end of the discussions on June 3, Randolph returned to the form of the executive, proposing that three executives exist, each "drawn from different portions of the Country." Pierce Butler of South Carolina contrarily said that he was for "a single magistrate," echoing Wilson's concern for dispatch. The issue was postponed until the next day when Wilson took the floor. Randolph had mentioned that "the temper of the people was adverse to the very semblance of Monarchy" so they would not approve of a single executive. Wilson demanded that it was not true. The people would embrace a single executive just as they had in the states. "All the 13 States tho agreeing in scarce any other instance, agree in placing a single magistrate at the head of the Government," Wilson pointed out. "Vigor" would be the result of a single executive, but three executives would be slowed by internal struggle and even fall victim to divisive

\footnotetext{
${ }^{250}$ Ibid., 46.

251 Ibid., 47, 59.
} 
factionalism. Making their number odd, so that there would hypothetically always be a majority on any issue, was no solution because there would "commonly (be) many sides" to an executive issue rather than just two as in "Courts of Justice.,252

The elder but spry Sherman observed that all of the states also had councils appended to their executives, declaring that he would prefer a council. Hugh Williamson of North Carolina asked Wilson if he "means to annex a Council.” He did not because, according to Wilson, executive councils "oftener serves to cover, than prevent malpractices.” The Convention voted in favor of Wilson's single executive. ${ }^{253}$ Later in the Convention, when an executive council was again considered, Wilson’s reasoning reverberated. George Mason of Virginia proposed an executive council but was defeated. As Wilson’s fellow Pennsylvanian Governeur Morris observed, the idea had already been "considered in the Committee." "It was judged that the President by persuading his Council to concur...would acquire their protection.,254

In discussing the method of selecting the President, beginning on June 1 as well, Wilson took a democratic stand just as he had on the legislature. He was apprehensive to make his proposal "that it might appear chimerical." Wilson was for "election by the people." He pointed to the success of "election of the first magistrate by the people at large" in both New York and Massachusetts. Deriving "not only both the branches of the Legislature from the people, without the intervention of the States but the Executive also" would, Wilson continued, "make them as independent as possible of each other, as well as of the States.” Here Wilson clearly revealed his belief that magisterial corruption would be best guarded against through countervalence, not only between federal

\footnotetext{
252 Ibid., 58-60.

253 Ibid., 59-60.
} 
institutions but the federal and states governments. He also revealed a trust of the common people that was much greater than the trust of most others in the Convention.

Nonetheless, Wilson proved far more willing to compromise on the issue of popular election of the President than he would proportionality in the Senate. Sensing the uneasiness of the Convention with his idea, Wilson contrived the idea of an electoral college. One day after his proposal of popular elections, Wilson proposed a system by which the people would elect electors and the electors would choose the President. But Gerry came out against popular election because such a system would cause "a constant intrigue” for the office and it would give the executive a high legitimacy that would threaten the states. And Hugh Williamson of North Carolina saw no point in having electors since they "would stand in the same relation to (the people) as the State Legislatures” yet electoral colleges would require more effort and money. Apparently, Williamson preferred selection of the President by the state legislatures. Wilson's proposal was defeated. ${ }^{255}$

Yet, Wilson would not let the idea of popular election of the President die so early in the contest. On July 17, Wilson would ally with Governeur Morris to argue the proposition again. It was Morris that breached the issue. He objected to the retained provision in the Virginia Plan that the legislature would appoint the executive. The executive would be a "mere creature of the Legislature." Morris instead proposed popular election in which the people "will never fail to prefer some man of distinguished character, or services." Sherman balked that the people often are "not sufficiently informed" and would be unable to give a majority to any individual because they "will

\footnotetext{
254 Ibid., 600-601.

255 Ibid., 48-51.
} 
vote for some man into their own State.” If such a system would work at all he added, the large states would most likely dominate the Presidency. Wilson rose to support Morris and refute Sherman. He concurred with Morris that appointment of the executive by the legislature would make the executive "too dependent to stand as a mediator between the intrigues...of the Representatives and the general liberties and interests of the people.” The executive was to be a counterbalance to the legislature, with its legitimacy equally drawn from the people. The large states would never form a "cabal" to dominate the executive because the electors would not meet in the same place to decide on their votes. And Wilson suggested a compromise to serve Sherman’s more practical concern for functionality. If the majority could not decide on a single man then it could be thrown to the legislature. Pinckney and Mason sided with Sherman however, and the Convention voted down the still unlikely measure. Luther Martin of Maryland then proposed that electors choose the executive, and that the electors be chosen by the state legislatures. The Convention voted down this proposal but it would soon be resurrected. ${ }^{256}$

Over the next two days the Convention's attitude toward the legislative selection of the executive would change, and Wilson saw a small, short-lived glimmer of hope that the Convention might embrace popular election. In discussions over the term and reeligibility of the President many in the Convention preferred to make the executive reeligible for additional terms, because they valued experience in the executive. But the President's re-eligibility seemed to have made many, who had before been willing to accept appointment by the national legislature, reconsider their views. King returned to Luther Martin’s earlier idea of state selected electors, advancing it once again. Paterson wholly supported King, as would Paterson's partner in the small-state block, Ellsworth.

256 Ibid., 306-309. 
It is clear that by July 19, the leaders of the small-state block had decided that Martin's earlier proposal was in their best interest and were waiting for the issue to be rejoined. ${ }^{257}$

Because many were turning against selection by the national legislature, Wilson thought that "the idea was gaining ground, of an election mediately or immediately by the people.” And Wilson's hope was not uncalled for. Madison himself, the architect of the Virginia Plan that had suggested executive appointment by the national legislature, had turned against the idea of legislative appointment. When it appeared that only two plausible choices for selection of the President existed: electors chosen by the people or electors chosen by the state legislatures, Madison chose the people. He sided with Wilson, saying that "the people at large was in his opinion the fittest (method of appointment) in itself.” But Madison had made his decision too late and the small-state block would win the day. Wilson had initially introduced the idea of an electoral college as a compromise between his democratic preferences and the reticence of his associates. In the hands of Martin and King, however, it became a compromise between continental nationalists and the supporters of continued state power. Madison and Wilson would not be won over by the formula, but enough would be in the Convention to secure its adoption. And yet the issue was still not settled. ${ }^{258}$

At the end of the discussion on July 25 William Houstoun of Georgia and Richard Dobbs Spaight of North Carolina proposed that the selection of the President "be reconsidered.” The Convention agreed and the next day Houstoun, with Spaight seconding, proposed that the electors for choosing the President should be, themselves, chosen by the national legislature. The Convention assented to the proposal but then

\footnotetext{
257 Ibid., 322-328.

258 Ibid., 326-328.
} 
returned again to the re-eligibility of the executive, demonstrating the intimacy of the two issues for the delegates. The connection laid in a general concern for the independence of the executive from the national legislature. The state legislatures, being divided would find it more difficult to join in manipulating the President than the national legislature. The national legislature might hold re-election over the head of the executive thereby controlling him. Making the President ineligible to a second term would give additional protection to the executive. Concerns over inexperience in the executive were assuaged by the idea of longer rather than shorter terms for the Presidency. ${ }^{259}$

Wilson disliked the idea of ineligibility for second terms and longer terms. Reminding the Convention that he still preferred popular election, Wilson alternately proposed that if the national legislature was to select the executive electors, the electors might be chosen randomly by drawing lots. Daniel Carroll of Maryland seconded the motion. Randomness would take the deliberative power to manipulate the executive out of legislator hands. But randomness was itself considered inappropriate by Gerry and King. "Committing too much to chance" would result in the choice of "unworthy men." Also the random lots may all fall to men from one or two states, allowing their electors to dominate the choice. ${ }^{260}$

On July 25, Madison made an exceptional speech outlining the various "mode(s) that has been, or perhaps can be proposed" for Presidential selection. He described the frailties of every mode and again threw his support behind popular election of the electors. "With all its imperfections he liked this best." Ellsworth objected in a short remark that popular election was impractical because a majority would be too difficult to

\footnotetext{
259 Ibid., 355-361.

${ }^{260}$ Ibid., 360-362.
} 
achieve and in any case, the large states would come to dominate the executive. Madison’s plea for popular election was again ignored. ${ }^{261}$ Eventually it was Mason’s proposal that ended this particular row over executive selection. Chosen by the national legislature, the President would serve seven years and be ineligible for a second term. ${ }^{262}$ But the Convention as a whole remained unsatisfied with its progress on the issue of selection as evidenced later in the Convention.

On August 27 Carroll would, with Wilson seconding, motion for popular election of the executive and the motion was easily defeated. ${ }^{263}$ But dissatisfaction was sufficient that a committee of eleven, selected to consider and report on "postponed parts of the Constitution," felt at liberty to entirely alter the method of selecting the executive in their report. The committee returned a report that had the electors selected in each state "as its Legislature may direct," in proportion to the "whole number of Senators and members of the House...to which the State may be entitled.” This alteration set off a new row that lasted three days, but this method of selection found its way into the Constitution along with four-year terms and re-eligibility on September $6{ }^{264}$ The nebulousness of the clause about state selection -- "as its Legislatures may direct” -- left open the possibility of popular elections of electors in the states if the state legislatures decided to allow them. Three allies of Wilson on popular election, Madison, Morris and Carroll, were in the committee of eleven that proposed this wording. Though it is purely conjecture, perhaps they made the clause nebulous deliberately to leave open the possibility of popular Presidential elections directed by the state legislatures.

\footnotetext{
261 Ibid., 363-366.

262 Ibid., 370-372.

263 Ibid., 524.

264 Ibid., 569-593.
} 
When Wilson first made his proposal for a "unity in the executive” he assuaged fears of despotism by saying that he envisioned purely executive powers for the national executive. He would also be against the power of the executive to convene the Senate when the House was not in session. ${ }^{265}$ Nonetheless, the executive powers that Wilson envisioned were quite extensive. Wilson was far more concerned with parliamentary tyranny than any "foetus of monarchy" and saw a powerful President as an ideal counterbalance to the state legislatures and Congress. But concerns of tyranny by most in the Convention ran in the opposite direction and Wilson's ideas were often frustrated. $^{266}$

Wilson supported the power of the President to pardon both before and after convictions as "necessary...to obtain the testimony of accomplices."267 He agreed that the President ought to be impeachable but demanded that Senators also be impeachable and seemed unsure where to place the power of impeachment. ${ }^{268}$ Along with Madison, Wilson vehemently opposed Dickinson's early proposal that the President be impeachable on application by the majority of state legislatures. ${ }^{269}$ Wilson was also against requiring Senatorial consent for Presidential appointments as “blending...the Legislature with the Executive.” The primary point of “unity in the Executive was that officers might be appointed by a single, responsible person.” Legislative meddling in appointments, including the appointment of judges would only weaken the responsibility of the President. ${ }^{270}$

\footnotetext{
265 Ibid., 46-47, 608.

266 Ibid., 464-465.

267 Ibid., 535.

268 Ibid., 332-335.

269 Ibid., 55-56.

270 Ibid., 67-598-601.
} 
Yet, perhaps most startling to a modern observer will be Wilson's desire for the President to have an absolute veto over federal legislation. It was not, however, an unheard of position to take during the period. In crafting the state constitution of Massachusetts, John Adams had unsuccessfully pushed for the governor to have an absolute veto (an executive who would be popularly elected at that.) Men like Wilson and Adams saw an absolute veto as a protection for the executive, preventing the "legislature from swallowing up" the executive. But an absolute veto was not to be accepted by the delegates at the Constitutional Convention any more than it had been earlier in Massachusetts. Madison contrarily "supposed...a proper proportion of each (legislative) branch...required to overrule...the Executive...would answer the same purpose as an absolute veto.” Franklin additionally pointed out that a "negative” could be used to "extort money.",271 Eventually, Wilson supported a 3/4ths requirement for a Congressional override of the Presidential veto as opposed to a 2/3ds requirement to override. $^{272}$ Wilson, however, was also a loyal promoter of Madison’s idea of a joint Judicial-Executive Council vested with the veto power and thought that there should be a powerful federal judiciary in general. ${ }^{273}$

The later point involves the idea of how national or federal the new constitution was to be. Wilson, like Madison, was a continental nationalist who promoted powerful inferior national tribunals with final jurisdiction over state courts in "many cases," particularly admiralty cases. ${ }^{274}$ Most telling though was Wilson’s and Madison’s insistence that Congress have a veto power over the state legislatures. Not only in the

\footnotetext{
271 Madison, Debates, 61-63; Morgan, Inventing the People, 257-260.

272 Madison, Debates, 464-465.

273 Ibid., 72, 79-81, 336, 342-343, 462, 539, 573.

274 Ibid., 72.
} 
interest of comity but in the interest of preserving the new government, Congress had to have some control over state legislation according to Wilson. The danger was greater that the states would "sacrifice...the general interest" than that the "whole will unnecessarily sacrifice a part.,275 Later, Wilson compared the new government to a "wide arch" and Congressional veto of state laws was "the keystone.” Anticipating judicial review of the constitutionality of laws Wilson held that federal judges might be able to determine the unconstitutionality of a state law, but that was not good enough. "It will be better to prevent the passage of an improper law, than to declare it void when passed. ${ }^{\text {276 }}$ Congressional veto of state laws was not agreed to of course, the supremacy clause was meant to substitute it, and over the last two hundred years the acceptance of judicial review has given that clause some force. ${ }^{277}$

As the Constitutional Convention neared its end the thoughts of the delegates turned to ratification. Wilson wanted the proposed Constitution to bypass Congress and go directly to the states for ratification where only a bare majority of seven would allow it to go into effect. Madison worried that even if the ratification of nine states was required to affect the new government, the population of those states might consist of less than a majority of the whole American people. The result would be a constitution forced onto the majority by the minority. Dickinson queried whether it could be considered appropriate to by-pass Congress since the present “Confederacy” rested on Congress. Wilson answered the uncertainty of both Madison and Dickinson on August 30. "The States only which ratify can be bound" Wilson suggested to Madison, those that did not

\footnotetext{
275 Ibid., 88-91.

276 Ibid., 518.

${ }^{277}$ United States, “United States Constitution, Article VI” in American Charters, Volume I, 27. Also see Countryman, Americans, 73-85.
} 
ratify would not have the Constitution thrust upon them. Looking to Dickinson, Wilson boldly asserted that "a House on fire must be extinguished, without a scrupulous regard to ordinary rights." "We must," he continued "go to the original powers of Society."

The next day Madison proposed that "seven or more States entitled to thirty three members at least in the House of Representatives” be required to put the Constitution into effect. "The people were" Madison remarked, "the fountain of all power, and by resorting to them, all difficulties were got over." "They could alter constitutions as they pleased," ruminated Madison, and "it was a principle in the Bills of rights, that first principles might be resorted to.” Wilson appreciated Madison’s popular logic, acknowledging constitutions as instruments of the people. He seconded. ${ }^{278}$ Such exigencies were made unnecessary however, because the Convention adopted Wilson's doctrine that states not ratifying should not be forcibly compelled into the Union. Though the Convention appreciated Wilson's observation on non-ratifying states, they rejected his attempt to by-pass Congress. Congress would have to assent to the new Constitution before it went to the states where it would require ratification in nine states to make it active. States not ratifying the Constitution would not be compelled to live under it, but would be allowed to join afterward. ${ }^{279}$

The final product of the Convention was not as national or democratic as Wilson had wanted, but it had enough of these attributes for Wilson to later argue the democratic nationalism of the new Constitution. Indeed, Wilson would be a key proponent in its ratification. Once the proposed Constitution had been issued by Congress to the states for ratification, Wilson and Robert Morris easily secured preparations for a ratification

\footnotetext{
278 Madison, Debates, 561-565, 613.

${ }^{279}$ Madison, Debates, 613, 626; United States, “United States Constitution, Article VII” in $\underline{\text { American }}$
} 
convention in the Republican dominated Pennsylvania Assembly. As the federalist and anti-federalist ranks formed in Pennsylvania, it became quickly apparent that the new fissures followed the old factional lines very closely. Dedicated Constitutionalists tended to become anti-federalists while Republicans became federalists, supporting the new continental charter. ${ }^{280}$

\section{CHAPTER VI \\ WILSON AND THE TWO NEW CONSTITUTIONS}

In the ratification controversy that followed the Philadelphia convention, Wilson proved to be a dogged Federalist partisan. Wilson's dedication to popular

Charters, Volume 1, 27.

280 Smith, Wilson, 256-270. 
instrumentalism and continental nationalism was interwoven throughout his partisan polemics. He put forward his theoretical principle of civil revolution, embodied, he claimed, in the amendment process of the proposed 1787 federal Constitution. And his faith in the People to rule themselves carried through to the new Pennsylvania Constitution of 1790 .

The federal Constitution, with its bicameralism, and single executive selected by electors, was much closer to what Republicans wanted for Pennsylvania than what the Constitutionalists cherished in their 1776 Constitution. Adoption of the federal Constitution would be a virtual indictment of the Constitutionalists, setting the foundation for the destruction of the Pennsylvania Constitution and the permanent pre-eminence of the Republicans. The Constitutionalists knew their danger, and their fears proved well founded. The adoption of the federal Constitution was their death knell; resistance to it was their last meaningful effort to resist. And even this last effort was doomed to failure. The Constitutionalists became marginalized by 1787, developing into a faction of western farmers that consistently alienated Philadelphians. Just as the Republicans dominated the Assembly, so would they dominate the Pennsylvania ratifying convention. The westerners only slender hope was to use the specter of tyranny to win over fence-setters among the easterners while tiring the federalist leadership with repetitive arguments, and that is exactly what they attempted. ${ }^{281}$ So Wilson's defiance of the anti-federalists inside and outside the convention was of secondary importance.

The greatest importance of Wilson's efforts came from the contents of his orations. The masterfulness of Wilson's reasoning and delivery amazed his observers and received the attention and applause of federalists in other states who often co-opted 
his arguments. ${ }^{282}$

On October 6, Wilson was elected to attend the Pennsylvania ratifying convention. He made his acceptance speech before a large group in front of the Pennsylvania State House. Anti-federalist polemics had already become diffused throughout Pennsylvania and, in what posterity commonly calls the "State House Yard Speech," Wilson used his forum to refute some of the "insidious attempts" of the antifederalists to "clandestinely and industriously...pervert and destroy the new plan.” The speech was telling of Wilson's thought following the Constitutional Convention, and predicated the arguments Wilson used against the anti-federalists in the ratification convention.

The anti-federalists charged that the new Constitution was a tool of despotism, evidenced by the lack of a bill of rights. Historian Edmund S. Morgan has said that this argument was one of the most convincing made against the Constitution. According to Morgan, the majority of federalists denied the need for a bill of rights on the basis that the government of the new Constitution would be purely republican, resting on the principle of popular sovereignty. The people had no need to limit their own power. Pigeonholing James Wilson into this group opinion, Morgan claimed that Wilson thought that the popular power of amendment was a sufficient replacement for any bill of rights. Indeed, the bills of rights that existed in the earlier state republics were hypothetically antiquated tools of mixed constitutionalism, relevant when the Commons needed protection from the monarch. Morgan speculated that the presence of bills of rights in those first, purely republican state constitutions "recognized the fictional quality of popular sovereignty."

\footnotetext{
281 Ibid., 282, 296-299.

282 Smith, Wilson, 263-270, 279-280; Wood, American Republic, 539-541.
} 
Yet, Morgan’s interpretation of Wilson's thought is simply wrong. ${ }^{283}$ Wilson never argued that popular sovereignty and the popular amendment process replaced bills of rights. In fact, Wilson was more than happy to acknowledge that in some instances bills of rights were very necessary under republican government. The key determinant for Wilson was precisely how the functional powers that the people delegated were presumed to be transferred.

Answering for a lack of a bill of rights, Wilson stated that when the people established their state governments they gave their representatives every legislative power not "in explicit terms reserved" to the people. So in the states bills of rights were necessary to limit the power of the government. In other words, the people delegated a whole species of power with nebulous parameters and a bill of rights helped to define the extent of government powers through negative assertions. "But in delegating foederal powers” Wilson contradistinguished "another criterion was necessarily introduced,” indeed, an opposite criterion. It was “positive grant,” not “tacit implication” that legitimized federal power. So that "everything that is not given” to the federal government "is reserved" to the people so that a bill of rights was not necessary. Only specific and itemized functional powers were going to be transferred to the new government upon ratification, not an entire species of governmental powers.

Wilson used a popular concern for "Liberty of the Press" as his example. It could not be violated by the federal government because the federal government had not been given any power to regulate the press. In fact, a bill of rights would more likely undermine popular rights in the long run since "a formal declaration upon the subject" of the press or any other right "might (be) construed to imply that some degree of power

283 Morgan, Inventing the People, 282-285. 
was given, since we undertook to define its extent.” Wilson rejected the doctrine of implied powers that he had helped pioneer under the Articles, because of how power was to be delegated to the new government. ${ }^{284}$

Wilson continued to engage complaints about the lack of a jury guarantee in civil trials and the probability of a standing army under the government. On these issues Wilson was wholly dismissive, contending that the guarantee of juries in criminal cases was sufficient to secure liberty and that standing armies were necessary for national security. $^{285}$

Interestingly, anti-federalist polemics forced Wilson to defend the Senate. It was an institution that he was not fond of himself because he thought it threatened interference with majoritarian will by an arbitrary popular minority via the small states. ${ }^{286}$ Anti-federalists had predicted the development of "a baneful aristocracy in the foederal senate.” Wilson considered the idea completely unreasonable. The Senate had "two characters, the one legislative and the other executive.” As legislators, Senators could do nothing without the House of Representatives. As executors, Senators could do nothing without the assent of the President. "I do not know of any act which the senate can of itself perform” Wilson continued, and so no chance of senatorial despotism existed. He admitted that the Senate was the product of compromise "between contending interests," but that the fact "ought rather to command a generous applause, than to excite jealousy

\footnotetext{
284 James Wilson, “An Address to a Mass Meeting at the State House in Philadelphia, 6th October, 1787" in Political Essays ed. Adams, 153-155. Also see Alexander Hamilton, "The Lack of a Bill of Rights" or "Federalist, Number 84" in Federalist, 534-535. Hamilton later borrows Wilson's argument for the nonnecessity and dangerousness of a Bill of Rights for the federal Constitution.

${ }^{285}$ Wilson, “An Address to a Mass Meeting” in Political Essays, 155-156.

${ }^{286}$ Madison, Debates, 220-222.
} 
and reproach.”287

The anti-federalist accusation, Wilson argued, that the new Constitution would make the state governments into irrelevancies was erroneous. He pointed out that without the states the federal government could not function. The President and the Senate could not be selected without the state legislatures -- neither could Representatives to the federal House because their qualifications were attached to the state legislatures.

“The power of direct taxation” should not be feared either, Wilson told the crowd. It would rarely be used because imposts would prove sufficient to fund the government most of the time. Direct taxation was necessary in cases of emergency and may also raise money to be used, he observed, to relieve the immense public debt that Pennsylvania presently suffered under. And whether money was raised by impost or direct taxation “no...reason to apprehend oppression” existed because the federal government would only have such authority based on “universal assent” -- through popular representation, was Wilson‘s implication. ${ }^{288}$

Wilson finished by accusing the anti-federalist of being interested partisans, dedicated to preserving their "place of profit under the present establishment.” Boldly, he admitted that he was "not a blind admirer of this plan of government, and that there are some parts of it, which if my wish had prevailed, would have certainly been altered.” Nonetheless, Wilson proclaimed, the proposed Constitution was, over all, a brilliant achievement. He concluded,

When I reflect how widely men differ in their opinions, and that every man has an equal pretension to assert his own, I am satisfied that any thing nearer to perfection could not have been accomplished. If there are errors, it should be remembered that the seeds of reformation are sown

${ }^{287}$ Wilson, “An Address to a Mass Meeting” in Political Essays ed. Adams, 156-157.

288 Ibid., 158-159. 
in the work itself. Regarding it then... with a candid and disinterested mind, I am bold to assert, that it is the best form of government which has ever been offered to the world. ${ }^{289}$

Wilson was ready for the ratification convention -- and he needed to be. He was a renowned orator and lawyer, and the only member of the Constitutional Convention to attend the Pennsylvania ratifying convention, and so carried the greatest responsibility on his shoulders. But before ratification was achieved, Wilson would be worn to a frazzle answering the constant and repetitive attacks of the western anti-federalists Robert Whitehill, William Findley and John Smilie. ${ }^{290}$

The federalist Thomas McKean opened the main business of the ratification convention on November 24 proposing that, though each clause should be discussed, the whole Constitution was to be accepted or rejected and not just parts of it. Wilson followed with an extensive explanatory speech, infused with historical observations, to promote the proposed Constitution as a positive good. The speech touched on many elements of Wilson's developed political thought. He began where he left off in his State House Yard Speech describing the political and conceptual difficulties that the Constitutional Convention faced and according to Wilson, overcame using "general principles.”

Establishing government "for a single city...require(d) the strongest genius," much less one for vast region that will hold "yet unformed, myriads of the human race” set to expand to the west over "regions hitherto uncultivated." Indeed, the delegates at the Constitutional Convention had understood there to be implications in their work for

\footnotetext{
289 Ibid., 159-160.

290 "The Debate in the Convention" in Pennsylvania and the Federal Convention, 1787-1788, Vol. I, John Bach Master and Frederick D. Stone ed. (New York: Da Capo Press, 1970), 210-431; Smith, Wilson, 262269.
} 
all humanity. "The great struggle for liberty in this country, if it is unsuccessful" according to Wilson, "will probably be the last one which she will have for her existence...in any part of the globe.” America was to be a model to the world for liberty and the kind of political activity and principles that would support it. So the responsibility of the Constitutional Convention had been great and "the difficulty of the business was equal to its magnitude.” Both the difficulty and magnitude had "astonished” Wilson. And he thought it was amazing that a diverse group of men from diverse regions of the continent were able to compromise and reach an acceptable finished product. By implication the responsibility belonged to all Americans and certainly those considering ratification of the new Constitution. It was a heavy message designed to produce a serious atmosphere in the ratifying convention, bent in favor of accepting the new government. ${ }^{291}$

Numerous disagreements arose among the Founders, but two general obstacles most troubled the Convention according to Wilson. The first was that the "sense of independence and freedom” among the people made them difficult to govern, making a long-lasting, centralized continental government implausible. Second, contemporary political theory contradicted the American effort to erect a government that was both continental and wholly republican. Appended to this second concern was the more practical concern of how national or how federal the continental government was to be -a concern exacerbated by a common understanding of the real differences between the people of the various states. ${ }^{292}$

On the first issue, Wilson confided that the "high spirited" nature of the people

291 James Wilson, “Commentaries on the Constitution, 1787” in Political Essays ed. Adams, 163-164, 176, 179. 
had never worried him as it had others. Yes, they were high spirited but they also “possess(ed) sound sense,” he declared. "They would,” Wilson continued "be...pleased with that system of government, which would best promote their freedom and happiness.” As a federalist, Wilson believed that the plan for such a government was before the ratifying convention. ${ }^{293}$ He could discern no reason for the people to reject the new constitution because it would solidly rest on their sovereign authority.

Wilson concurred with other early modern writers in their variation on Aristotelian categories of government, a concept that had come to Americans by various other sources not least Montesquieu. There were three "simple species of government -monarchy, aristocracy (and) a republik or democracy."294 Wilson does not make the rigid distinction between a republic and a democracy the way Madison later would in $\underline{\text { The }}$ Federalist. ${ }^{295}$ The new constitution with its countervailing governmental institutions, efficient variations in function, and federalism (pointedly NOT mixed government) would allow the new government to have the positive attributes of all these forms of government without their requisite failings. Yet, "in its principle” the new government would still be "purely democratical.” "The streams of power” Wilson happily continued “(ran) in different directions, in different dimensions, and at different heights...but...they all originally flow from THE PEOPLE.”296 Wilson would go even further and describe what later historians have referred to as Wilson‘s "revolution principle."297

\footnotetext{
292 Ibid., 165-166, 174.

293 Ibid., 165.

294 Pocock, Machiavellian Moment, 272-330.

${ }^{295}$ Madison, “Representative Republics and Direct Democracies” or "Federalist, Number 14” in Federalist, 150-155.

${ }^{296}$ Pocock, Machiavellian Moment, 180-181.

${ }^{297}$ Pascal, Political Ideas, 29-47. Also see Dennison, "Revolution Principle” in The Review of Politics, 39 (1977).
} 
"Writers on different governments will give different answers" to where sovereignty resides, Wilson admitted. Blackstone placed it in British Parliament. Wilson no longer refuted Blackstone but simply observed that in American governments "the supreme, absolute, and uncontrollable power remains in the people." Their "constitutions were superior to (their) legislatures; so the people are superior to (their) constitutions.” “The people may change the constitutions," Wilson deduced "whenever and however they pleased.” Once more, the Revolutionary generation had proven that political revolutions could result in progress and that they were not inherently evil. ${ }^{298}$

Contemporary, un-transferrable popular sovereignty was to be the American "panacea of politicks." Bravely Wilson bellowed over his audience, some of whom must have been astounded at the "aristocrat's" doctrine, "there can be no disorder in the community but may here receive a radical cure.” The one exception was a corruption in the people at large themselves, for which "there is no remedy -- from their power...there is no appeal.” But Wilson did not think the people corrupt. And in the new constitution an amendment process was included that could fully realize this new American understanding through a peaceful and lawful process. No good reason existed for the “high spirited” people to rebel en masse against the new government. ${ }^{299}$

The second problem of the expansive republic was one that arose from a broad acceptance among the founders of the political thought of Montesqueiu. They considered the French philosoph a high political authority. His writing was well known by Wilson and most of his colleagues. Montesqueiu thought that republics were most often destroyed by internal factionalism arising from differences among members of the

\footnotetext{
${ }^{298}$ Wilson, “Commentaries” in Political Essays, 178-180.

${ }^{299}$ Wilson, “Commentaries” in Political Essays, 180.
} 
republic. Great diversity in culture or regional environment, and therefore economy, only exacerbated differences of interest and the propensity for factionalism. On the other hand, greater homogeny relaxed differences and the propensity for factional strife. Because diversity only increased as the size of a state increased republics only survived for prolonged periods when they were small; factional strife doomed large republics. So, in the interest of stability, larger nations could not be wholly republican if at all republican. The larger or more diverse the state, the greater necessity for concentrated power separate from the broader community that might control violent or stagnating divisions in the political society. ${ }^{300}$ As Wilson described Montesquieu’s thinking, "small states (are) to be governed as a republick; middling ones, (by) a monarch; and...large empires...by a despotic prince. ${ }^{\text {„301 }}$ But the founders wanted to establish a pure republic over a vast continent without the appended prediction of inevitable doom.

James Madison struck at the fundamental assumptions of Montesquieu both in the Constitutional Convention and later as one of three that took on the synonym "Publius." According to Madison, factionalism was inevitable in even the smallest republics. And the fewer the factions, he argued, the more likely one faction would come to dominate tyrannically over the opposing factions. Perhaps drawing from a common American assumption in the states that smaller legislative bodies were inherently more conservative, Madison hypothesized that the more factions there were in relation to the representatives of government the better. Because if there was a plethora of factional interests no single faction would be able to long dominate a representative or governmental policy. Therefore the deleterious effect of factionalism on republics could

\footnotetext{
${ }^{300}$ Greene, Intellectual Heritage, 43-44.

${ }^{301}$ Wilson, "Commentaries” in Political Essays, 166.
} 
be remedied by "enlarge(ing) the sphere" of the participatory community. Inspired by James Harrington’s and David Hume’s fictive models of ideal extended republics, Madison proposed that a larger republic was preferable to a small one because the larger population would magnify the diversity of interests in the state and therefore potential factions. $^{302}$

Wilson, on the other hand, denied Montesquieu's prediction of doom obliquely, using the concept of "Federal Liberty," a concept imbedded in the proposed constitution, that if applied would be a unique blessing for the United States. He did not embrace Madison’s theory that “enlarged spheres” would counteract domineering factionalism -filtering popular passions in the legislative process.

Montesquieu had suggested that the happiest extensive territorial state was one of many small republics confederated under a monarchy. Such a state might balance republican liberty with monarchial dispatch and the defensive capabilities of a larger population. The philosoph’s ideal model was really a reconfigured version of the British concept of mixed government. ${ }^{303}$ Wilson thought that the new government combined the best attributes of monarchy (and aristocracy) with purely republican forms. This new republicanism would sit in the place of Montesquieu's monarch. Once more, the federal nature of the system itself promoted the security and even progress of American liberty. “Civil government," Wilson reminded his listeners "was necessary to the perfection of society." "Civil liberty” was formed when individuals gave up "part of (their) natural liberty" to the community. The proper goal of civil society was to better secure and

\footnotetext{
302 Madison, Debates, 75-77; Madison, “The Size and Variety of the Union as a Check on Faction” or "Federalist Number 10" in The Federalist, Alexander Hamilton, James Madison and John Jay, ed. Benjamin F. Wright (New York: MetroBooks, 1961), 129-136; Wood, American Republic, 503-504; Ketchum, Madison, 240-242; Morgan, Inventing the People, 268-269.
} 
perfect the liberty that was retained. As Wilson put it, “The liberty of every member is increased by this introduction, for each gains more by the limitation of the freedom of every other member, than he loses by the limitation of his own.” Wilson then extrapolated this broadly accepted idea into an understanding of the proposed federal system. The states, by giving up their sovereignty and certain liberties to the federal government, would have the liberties they retained better secured and advanced upon. The happy effect would be felt by the citizens of the states. Perhaps inspired by Wilson, Alexander Hamilton later used a similar argument during the ratification contest in New York. $^{304}$

Following Wilson’s speech the western and eastern factions began a day-long argument over procedure. ${ }^{305}$ Once the real debates got underway, the argumentation between Wilson and the anti-federalists in the convention stayed very much within the confines of the wrangle leading up to the convention. Most interesting were Wilson's comments on the rejection of state sovereignty and the non-contractual nature of the federal constitution. Wilson emphatically answered anti-federalist objections to the activity of the earlier Constitutional Convention and their abandonment of state sovereignty on December 11.

William Findley had mentioned that the delegates, he thought, assumed themselves to be forming a new contract for the American states. Wilson rebutted,

I cannot answer for what every member thought; but I believe it cannot be said that they thought they were making a contract,

303 Bailyn, Faces of Revolution, 253-257.

${ }^{304}$ Wilson, "Commentaries” in Political Essays, 172, 174-176; Alexander Hamilton, "Union as a Barrier to Faction and Insurrection" or "Federalist Number 9" in Federalist, 124-129.

305 "The Debates in the Convention" in Pennsylvania and the Federal Constitution, ed. McMaster and Stone, 234-248. 
because I cannot discover the least trace of compact in the system. ${ }^{306}$

It took at least two parties in the forming of a contract, Wilson remonstrated. But in the legitimization of the constitution only one party acted -- the People. "I am,” Wilson sarcastically observed "unable to conceive who the parties could be.” Wilson plied his case to the situation of ratification.

This (new government) is not...founded upon a compact; it is founded upon the power of the people. From...their ratification alone it is to take its constitutional authenticity; without that it is no more than tabula rasa.

Wilson rejected the idea that the state governments were, or even could be sovereign and concurrently any idea that a national constitution could be thought of as a treaty between them. ${ }^{307}$

The twenty-three day long, federalist-dominated Pennsylvania ratification convention was the first to meet and the second to ratify the constitution, following Delaware. ${ }^{308}$ Three years after ratification and the official institution of the new form of government, the Constitutionalist prediction of their own final defeat came true. In 1790, Pennsylvania Republicans succeeded in calling for a state constitutional convention. Wilson dominated the constitution-making process, forwarding a product that was similar to the federal constitution and yet exceedingly Wilsonian. ${ }^{309}$

The 1790 Constitution had a single executive, a bicameral legislature and a judiciary that served during good behavior. The governor held a limited veto of legislation as in the federal Constitution but would appoint judges without the

\footnotetext{
306 "The Debates in the Convention" in Pennsylvania and the Federal Constitution, ed. McMaster and Stone, 383.

${ }^{307}$ Ibid., 384-386.

308 "The Debates in the Convention” in Pennsylvania and the Federal Constitution, Volume II, ed. McMaster and Stone, 380; Smith, Wilson, 284.
} 
interference of the legislature. Popular elections selected both the governor and the legislators of both legislative houses. Conservatives from Wilson's own federalist ranks, including McKean, had objected to the immediate election of Senators but Wilson had backed them down. Wilson also secured liberal parameters for suffrage. ${ }^{310}$ A fellow delegate remarked that "with a few exceptions" Wilson was "on the democratic or antifederal side of the house. ${ }^{311}$ His erstwhile federalist allies must have been mortified.

Because general species of power were delegated to the Legislature and Governor rather than specific enumerated powers, a bill of rights (perhaps more correctly understood as points of governmental limitation) was necessary. It was a point that no one seemed to disagree on. Article IX of the Pennsylvania Constitution involved twentysix sections limiting the powers of the Legislature and Governor in very specific ways. ${ }^{312}$

The state constitutional convention had their proposed constitution printed and distributed to the Pennsylvanian public. After a week of receiving feedback they reconvened and, assuming themselves capable of acting as a popular ratifying convention, ratified the new constitution in the name of the People. ${ }^{313}$

Wilson's arguments during the constitutional crisis of the 1780s show him to be a continental nationalist, who trusted the People at large to choose capable leaders through direct election. Danger in republican systems came primarily, for Wilson, through magisterial corruption. Even the most capable men could be corrupted by power. Wilson's republican remedy was more adequate checks and balances in government, and

\footnotetext{
309 Smith, Wilson, 298-304.

310 Smith, Wilson, 300-304; Pennsylvania, “Constitution of Pennsylvania--1790” in American Charters, 3092-3099.

311 Alexander Graydon quoted in Wilson, Smith, 303.

312 Pennsylvania, “Constitution of Pennsylvania--1790” in American Charters, 3099-3101.

${ }^{313}$ Commented on by Thorpe in American Charters, ed. Thorpe, 3092; Smith, Wilson, 304.
} 
a full realization of popular sovereignty that included a democratic spirit in governance and instrumental constitutionalism. Wilson could not accept the contra-popular rationalizations of Madison's remedy, such as larger constituencies filtering out popular passions, because within the context of the legislative process the immediate popular will was to be wholly trusted. But like Madison, Wilson envisioned a continental republic and rejected the idea of the 1787 federal constitution as a Lockean contract in favor of a view of the constitution as an instrument of the People at large. 


\section{CHAPTER VII}

\section{THE PROGRESSIVE CONSTITUTIONAL DOCTRINE}

During his 1790/1791 law lectures at the University of Pennsylvania, Wilson elucidated his view of popular sovereignty, describing its origins, essential nature and limitations. He also connected his understanding of popular sovereignty and constitutional instrumentality to a larger concept of "civil society" whose progress was to be preserved and facilitated by government. Wilson's overall vision of society and ultimately constitutional government was revealed to be progressive.

Before engaging some of Wilson's more in-depth conceptual arguments, it will be productive to first return to exactly what Wilson thought progress was or might be in the late eighteenth century United States. Even before his lectures, Wilson’s business activities are telling in regard to his view of socio-economic development.

As discussed before, Wilson was a supporter of banking and governments chartering banks. But the late 1780s brought a hypothetical embarrassment for Wilson that, because of his professional trajectory, he avoided. In his arguments during the ratification controversy, Wilson rejected the idea of implied powers for the 1787 federal Constitution. Unlike the state constitutions or the Articles of Confederation, the 1787 Constitution did not grant all legislative powers to Congress, rather the instrument 
granted only very specific legislative powers. So, according to Wilson, a bill of rights was not necessary under the 1787 federal Constitution, unlike under the state constitutions that did grant very general categories of governmental power.

Because of his arguments during ratification it would have been difficult for Wilson to resurrect his doctrine of implied powers that he employed under the Articles to justify the Bank of North America, to argue the constitutionality of a federally chartered bank under the 1787 Constitution. No clause in the enumerated powers of Congress gave Congress the power to charter banks. But re-working Wilson's earlier doctrine of implied powers is exactly what Alexander Hamilton did in 1791 when he argued for a Bank of the United States under the "necessary and proper” clause of the new federal constitution.

Congress had let the charter of the Bank of North America terminate in 1786, though it continued under a Pennsylvania state charter (it had been re-chartered by a Republican dominated Pennsylvania Assembly.) In 1790 Hamilton proposed a national bank that was rigorously resisted by James Madison, who argued that Hamilton’s notion of implied powers were inapplicable to the federal Constitution. Congress sided with Hamilton, however, as did President George Washington contrary to the advise of Thomas Jefferson. ${ }^{314}$

Wilson never left a public record of what he thought about the contention between his old Federalist allies. He would not return to Congress after 1787, but re-entered the federal government as a founding member of the Supreme Court in 1790. He was, perhaps blissfully, absent for the revival of the bank controversy. What can be said is that Wilson supported the general idea of banks being chartered by governments and he 
continued to take loans from the Bank of North America to fuel his land speculations.

It was in the arena of western lands, immigration and foreign investment that Wilson saw the best resources for American social and economic development in his own time. Wilson became a lavish land speculator following American Independence to the point of being addicted to the business. As early as 1790 many of his close associates began to worry about Wilson's mounting debt and his debt problems hindered his judicial career. Wilson had hoped to be appointed Chief Justice of the Supreme Court and he wrote to President Washington offering his services. Eventually, Wilson was only appointed Associate Justice to the chagrinned surprise of some of his friends. Whispered rumors of Wilson’s precarious financial situation had influenced Washington‘s decision. The lands that Wilson bought and the mills that he built on many of them simply were not returning the profits that he had anticipated, and yet he continued to take out loans to buy new properties. ${ }^{315}$

His obsession with land speculation says much about Wilson. On the surface it may suggest an impulsive personality as a whole, but such a conclusion would not be supported when looking at other areas of Wilson's life history. Like most Americans to this very day, for Wilson no better enterprise existed than one that would make him rich and advance the prosperity of the whole society at the same time. The development of western lands offered such a dual opportunity to Wilson's generation. It was only a matter of time until the immigrants poured across the sea in even greater numbers to enjoy the enlightened freedoms of federal America. As Wilson observed, Americans had “formed and now enjoy a Constitution excellent in its organization, and still more

\footnotetext{
314 Risjord, Jefferson's America, 1760-1815, 149, 214.

315 Smith, Wilson, 304-307.
} 
excellent in its...Principles.” The oppressed of Europe would clamor for American liberty and the promised wealth of American lands. ${ }^{316}$

Among Wilson's notes may be found a proposal made to an unknown recipient titled "Prospectus of an Association for the Promotion of Lands for Settlement.” It is an ambitious plan to form a private association for the settlement of western lands by European immigrants, using excess European capital. This Association would seek out Europeans wishing to immigrate. Given land and services in the form of loans, immigrants were to slowly repay the Association in either capital or surplus crops over a period of eight years. Transported across the ocean on reliable, Associate-approved ships, the new immigrants might take carriages and wagons provided by the Association to their new lands in the west. The plan allotted each family as much as two to three hundred acres apiece. Necessary buildings and works for drainage were to be built by the Association before the immigrants arrived, as well as a subsistence garden planted to insure their survival through their first years. The immigrants also had the option of hiring on loan, from the Association, a guide to teach them necessary farming skills. Unfortunately for hundreds of thousands of immigrants over the following decades, Wilson’s highly ambitious but humane plan never became more than a hazily envisioned dream. $^{317}$

Wilson's debts mounted over the 1790s until the bottom fell out of the land market in 1798. This recession financially ruined the Associate Supreme Court Justice. Wilson fled from his creditors to South Carolina, where he died penniless from malaria. His young second wife Hannah, whom Wilson had married in 1793, must have been

\footnotetext{
316 James Wilson, The Papers of James Wilson in the archives of the Pennsylvania Historical Society.

${ }^{317}$ Smith, Wilson, 157-168; Wilson, Papers of Wilson in the archives of the Pennsylvania Historical
} 
devastated. $^{318}$

Yet, Wilson’s ideas about progress were not confined to economics. And even economic progress itself was intimately connected, in Wilson's mind, to the political health and progress of society. In the fearful atmosphere of the later Confederation period, Wilson jotted notes in favor of centralized regulation of commerce that, combined with the natural "Richness of ... Soil, Numbers, and values of ... Productions" in the United States, would make America into an economic power-house. Though politically lacking in regard to central regulation, the United States was otherwise already sufficient in political acumen to seize the economic prosperity that was in her reach. Wilson complemented the people of the states, saying that "the Genius of their Governments is favorable to Trade, because it is favorable to Equality and Industry, the ONLY pillars on which Trade can be supported.” By “Equality,” Wilson probably meant equitable laws and political practices. After 1787, when the problem of lax central authority was supposedly solved, Wilson assumed that the perfected political situation of America, and its communication across the Atlantic, would be part of the impetus for a new confluence of freedom and immigrants. ${ }^{319}$

Nonetheless, in Wilson's speeches and later lectures at the University of Pennsylvania, "progress” generally had more to do with political, intellectual and moral advancement than economic development. In a celebratory speech, glorifying the 1787 federal Constitution following a federalist parade to celebrate the first anniversary of the Constitution's ratification, Wilson spoke of purely moral and political advancement. Wilson happily proclaimed that,

${ }^{318}$ Smith, Wilson, 366-367, 376-388. 
A progressive State is necessary to the Happiness and Perfection of Man. Whatever attainments may be already possessed, attainments still higher ought to be pursued. It is our Duty, therefore, to press forward, and to make increasing Advances in every Thing that can support, improve, refine and embellish Society. ${ }^{320}$

The Constitution and its underlying principles Wilson defined as advancements. Specifically, Americans had discovered a moral imperative that "all the derivative Movements in Government must spring from the original Movements of the People at large.” This placed the initial duty and right of progress squarely in the hands of the people at large. Government was only a facilitator -- a helpmate.

One of the most important ways that the people exercised their duty was in voting -- their "first connection in politics." (Another important democratic duty, in Wilson's opinion, was the duty of jurors to represent the People in the legal process.) Deliberation and voting itself therefore must be understood, according to Wilson, as a moral obligation comparable to that of a soldier's duty to defend his country. In a portion edited out by Wilson, he wrote of the celebration of the Constitution itself being an advancement because it compelled contemplation of fundamental political principles. He ended his speech prayerfully. "The Commencement of our Government has been supremely glorious," Wilson proclaimed. "Let our progress in any Excellence be proportionally great." ${ }^{321}$ Wilson's progressive line of thought would be continued in his law lectures. Wilson's reputation throughout the states for genius in law had long proceeded his appointment to the embryonic Supreme Court. As early as 1782, Wilson’s reputation was broadly enough known for the Virginian, General Washington, to request Wilson's

\footnotetext{
319 Ibid., 164-167.

320 James Wilson, “Address on Occasion of the Public Demonstration on the Adoption of the Constitution of the United States" in Papers of Wilson in the archives of The Pennsylvania Historical Society.

${ }^{321}$ Wilson, "Adoption of the Constitution" in Papers of Wilson in the archives of The Pennsylvania
} 
services in mentoring his nephew, Bushrod Washington, in the legal profession. Ironically, it would be Bushrod who took Wilson's empty seat on the Supreme Court following Wilson's ignominious and untimely death. ${ }^{322}$

In 1790 the Board of Trustees of the College of Philadelphia, that included Wilson, approved the addition of law lectures to the school's curriculum. And Wilson, only recently appointed to the Supreme Court, was the most sensible choice to give the lectures. Wilson commenced organizing his law lectures in the winter of the same year. Considering the rapidity of their construction Wilson's lectures are succinct and well organized, pooling and rationalizing together most of the conceptual elements important to Wilson and his generation.

Other than A Defense of the Constitutions of the United States by John Adams, Wilson's lectures in law are the closest the Revolutionary generation ever came to producing an in-depth philosophical treatise involving the principles of their revolutionary struggles. And the law lectures may be more representative of political thought in the United States at the time than A Defense, a treatise that was not wellreceived. ${ }^{323}$ Wilson's lectures both plumbed the depths of epistemology while hugging the borders of theology and pragmatism. In them, Wilson propounded precepts of human intellect, sociability and the human relationship to natural and divine law. These fundamental precepts were, in turn, used to construct a theory of society, government and political sovereignty. The middle-aged professor of law then took care to connect these appropriate principles to the new political and legal reality of post-Confederation America. It is not implausible that Wilson might have become the Revolutionary 
generations most profound political theorist had he not drowned in debt and died early at the age of $56 .^{324}$

Of course, Wilson did not organize his lectures as a political treatise because they were to be an introductory law lecture for students. And even a lecture centered on broad philosophical principles demanded a different structure than that of a formal philosophical work. To a person expecting Wilson’s lecture to read as a philosophical treatise, Wilson's organization will often appear illogical, if not backward. ${ }^{325}$ He gave two introductory lectures, one for select students and a list of worthy contemporaries, and the other just for the students. President George Washington and Vice-President John Adams attended Wilson's first lecture and Wilson’s purple prose flew to great heights, explicitly glorifying America and implicitly glorifying Washington. Both introductions stressed the importance of a law education, the need for a philosophically unique American understanding of law and a correct sensibility of law among the People at large. ${ }^{326}$ Throughout the rest of the lectures Wilson moved through various general categories of law and law-related issues in each section, moving into his epistemology in the middle of the lectures.

“A system of human nature” Wilson explained to his students “is not expected from this chair." It was, he continued "too vast for me; it is too vast for any one man, however great his genius.” For Wilson the human mind was, to some extent, an inherent mystery -- exceedingly complex, and after a point purely metaphysical. ${ }^{327}$ Yet a basic understanding of its rudimentary functions in the daily world was not outside the human

\footnotetext{
${ }^{323}$ Wood, American Republic, 567-592.

${ }^{324}$ McCloskey, “Introduction” in Works, Vol. I Wilson, ed. McCloskey, 42.

325 Ibid., 40-43.

${ }^{326}$ Smith, Wilson, 309-326; Wilson, Works, Vol. I ed. Andrews, 1-48.
} 
grasp. Indeed, it had to be grasped according to Wilson as a prerequisite for a proficient philosophical understanding of law. "In truth” Wilson declared eloquently "law can never attain either the extent or the elevation of science, unless it be raised upon the science of man.” For Wilson, the science of man was inextricably entwined with an understanding of "mind," since "every art and in every disquisition, the powers of the mind are the instruments. ${ }^{328}$ And despite his initial claim, Wilson explored the depths of epistemology quite deeply from his law chair.

As both historians Jean-Marc Pascal and Mark David Hall have remarked, the Scottish common sense philosophers heavily influenced Wilson. Like them Wilson rooted his epistemological and moral thought in the concept of a commonly held intuitive sense of morality. In a section of lecture titled "Man, as an Individual” Wilson most visibly reveals the common sense influence on his thought. ${ }^{329}$ He rejected the precepts of men that he called "the ideal philosophers," who argued the inability of the human mind to perceive anything but ideas and questioned the existence of anything outside the mind. Human perception could and did perceive external objects, said Wilson, and the contrary assumptions of the "ideal philosophers" from Descartes to Hume were untenable.

Yet, perception was not only an impression of an external stimulus upon the mind but also the intellectual apprehension of the stimulating object. Three kinds of perception existed according to Wilson. Perception of external objects via the five senses was the most obvious. "Contemplation” was another type of perception, by which a person perceived internal, intellectual objects; that is ideas. The third, and perhaps most

\footnotetext{
${ }^{327}$ Wilson, Works, Vol. I ed. Andrews, 210.

${ }^{328}$ Ibid., 207.

${ }^{329}$ Hall, Political and Legal Philosophy, 68-89; Pascal, Political Ideas, 48-152; Wilson, Works, Vol. I, 206252.
} 
important type of perception to Wilson (certainly the most fundamental) was moral perception. Moral perception apprehended the laws of God. This perception was intuitive or "self-evident" in nature and was immune to demonstrative or logical proofs. "Laws may be promulgated by reason and conscience, the divine monitors within us" declared Wilson. A primal understanding of very basic truths was "engraven by God on the hearts of men ... the promulgator as well as the author of natural law." ${ }^{330}$ An example of a self-evident truth would be the tautological statement that material existence exists. Another self-evident truth was the inalienable human rights to life and liberty. ${ }^{331}$ But some inconclusive historical evidence might be found for the general notion of selfevidential and universal truths. Wilson cited fundamental moral precepts common to most civilizations during most periods of time, such as the assumption that the majority of what was sensed was real, or that general moral concepts and human desires could be commonly found represented in every language. ${ }^{332}$

Yet, the moral law of God was general in its command. Though the human "heart" or intuitive perception might inform humanity of general precepts it did not inform human beings on how to apply those general precepts within their specific situation. Neither did divine law compel obedience. Human beings possessed free wills and the power to reason (more examples of self-evident truths) and people attempted reason to extrapolate and apply God's general law to their specific and ever-changing situations. All human beings possessed the intuitive perception equally, but not all would choose to follow God's law or had an equal ability to reason. Poor reasoning or judgment corrupted the application of God's law or even created fictions that caused

\footnotetext{
${ }^{330}$ Wilson, Works, Vol. I ed. Andrews, 58.

${ }^{331}$ Wilson, Works, Vol. I ed. McCloskey, 240-242; Wilson, Works, Vol. II ed. McCloskey, 587-598.
} 
humanity to doubt the veracity of the intuitive laws. Proper reason and obedience to the "self-evident" was the root of good in the world while poor reasoning was the intellectual root of evil and corruption in the world. Wilson thought that as civil society advanced in its morality the less likely that society would fall into error. But if a society fell into error it would suffer from social or spiritual diminution -- again, history offering its evidence. That diminution might be evident in either the extremes of anarchy or tyranny. ${ }^{333}$

The people of the United States had achieved a great advance in the progression of civil society during their Revolution, according to Wilson. The travails of American Whig opposition during the Imperial Crisis of the 1760s and 70s and then the Revolution itself had allowed, or perhaps pushed, Americans to discover the great truth of contemporary popular sovereignty. Forced to focus on certain self-evident truths, and to reject old perversions of reasoning Americans had discovered the moral imperative that all legitimate Earthly power had to be derived from the People at large.

"Sovereignty," the idea that there could only be one highest power in any civil society, was a natural law. Like the source of the Nile River, analogized Wilson, philosophers had long searched for the source of sovereign power. But all had either oversimplified the issue or clung to pre-extent assumptions so closely that their reasoning corrupted the idea of sovereignty or failed the realization of its true source. And Wilson hypothesized that the corruption of the idea of sovereignty lay at the root of the Imperial Crisis that necessitated the Revolution; the corrupt worldview turned into corrupt political assumptions that misled British policy. ${ }^{334}$

Wilson covered some of the least appreciable concepts of sovereignty through

\footnotetext{
332 Wilson, Works, Vol. I ed. Andrews, 105-153, 247-252

333 Ibid., 95-125, 157-158.
} 
history in his lecture on "Law and Obligation." The centerpiece of the lecture was his definition of law. In his basic definition of law Wilson conjoins elements of legal commentators William Blackstone and Richard Hooker. From Blackstone, Wilson drew the concept of the law as a rule. As such it was "an instrument...distinguish(ed)...from a sudden, or transient, or particular order (command)...and to denote that it carries along with it a power and principle of obligation. ${ }^{\text {335 }}$ But why that obligation existed, and from where law derived its authority was a point of disagreement between Wilson and Blackstone. Wilson also appended to Blackstone’s “rule of action” what Wilson considered to be Hooker's "fuller and stronger conception of law." Law, according to Hooker and Wilson "assigns to each the kind, that it moderates the force and power, that it appoints the form and measure of working." Wilson's preference for the less brutish, more utilitarian definition of law is telling. He wanted to think of the law as a constructive tool in its own right, not just a curmudgeon of the powerful. ${ }^{336}$

Wilson turned then to the central issue on his mind -- the nature of morally legitimate authority -- the proper source of sovereignty. Blackstone had continued in his definition of law to say that the "rule of action" was "prescribed by some superior, and which the inferior is bound to obey.” Wilson railed "A superior!”

Let us make a solemn pause-Can there be no law without a superior? Is it essential to law, that inferiority be involved in the obligation to obey it? Are these distinctions at the root of all legislation? ${ }^{337}$

To all of these questions, in Wilson's analytical, drawn-out way, he answered "no," at least in regard to human law.

\footnotetext{
${ }^{334}$ Ibid., 73, 160-161.

335 Ibid., 54-55.

${ }^{336}$ Ibid., 55.

${ }^{337}$ Ibid., 59.
} 
Two approaches to thinking about superiority existed according to Wilson: either superiority derived from power alone or superiority derived from a combination of power and moral right. In other words, either superior authority was right because of might alone, or it was right for reasons distinct of the power that made it effective. Wilson rejected the first "strange" position out of hand, denying that power in and of itself granted any special right. Governors who ruled by strength alone had no greater or lesser right to rule than the right of a People who could muster enough strength, to rebel against their governance. The position was strange and unacceptable because it involved no real sense of obligation and was inherently dangerous to liberty. Wilson added, "Bare force, far from producing obligation to obey, produces an obligation to resist.”338

Wilson preferred the second general position. But in many instances thinkers who, likewise, took up the moralistic position fell into an equally damaging set of errors, or had been erroneously interpreted. To "superiority of power" they had "superadded pre-eminence or superior excellence of nature.”339 Dionysus of Halicarnasus, Cicero, and Aristotle (according to some interpretations that Wilson found dubious) had all fallen into this error of political thinking that the most virtuous ought to rule. ${ }^{340}$

The philosophical position of rule by the most virtuous was practically untenable, claimed Wilson. "How is excellence to be rated or ascertained?” Wilson queried with an implicative question. No objectively satisfactory way existed, neither was there any individual or group objective or all-knowing enough to make a sufficiently trustworthy judgment. Even if it was not a virtual impossibility, Wilson continued that few would be all virtuous -- there would be gradations of excellence. Was "there to be a gradation of

\footnotetext{
${ }^{338}$ Ibid., 62-63.

${ }^{339}$ Ibid., 63-64.
} 
law as well as excellence?” No, all would be confusion. ${ }^{341}$

Some had tried to overcome the problem of determining the superior right to rule by two other distinctive means. One line of thought, derived from Pauline biblical text and culminating more contemporarily in the work of Jean Domat, claimed that rulers -monarchs in particular -- had been given their positions by God and ruled by divine right. God had chosen those most appropriate for his own designs, which was always for the good of humanity. Wilson scoffed at Domat's logic, saying no evidence supported his assertion; indeed, princes had often been found destructively inept. Quoting a commentator during the reign of Charles II, Wilson quipped that "the greatest part of mankind" had not "come into the world with saddles on their backs and bridles in their mouths." Neither had a "few" been born "ready booted and spurred to ride the rest.” And it was no surprise, Wilson continued, that such an absurd doctrine of "superiority" would be embraced by men of pride, and that such an "inverted way of teaching and thinking" would turn "kings into tyrants, without knowing or even suspecting that they are so.”342 Another way of overcoming the moral problem of the right to rule under the precept of superiority was through a theory of prehistoric social contract. Wilson returned to William Blackstone's Commentaries On the Laws of England. Blackstone, like John Locke, thought that society had come together for mutual protection and instituted government for self-preservation. The institution of governance involved a contract between those who would be ruled and those who would rule: those who would submit and those who would legislate in superiority. The product of the contractual relationship was civil society through law. Wilson declaimed Blackstonian doctrine with horrific

\footnotetext{
${ }^{340}$ Ibid., 64-67.

${ }^{341}$ Ibid., 66.
} 
imagery. "What is left the people?” Wilson asked. "Nothing. What are they? Slaves. What will be their portion? That of beasts -- instinct, compliance, and punishment.” Wilson was also happy to point out an inconsistency in Blackstone’s historicism.

Blackstone had made superiority a requirement of law, yet he envisions a state of natural society authoritatively legislating a contract in which the much vaunted superior is itself constructed. ${ }^{343}$

Wilson could not accept any of these solutions for superiority above, or even the necessity of superiority in the making of laws, for three basic reasons. First, the very notion of superiority always “contained the germ of...the divine right...to rule.” As such it was impious, presupposing a single person or group as wielding the authority of a demigod over the human race. ${ }^{344}$

Second, the theory of superiority, particularly as proponents of rule by excellence in virtue and contract theorists envisioned it, inverted the order of things. Their doctrines made government the end of society, but the truth was, according to Wilson, that advancement in civil society was the end of government. ${ }^{345}$ Wilson lamented,

How often has the end been sacrificed to the means! Government was instituted for the happiness of society: how often has the happiness of society been offered as victim to the idol of government! Let government -- even the constitution, be...the handmaids; let them not be...the mistresses of the state (civil society). ${ }^{346}$

Jean Barbeyrac had said that society was the "scaffolding" upon which the "building" of government was constructed. The reverse was true. ${ }^{347}$

\footnotetext{
${ }^{342}$ Ibid., 66-68, 70-72.

343 Ibid., 73-79, 165-167.

${ }^{344}$ Ibid., 84, 88.

345 Ibid., 68-69, 270-271.

346 Ibid., 271.

${ }^{347}$ Ibid., 69.
} 
According to Wilson, two general kinds of society could be understood: natural society and civil society. Human beings were inherently social animals, began Wilson in his lecture "Of Man, As a Member of Society.” He rejected the egoist principle that human beings were wholly motivated by selfishness. Self-love was a real and primal force, but sociability was also an equally primal force of its own, not a mere derivative of self-love. Human beings had always socialized, at least in loose groups. It was this loose socialization that Wilson called "natural society." Civil society or the "state" occurred when a group entered into a mutual, collective contract. "These engagements are obligatory, because they are mutual," he argued. And so the state was "a complete body of free persons, united together for their common benefit, to enjoy peaceably what is their own, and to do justice for others." The implicit result is "an artificial person," in "a state of natural liberty" with other civil societies. In that "person” the incorporated "wills and power of all the members (will) be united in such a manner, that they shall never act nor desire but one and the same thing, in whatever relates to the end, for which the society was established.”348

One of the best reasons for the formation of civil society (and eventually government), aside from base preservation, was the enhancement of liberty. Civil society lessened some of humanity's natural liberties but enhanced other liberties by restraining the actions of other humans. Wilson was optimistic, believing that there could be and ought to be a net gain of liberty in the development of civil society. In "a natural state" claimed Wilson, humanity would "enjoy less liberty, and suffer more interruption and inconvenience" than in a properly constructed civil society, because "every other individual would act uncontroulled by others.” In other words, anarchy was its own kind

348 Ibid., 138-139, 258-273. 
of tyranny. ${ }^{349}$

What was most important to Wilson was that civil society pre-dated civil government. Government was a construct of civil society and part of civil society once constructed, but unlike other political thinkers, for Wilson government was not essentially necessary for civil society to exist. So for Wilson, change in government did not have to mean the dissolution of civil society as it did for other thinkers, and the American Revolution offered Wilson his own best evidence. Government was functionally necessary, however, for the prolongation and "perfection” of civil society, particularly as the society grew and became more complex. "Without government, society, in the present state of things, cannot flourish; far less can it reach perfection.” And so the purpose of government was to aid civil society in its own preservation and advancement, and ultimately therefore, in attaining the goals to which a civil society might properly aspire. Government was a utility, an instrument of a civil society that was the People at large, bound together by a web of orderly and respectful community relationships. ${ }^{350}$

The final reason that Wilson accepted no doctrine of right to rule by superiority is that it was practically contrary to the manifestation of liberty. The American concept of liberty, one that Wilson wholly embraced, was inseparable from what modern civil libertarians might call positive rights -- the right to be represented and to be ruled by some kind of consent. Obligation was not the result of superior power over an inferior, whether defined by brute force, a supposed excellence or an impious claim to divine support. After showing the logical inconsistencies and dangerousness of all these models

349 Ibid., 344, 347-348.

350 Ibid., 343-348. 
of obligation through superiority, Wilson proclaimed that obligation to human authority can only be established through consent. Both an individual's obligation to legislative and common law authority derived from an implicit consent to them, extrapolated from the explicit consent to membership in the civil society. ${ }^{351}$

But according to Locke, Puffendorff and Barbeyrac, the People had already transferred their sovereign power to the governments that they formed. ${ }^{352}$ "I see no necessity for it” raked Wilson.

I see no propriety in it: it is derogatory...from the genuine principles of legitimate sovereignty, and inconsistent with the best theory, and the best exercise too, of supreme power. ${ }^{353}$

The power given to the government was purely functional, not the sovereign power. And in America at least, a "free state, such as ours, the sovereign or supreme power resides in the people.”354 Blackstone had argued that the legislative power was (and had to be) the sovereign power in any state. Wilson convincingly argued the contrary by using historical examples from British and recent American history. Even when a legislature was not considered the sovereign its laws could be obligatory and effectual. ${ }^{355}$

The People at large in the United States could be trusted to rule. Though not all could reason well all had an intuitive sense of right and wrong, so that if a majority of Citizens thought a general principle correct or the character of a person sufficient to hold office, their judgment could be trusted. Out of necessity it would have to be the majority that actual exercised the sovereign power of the whole. Mistakes could be expected, but the majority, particularly one drawn from a large populace could be trusted to have good

\footnotetext{
${ }^{351}$ Ibid., 88-91, 180-185, 277. Also see Reid, Concept of Liberty.

${ }^{352}$ Wilson, Works, Vol. I ed. Andrews, 68-69, 165-166.

353 Ibid., 167.

354 Ibid., 136.
} 
judgment in relation to their self-preservation and the preservation of the larger society (in which they had more vested by definition of being the majority.) The human heart was its own divine oracle receiving general principles, and the more people who thought a moral position to be correct the less likely the moral position was to be incorrect -- the less likely it was being corrupted by poor reasoning. Wilson's political cosmology juggled ideas of divine will, probability in good judgment and democracy. ${ }^{356}$

Yet, a majority (perhaps even a whole society) could hypothetically become corrupt, but apparently for Wilson, the people of the United States were sufficiently virtuous to healthfully govern themselves. The fact that sovereignty resided in the People at large and was to be exercised by the majority did not mean that morality was subjective, prostrated to the will of the majority. An objective morality commanded for Wilson -- a law of God. Popular sovereignty itself was a valid derivative of that law, a law perceptible by the intuitive sense. But sovereignty simply gave a supreme political power over Earthly human affairs -- moral legitimacy for political preeminence, but not moral or social omnipotence. God's general law was still higher and demanded obedience, even of the majority. The inalienable rights of humanity, including life, liberty, obligation by consent, free immigration, to name but a few, formed part of that law. The majority had no moral right to contravene God's law and in fact had the prime responsibility of determining it and realizing it on Earth. No human intervention ought to exert itself, denying the will of the majority in a civil society, but if the majority did contravene God's law they could expect a diminution in their civil society. The laws of nature were another conduit of God's law. Nature would insure the diminution of an

\footnotetext{
355 Ibid., 160-187.

${ }^{356}$ Ibid., 99-126, 277, 375.
} 
immoral society through tyranny, civil war, and anarchy. ${ }^{357}$

In his lecture, “Of Government,” Wilson made a startling claim for a Whig writer of eighteenth century political philosophy. He suggested that of all forms of government, monarchy was probably the first because it was the simplest. ${ }^{358}$ The oft held notion that antiquity of practice was concurrent, at least loosely, to primal truths was abandoned. The historicism of Thomas Paine, for example, spoke of the first government as being some kind of direct democracy. Monarchy was a later corruption. Like Paine, Wilson envisioned communities coming together under their own free compunction and organizing without monarchs. ${ }^{359}$ The difference is, for Wilson, that was not “government.” Community law and therefore communal governance could and did exist, at some pre-historic point, without institutional government. And admitting that monarchy was first of all officiated governments was of no danger within the Wilsonian doctrine because of how progress fit into Wilson's moral and political matrix of thought. $^{360}$

Government, like anything else in civilization and of humanity, was in a constant state of either advancement or devolution. Or as Wilson put it, "perfected” or “degraded.” The application of God's law required variation in varying situations and the human ability to realize those laws might improve as human consciousness and civilization improved. ${ }^{361}$ Wilson maintained that all "the works of human invention are progressive:"

\footnotetext{
357 Ibid., 99-101, 136, 245-247; Ibid., Vol. II 149. For Wilson’s general classes and “species” of law see Wilson, Works, Vol. I ed. Andrews, 91-93.

358 Ibid., Vol. I, 349-352.

${ }^{359}$ Paine, Common Sense, 2-5.

${ }^{360}$ Wilson, Works, Vol. I ed. Andrews, 343-381.

${ }^{361}$ Ibid., 369, 377-381.
} 
And frequently are not completed, till a slow and lengthened series of gradual improvements, remotely distant from one another both in place and time. To the theory and practice of government, this observation is applicable with...peculiar force. If the discoveries ....are difficult and slow, how much more arduous must it be to obtain, in practice, the advantage of those discoveries! ${ }^{362}$

In other words, it was one achievement to conceptualize a right political principle, quite another to understand how best to apply it. The American Revolution had facilitated a rapid advance in both principles and applications. Americans had not only discovered the true root of sovereignty but had experimented with its realization in politics and government. ${ }^{363}$ Wilson’s implication was that monarchy, as a governmental institution, was antiquated and unworthy of a politically advanced people.

The sociopolitical discoveries of Americans, or their factual corroboration of what was before mere shadowy theory, was multiplicitous according to Wilson. Again, government was itself only a tool, essentially devised to advance and stabilize civil society. And civil society was a tool to promote and secure survival and human liberty. But it was not only life and liberty that civil society and government were meant to promote and secure. In a more general sense, civil society existed to facilitate human happiness which ultimately required human progress in mental processes, knowledge, morality, society, economics, the arts and government. And for Wilson progress was not a morally neutral concept that only denoted a rapid and brute increase in resources and utility. Progress was a moral idea that denoted a qualitative increase in right versus wrong. As such, progress described the proper velocity of civilization: the drive of civil society to its moral goals.

In his lecture "Of the Law of Nations," Wilson declared that God vested the

${ }^{362}$ Ibid., 369-370. 
People at large of every state with the supreme power, and therefore supreme obligation, "for the happiness of each, and for the happiness of all."364 The civil state had general functions discernable by its nature and purpose. It was, "in general, the duty of the state to preserve itself" and "its members." And it had the "right, and is under the obligation" to do all that was necessary, not contravening higher moral laws, to achieve that goal. ${ }^{365}$ It was the "right, and generally is the duty," according to Wilson, of the state to do numerous general acts. Wilson's list is long and tells a tales of an Enlightenment mind, both pragmatic and highly moralistic. Of his list, three hold the highest ground along with self-preservation: happiness, justice and progress. ${ }^{366}$

"Happiness is the center, to which men and nations are attracted: it is therefore the duty of a nation to consult its happiness," Wilson told his students. "The arts, the sciences, philosophy, virtue, and religion, all contribute to happiness, all” he continued, "ought to receive the encouragement of the nation." Wilson loosely hinted at a need for a broader, more rigorous and uniform system of education, warning that "impressions that are made first, sink deepest" and what is taught will either "produce abundance of good, or abundance of evil., 367

"Justice” was another part of the "sacred law of nations.” Like any moral person, it was the duty of the state "to do no wrong or injury" and, in fact, "to contribute to the perfection and happiness of others" -- "not only forbidden to do evil” but "commanded to do good to one another. ${ }^{368}$

\footnotetext{
363 Ibid., 370-381.

${ }^{364}$ Ibid., 136, 146-148.

365 Ibid., 140-141.

366 Ibid., 140-147.

367 Ibid., 146.

368 Ibid., 147.
} 
And finally, "it is the glorious destiny of man,” Wilson had earlier observed "to be always progressive. It is his happiness, to press on towards” the future. ${ }^{369}$ Both happiness and justice rested on the ability to progress within the parameters, and according to the direction of God's law. "A nation should aim at its perfection," proclaimed Wilson.

The advantage and improvement of the citizens are the ends proposed by the social union. Whatever will render that union more perfect will promote these ends. The same principles, therefore, which show that a man ought to pursue the perfection of his nature, will show, likewise that the citizens ought to contribute everything in their power to the perfection of the state.

In order to approach perfection, or a higher refinement, citizens should resist "everything, which would...retard the progress of the state" and "acquire everything, without which its perfection cannot be...obtained. ${ }^{\text {} 370}$

The federal Constitution was a progressive plan of government, not only because it had advanced the understanding and application of political truth but because it facilitated the progress of the civil society -- fulfilling the purpose of government. It facilitated progress by adhering the political process to the broader civil society as closely as possible.

"Representation is the chain of communication between the people and those, to whom, they have committed the exercise the powers of government," declared Wilson in his lecture "On the Legislative Department.” And the government under the 1787 federal Constitution was the first government in post-Antiquity to be "founded solely on representation” of the rightful sovereign, the People at large. ${ }^{371}$

\footnotetext{
369 Ibid., 126.

370 Ibid., 146.

${ }^{371}$ Ibid., Volume II, 7-11.
} 
Both the House of Representatives and the Senate represented the People, though "some have considered the senators as...representing the sovereignty...of the several states. While the members of the other house immediately represent the people.” But such an opinion was "founded" in the fallacious doctrine "that the legislative power is the supreme power of the state.” Wilson vehemently reiterated, “The supreme power I showed to reside in the people." "The people have delegated to the several legislatures" he continued, "the choice of senators, while they have retained in their own hands the choice of representatives. ${ }^{372}$

The Presidency too, was rooted in the representative principle. Wilson, always eager to take another jab at Blackstone, pointed out that Blackstone had purported that the Saxons had originally elected their rulers but switched to hereditary succession because "dear-bought experience ... evinced the convenience." "If elective title is a distemper in the body-politic” quipped Wilson incredulously, perhaps to the amusement of his students, "the history ... of England would (suggest) that a hereditary title is a remedy still worse than the disease.”373 Whatever "intrigues ... cabals ... tumults, and convulsions" might be produced by the "election of our first magistrate, are avoided" by making the election mediate rather than immediate -- through the use of electors.

Moving through the various duties and powers of the chief executive Wilson came to the pardon power and made an interesting observation, again counter-arguing Blackstone. Blackstone had maintained that "the power of pardoning is a power incommunicatable to the democratical species of government.” Contrarily, Wilson spoke of the American experience. "The best and purest of all" governmental species was "the

\footnotetext{
372 Ibid., 26-27.

373 Ibid., 61-63.
} 
democratical," being defined as "that, in which the supreme power remains with the people." And it "is capable of being formed...in such a manner, as to exclude the inconveniences, and to secure the advantages of all the others (species of government.)" It was a "principle of democracy...that the law is higher than the magistrate...the constitution is higher than both...and the people (are) higher than all three.” The pardon was perfectly compatible with democracy because it was simply another possible governmental function that the people at large had delegated, as it happened, to the President. ${ }^{374}$

Though the Judiciary was not elected, the principles of representation and rule by consent penetrated even that branch of government. Judges sat during good behavior, which meant that they might be removed by the representatives of the People if they violated the People‘s trust. But more importantly, the common law bound and limited the judiciary. Wilson pointed out in his lecture "Of Juries" that jurors "must decide for law as well as fact” in the eighteenth century. It was an attribute of jurisprudence that Wilson whole-heartedly embraced, particularly in criminal cases where the consequences of conviction would be the heaviest. ${ }^{375}$ "The sentiments of the majority shall govern" after all "is...the general rule of society." And juries were representatives of the broader civil society. ${ }^{376}$ Because juries could interpret the law, they could direct its progress. The process by which common law came into existence and changed involved the People at large. It was only the broad acceptance or rejection of certain legal principles by multiple generations of the People that gave common law its force and existence through tradition. So, common law was a conduit of popular sovereignty, much like political representation

\footnotetext{
374 Ibid., 72-73.

${ }^{375}$ Ibid., 219-223.
} 
itself. $^{377}$

The realization of sovereignty was important for progress because the exercise of sovereign power by the People, through representation and governance by consent, gave them the highest power to move the government in "the true line of public liberty and happiness.”378 But the American Constitution went one step further still. The sovereign People of the United States held the power to amend their constitution through a plausible civil process whenever they chose to do so. As such, the United States Constitution related to the People "as clay in the hands of the potter...to improve...refine...and finish...as they please.” That was not to say that the people would often amend their constitution, because they probably would not. Wilson did not think that the people would change their government fundamentally "without a proportioned propelling cause.” But that government would eventually have to be altered by the People was inevitable as civil society changed, hopefully for the good. To place the amendment power in some other body would have been an invitation to tyranny; allowing for no amendments at all would produce “mistakes and mischeifs of...different kinds” including “giddy inconsistency...unthinking rashness (and) unmanly languor.” But no such mistakes had been made in forming the United States Constitution. The principles of popular sovereignty had been realized and allowed America "her preservation, her happiness, and her perfection.”379 And humanity’s “own perfection and happiness” was the divine purpose of human government. ${ }^{380}$

Wilson's United States was a progressive state, guided by a free and sovereign

${ }^{376}$ Ibid., 170, 203.

${ }^{377}$ Ibid., Vol. I, 423-459. See also Hall, Political and Legal Philosophy, 121-122.

${ }^{378}$ Wilson, Works, Vol. I ed. Andrews, 344-377.

${ }^{379}$ Ibid., 375-381. 
American people. The 1787 federal Constitution was their chief political and legal instrument of limited government and sociopolitical liberty.

\section{CHAPTER VIII}

\section{CONCLUSION}

Neo-Whig interpretations have dominated the historiography of the American Revolution for better than thirty years, but the conspiratorial sensibilities of the older materialist scholars have not been entirely abandoned. Some historians, while accepting the integrity of much of what the Revolutionary generation said, have nonetheless claimed to detect a cabalistic deceit among the American elites of the era.

Historian Gordon S. Wood had a particularly untrusting view of the federal Constitutional framers. The framers used Revolution era concepts, according to Wood, twisting populist ideas to legitimize the aristocrat-friendly government that their distrust of the people demanded. As historian George M. Dennison later described Wood's opinion, "Federalists transformed a viable revolutionary tradition into a rhetorical facade to maintain a system of aristocratic politics. ${ }^{\text {381 }}$ An eighteenth century anti-federalist could not have said it better. And more recently the historian Edmund S. Morgan has taken a broadly suspicious view of popular sovereignty and its historical application. The elite revolutionaries of the English Civil War and the American Revolution used the concept of popular sovereignty to justify their rebellion and usurpation of power. It was a

\footnotetext{
${ }^{380}$ Ibid., 99.

381 Dennison, “Revolution Principle” in The Review of Political Science, 39 (1977): 183; Wood, American
} 
tool, according to Morgan, to gain the support of the masses who had the numbers necessary for successful rebellions. But once embraced by the unwashed masses, the "fiction" of popular sovereignty had to be perpetuated in the new order. The illusion of control had to be given to the populous through various governmental mechanisms like voting for representatives (constituency/representation itself being a mere fiction) and popular ratification that supposedly realized popular sovereignty. ${ }^{382}$ Through this historical lens the Founding Fathers become like the pigs in George Orwell’s Animal Farm whom, in order to secure their preeminence, perverted the ideas of the revolution that brought them to power. ${ }^{383}$

If the professional lifeblood of the historian is the words of the past, then critical thinking is the heartbeat of their interpretations. Some of the challenges to the profession are implicit in its directives. A desire to interpret human record may slide easily into an uncritical acceptance of a record's holistic veracity. And a critical sensibility may devolve into a prejudicial cynicism. However much the less-than-sparkling interpretation of the Wood/Morgan stamp is or is not deserved by the American Revolutionary generation will continue as a contentious question.

Yet what is certain, after viewing Wilson's efforts during the constitutional conventions of 1787 and 1790, and the contents of his law lectures, is that such mistrust has no veracity in interpreting the ethos of James Wilson. ${ }^{384}$ For Wilson, popular sovereignty and the instrumentality in government and law that it required, was no mere

Republic, 506-517, 562-564.

${ }^{382}$ Such is the thesis of Edmund S. Morgan in his book Inventing the People. Also see Read, Power vs. Liberty, 97-98 for another historians analysis of the Wood/Morgan thesis.

${ }^{383}$ See George Orwell, Animal Farm: A Fairy Tale (New York: Harcourt, Brace \& Company, 1946).

384 The historian James H. Read has made the exact same observation. See Read, Power vs. Liberty, 114115. 
contrived fiction but a fundamental truth discovered through the fiery baptism of the American Revolution.

Wilson was not without his inconsistencies. Like many of the Founders he held a domestic slave while glorifying and developing a philosophy of liberty. Though he demanded that juries were necessary in criminal trials he equivocated on their need in civil cases, and his explanation was never quite satisfactory. He thought it was sufficient to point out the impracticality of having juries in all civil cases without bothering to revisit his overall moral philosophy concerning the need for juries.

Also, Wilson placed a great deal of emphasis on the importance of intellectual development, headed one of America's earliest post-Confederation law lecture, and pronounced the need for a general understanding of law and government by the common people. The idea of public education, however, was conspicuously missing from Wilson's writings. As the historian Mark David Hall observed, Wilson seemed to have assumed that the public could learn what was necessary from observing a virtuous leadership and the equitable processes of free government. ${ }^{385}$

Yet, all human beings are full of inconsistencies and what is more interesting and important about Wilson is not his inconsistencies, but his philosophical consistencies. As a whole, Wilson's political thought is remarkably consistent and cohesive, easily blending what many historians have traditionally understood as conceptual contradictions. And reading Wilson's works, one would have a difficult time doubting the sincerity of Wilson's theories of popular sovereignty, progressive civil society and the instrumentality of law and government. His was a sincere doctrine both populist, constitutional and progressive. 
The historian James H. Read has actually criticized Wilson for being too consistent -- stubbornly doctrinaire in the face of confuting experience. As Wilson made clear in numerous speeches and in his law lectures, the majority exercised the sovereignty of the People (and perhaps pluralities when majorities cannot be formed, though Wilson never spoke of pluralities.) There was to be no non-majoritarian human check on the will of the majority. Read accused Wilson of naïveté, contrasting his faith in the People to Madison’s more "realistic" skepticism. Wilson foolishly ignored the possibility of majoritarian tyranny, according to Read, veiling his own eyes with a common sense doctrine of human morality. What made Wilson's philosophical failure more damning is not only his association with men like Madison who knew better, but Wilson's own experience as the victim of a riot. ${ }^{386}$

However, on final analysis Read’s criticism is unfair. Even Madison understood that the minority could be protected only with the assent of the majority: consenting to lawful rule through representation or tradition. Under this consideration the difference between Wilson and Madison appears to be the depth of their particular philosophical considerations, rather than the essences of them. Wilson simply peeled the conceptual onion closer to the core, and felt it more important to dwell there. Such a thought brings to the fore the next greatest difference between the thought of Wilson and Madison. The particular threats to American republicanism and liberty was viewed differently by the two men.

Read found it difficult to understand how Wilson could have continued to be the doctrinaire majoritarian that he was, following the attack of his house by what Wilson

\footnotetext{
385 Hall, Political and Legal Philosophy, 179-186.

386 Read, Power vs. Liberty, 89-114.
} 
believed to be a politically motivated mob. Wilson never put the Fort Wilson incident into conceptual perspective, not in writing anyway. He does not mention Philadelphian mobs in his law lectures. But the Wilsonian answer to Read's criticism is easily surmised. The crowd that attacked Wilson's home was not a majority, they were a scurrilous and populous minority. And if that minority had obeyed the spirit of the majority of people in the city of Philadelphia (who were not out attacking houses) the riot would never have happened. The crowd was a misinformed minority of malcontents, misled by corrupt Constitutionalist leaders.

Then there was the problem of mobs breaking out against creditor-friendly courts throughout the states in the mid to late 1780s. Many founders, it is undeniable, saw these problems as symptoms of too much democracy in the states. But Wilson did not see the problem as one of too much democracy (or it does not appear so when looking at his contributions in the Philadelphia Convention.) Wilson supported continental nationalism in 1787 because he always had been a continental nationalist. Unlike other men, he did not need fear to motivate his support for central government. And the crowd violence exercised against the governments of the states could also be rationalized as the activities of rogue minority groups within the political society. Again, Wilson did not ever write on the issue but such a rationale would make sense within the context of his overall thought.

In our post-Holocaust, post-Civil Rights movement age it may indeed seem naive to put too much trust in the majority. Read's reaction to Wilson is understandable. But Read's criticism is not wholly consistent with the material that Wilson proffered in his writings. Read claimed that Wilson never even thought of the possibility of majority 
tyranny, though most within his generation certainly did worry over it. But in Wilson's law lectures he did mention the possibility that a whole political society might be corrupted. ${ }^{387}$ And in his opening speech before the Pennsylvania ratifying convention, Wilson warned that there could be no appeal from a corrupt majority. ${ }^{388}$ These kinds of comments cannot come from a man for whom the possibility of majoritarian tyranny was beyond the intellectual horizon. Wilson did understand that a majority could hypothetically be tyrannical, though he assumed the probability of it to be slight. And the only cure for such a corruption was the providence of God acting in the flow of history. He did not think that a truly willful and constant majority could be (or ought to be) denied their will by human coercion.

The fact that Wilson never went into detail concerning majoritarian corruption and tyranny does not suggest simple-mindedness but a particular understanding of the problems of his time. The majority had not oppressed humanity in the generations immediately preceding his, or in his generation, and he did not consider it a probability in the foreseeable future. For Wilson, the problem of corruption and tyranny had always been a problem of grasping minorities and poor governance. Few people making an argument in favor of a solution to their contemporary problems will counter-argue themselves for the sake of holistically-turned future philosophers and historians. If denial of the popular will was the chief problem of Wilson's own time, why would Wilson confuse his listeners by remonstrating deeply on the hypothetical possibilities of popular tyranny? He would not and he did not.

Wilson, whether considered a naive doctrinaire or an insightful but shrewd

\footnotetext{
${ }^{387}$ Wilson, Works, Vol. I ed. Andrews, 99-101, 136, 245-247.

${ }^{388}$ Wilson, “Commentaries” in Political Essays ed. Adams, 180.
} 
polemicist, has something to offer to the modern historian and American citizen. With Wilson, the researcher can peek into the thinking of a radical American mind of the revolutionary generation. In some respects that mind was representative of the generation, while in others Wilson's thought may be considered eccentric, demonstrating the plasticity of eighteenth century radicalism (Wilson's refusal to distinguish between American republicanism and democracy comes to mind.) Either way, Wilson's thinking is suggestive and is made up of the same philosophic essentials that compose the cultural foundations of the American republic. The extent that Wilson's thought was representative of his overall generation, both inside and outside of the Revolution's elite leadership, certainly deserves more study. 


\section{REFERENCES}

Primary Sources:

Hamilton, Alexander, John Jay and James Madison. The Federalist, ed. Benjamin F. Wright. MetroBooks, 1967.

Jefferson, Thomas. The Life and Selected Writings of Thomas Jefferson, ed. Adrienne Koch and William Peden. New York: Random House, Inc., 1972.

Madison, James. Notes of Debates in the Federal Convention of 1787, ed. Adrienne Koch. New York: W.W. Norton \& Company, 1987.

Madison, James. The Papers of James Madison, ed. Robert A. Rutland. 17 Volumes. Chicago: The University of Chicago Press, 1962-1985.

McMaster, John Bach and Frederick D. Stone, ed. Pennsylvania and the Federal Constitution,1787-1788. 2 Volumes. New York: Da Capo Press, 1970.

Paine, Thomas. Common Sense. New York: Dover Publications, Inc., 1997.

Thorpe, Newton. American Charters, Constitutions and Organic Laws, 1492-1908.

7 Volumes. Washington: Government Printing Office, 1909.

Wilson, James. Selected Political Essays of James Wilson, ed. Randolph G. Adams. New York: Alfred A. Knopf, 1930.

Wilson, James. The Works of James Wilson, ed. James DeWitt Andrews. 2 Volumes. Chicago: Callaghan and Company, 1896.

Wilson, James. The Works of James Wilson, ed. Robert Green McCloskey. 2 Volumes. Cambridge: Belknap Press of Harvard university Press, 1967.

Wilson, James. James Wilson Papers, 1742-1798. Unpublished: Archives of The Historical Society of Pennsylvania.

Secondary Sources (Monographs and Literary Works):

Bailyn, Bernard. Faces of the Revolution: Personalities and Themes in the Struggle for American Independence. New York: Alfred A. Knopf, 1996.

- The Ideological Origins of the American Revolution. Cambridge: Belknap Press of Harvard University Press, 1967

Beard, Charles A. An Economic Interpretation of the Constitution of the United States. 
New York: The Free Press, 1986.

Brunhouse, Robert L. The Counter-Revolution in Pennsylvania. New York: Octagon Books, 1971.

Burnett, Edmund Cody. The Continental Congress. New York: The MacMillan Company, 1941.

Cook, Don. The Long Fuse: How England Lost the Colonies, 1760-1785. New York: The Atlantic Monthly Press, 1995.

Countryman, Edward. Americans: A Collision of Histories. New York: Hill and Wang, 1996.

Delahanty, Mary T. The Integralist Philosophy of James Wilson. New York: Pageant Press, Inc., 1969.

Foner, Eric. Tom Paine and Revolutionary America. New York: Oxford University Press, 1977.

Freeman, Douglas Southall. George Washington: A Biography. 7 Volumes. New York: Charles Scribner's Sons, 1948-1957.

Greene, Jack P. Intellectual Heritage of the Constitutional Era: The Delegate's Library. Philadelphia: The Library of Congress, 1986.

Hall, Mark David. The Political and Legal Philosophy of James Wilson, 1742-1798 Columbia: University of Missouri Press, 1997.

Jensen, Merrill. The Making of the American Constitution. New York: Robert E. Krieger Publishing Company, 1964.

Ketchum, Ralph. James Madison: A Biography. New York: The MacMillan Company, 1971.

Maier, Pauline. From Resistance to Revolution: Colonial Radicals and the Development of American Opposition to Britain, 1765-1776. New York: Norton \& Company, 1991.

McCullough, David. John Adams. New York: Simon \& Schuster, 2001.

Molho, Anthony and Gordon S. Wood. Imagined Histories: American Historians

Interpret the Past. Princeton: Princeton University Press, 1998.

Morgan, Edmund S. ed. The American Revolution: Two Centuries of Interpretation. Englewood Cliffs: Prentice-Hall Inc., 1965. 
. Inventing the People: the Rise of Popular Sovereignty in England and America. New York: Norton, 1989.

Nelson, William E. Marbury vs. Madison: The Origin and Legacy of Judicial Review. Lawrence: University Press of Kansas, 2000.

Orwell, George. Animal Farm: A Fairy Tale. New York: Harcourt, Brace \& Company, 1946.

Pascal, Jean-Marc. The Political Ideas of James Wilson, 1742-1798. New York: Garland Publishing, Inc, 1991.

Pocock, J.G.A. ed. Three British Revolutions, 1641, 1688 and 1776. Princeton: Princeton University Press, 1980.

. Machiavellian Moment: Florentine Political Thought and the Atlantic Republican Tradition. Princeton: Princeton University Press, 1975.

Rakove, Jack N. Original Meanings: Politics and Ideas in the Making of the Constitution. New York: Alfred A. Knopf, 1996.

Read, James H. Power vs. Liberty: Madison, Hamilton, Wilson and Jefferson. Charlottesville: University Press of Virginia, 2000.

Reid, John Phillip. The Concept of Liberty in the Age of the American Revolution. Chicago: The University Press, 1988. . Constitutionalism in the Age of the American Revolution (abridged). Madison: University of Wisconsin Press, 1995.

. Constitutionalism in the Age of the American Revolution. Madison: University of Wisconsin Press, 1986.

Risjord, Norman K. Jefferson’s America, 1760-1815. Madison: Madison House Publishers, Inc., 1991.

Rosswurm, Steven. Arms, Country and Class: The Philadelphia Militia and the "Lower Sort” During the American Revolution, 1775-1783. New Brunswick: Rutgers University Press, 1987.

Ryerson, Richard Alan. The Revolution is Now Begun: The Radical Committees of Philadelphia, 1765-1776. Philadelphia: University of Philadelphia Press, 1978.

Smith, Charles Page. James Wilson, Founding Father, 1742-1798. Chapel Hill: The University of North Carolina Press, 1956. 
Wood, Gordon S. The Creation of the American Republic, 1776-1787. Chapel Hill: University of North Carolina Press, 1969. . The Radicalism of the American Revolution. New York: Vintage Books, 1991.

Zobel, Hillard B. The Boston Massacre. New York: W.W. Norton \& Company, 1970.

Secondary Sources (Articles):

Adams, Randolph C. “The Legal Theories of James Wilson.” University of Pennsylvania Law Review and Law Register, 68 (June, 1920).

Alexander, John K. "The Fort Wilson Incident of 1779: A Case Study of the Revolutionary Crowd.” William and Mary Quarterly, Third Series, 31 (October, 1974).

Appleby, Joyce. "Republicanism in Old and New Contexts.” William and Mary Quarterly, Third Series, 43 (January, 1986).

Banning, Lance. “Jeffersonian Ideology Revisited: Liberal and Classical Ideas in the New American Republic.” William and Mary Quarterly, Third Series, 4 (January, 1986).

Conrad, Stephen A. “James Wilson’s ‘Assimilation of the Common Law Mind’.” Northwestern University Law Review, 84 (1989).

. "Metaphor and Imagination in James Wilson's Theory of Federal Union.” Law and Social Inquiry: Journal of the American Bar Association,13 (1988).

Dennison, George M. “The 'The Revolution Principle’: Ideology and Constitutionalism in the Thought of James Wilson.” The Review of Politics, 39 (1977).

Ireland, OS. "The Crux of Politics: Religion and Party in Pennsylvania, 1778-1789." William \& Mary Quarterly, 3rd Series, 42, No. 4 (Oct., 1985).

Jillson, Calvin C. and Cecil L. Eubanks. "The Political Structure of Constitution Making." American Journal of Political Science, 28, No. 3 (Aug., 1984).

Kenyon, Cecelia M. "Republicanism and Radicalism in the American Revolution - An Old Fashioned Interpretation." William \& Mary Quarterly, Third Series, 19 (April, 1962). 
Kramnick, Issac. "Republican Revisionism Revisited.” The American Historical Review, 87 (June, 1982).

Leavelle, Arnaud B. "James Wilson and the Relation of the Scottish Metaphysics to American Political Thought." Political Science Quarterly, 57, Issue 3 (Sept., 1942).

Pocock, J.G.A. "Between Gog and Magog: The Republican Thesis and the Ideologia Americana." Journal of the History of Ideas, 48 (April-June, 1987).

Rodgers, Daniel T. “Republicanism: The Career of a Concept.” The Journal of American History, 79 (June, 1992).

Rossum, Ralph. "James Wilson and the 'Pyramid of Government'.” The Political Science Reviewer, 6 (1976).

Thompson, E.P. "The Moral Economy of the English Crowd in the Eighteenth Century.” Past and Present, 50 (1971). 